\title{
Rodrigo Jacob
}

Engenheiro Agrônomo

\section{AVALIAÇÃO DE DOIS DIFERENTES ENLEIRADORES PARA O RECOLHIMENTO, A GRANEL, DE PALHIÇO EM CANA-DE-AÇÚCAR (Saccharum spp.)}

Orientador: Prof. Dr. TOMAZ CAETANO CANNAVAN RIPOLI

Dissertação apresentada para obtenção do título de Mestre em Agronomia. Área de concentração: Máquinas Agrícolas. 


\section{ERRATA}

$\mathrm{JACOB}, \mathrm{R}$. Avaliação de dois diferentes enleiradores para o recolhimento, a granel, de palhiço em cana-de-açúcar (Saccharum spp.). 2005. 88p. Dissertação de (Mestrado em Máquinas Agrícolas) - Escola Superior de Agricultura "Luiz de Queiroz", Universidade de São Paulo, Piracicaba, 2005.

$\begin{array}{ll}\text { Página } & \text { Linha } \\ 5 & 11 \\ 6 & 1 \\ 6 & 4 \text { e } 5\end{array}$

Todas Todas

Todas Todas

14

20

23

26

28

34

40

42

44

44

54

61

61

63

65

65

66.

69

$69 \quad 15$

67

68

70

70

5

17

22

4

3, 6

Figura

14 15 4 19 17
Onde se lê

2.1.2 A Queima de Canaviais da Operação de enleiramento Capacidades Efetiva $\theta$ Operacional e o consumo de combustível da Operação de...

w, Mw e Gw

$\mathrm{Km}, \mathrm{Kg}$ e Kcal

...Capacidades

Operacional...

4 ...ponteira da cana...

14 Tabela 3

28 ...de 0,76 EBP/t, que...

Última $\ldots$ resíduos Urbanos sólidos...

5 em 33,7Mw, SLEIMAN (1998).

$3,4,5 \quad 7,00 \times 10,5,55 \times 10$ e $0,26 \times 10$

...FORD, modelo $4 \times 2$ TDA, ...

...porcentagens de umidade...

...existente no solo...

Onde:

14,1 tha ${ }^{-1}$

Legendas da Figura 14 -Eixo $Y$ :

Eixo $X$ :

14,10 para o autor 13

Figura Legendas da Figura 15 -Eixo Y:

\section{Eixo $X:$}

Figura Legendas da Figura 16-Eixo $Y$ : 16 Eixo $X:$

$6,67,7,23$, T1E1R1

18, 34, T1E2R1

Tabela T1 e T2 p/ BIZUTI 2003

Figura Legendas da Figura 17 -Eixo Y:

\section{Eixo $X$ :}

2 ...relatório estatístico, apresenta-se...

$19 \quad 1,13$

\section{Leia-se}

2.1.2 A queima de canaviais

da operação de enleramento

Capacidades efetiva e operacional e o consumo de combustível da operação de...

W, MW e GW

$\mathrm{km}, \mathrm{kg}$ e kcal

...capacidades efetiva e operacional...

...ponteiro da cana...

Valores em porcentagem

... de 0,76 EBP. $t^{-1}$, que...

... resíduos urbanos sólidos...

em 33,7MW (SLEIMAN, 1998).

$7,00.10^{6}, 5,55.10^{6}$ e $0,26.10^{6}$

... FORD $4 \times 2, \ldots$

...porcentagens de teor de água...

...existente sobre o solo...

Sendo:

14,75 t.ha $^{-1}$

Produtividade de palhiço em tha ${ }^{-1}$

Autores.

14,75 para o autor 13

Velocidade média de enleiramento $\left(\mathrm{km} \cdot \mathrm{h}^{-1}\right)$

Tratamentos.

Teor médio de terra no palhiço (\%)

Tratamentos.

T1R1

$\mathrm{T} 2 \mathrm{R} 1$

$\mathrm{T}^{*}$ e $\mathrm{T}^{*}$ p/ BIZUTI 2003 (recolhimento por enfardamento)

Custo do recolhimento a granel em $R \$ . t^{-1}$

Autores.

...relatório estatístico mediante ao teste de Tukey, apresenta-se...

1,20 
Dados Internacionais de Catalogação na Publicação (CIP) DIVISÃO DE BIBLIOTECA E DOCUMENTAÇĀO - ESALQ/USP

\section{Jacob, Rodrigo}

Avaliação de dois diferentes enleiradores para o recolhimento a granel de palhiço em cana-de-açúcar (Saccharum spp.) / Rodrigo Jacob. - - Piracicaba, 2005

87 p. : il.

Dissertação (Mestrado) - - Escola Superior de Agricultura Luiz de Queiroz, 2005.

Bibliografia.

1. Cana-de-açúcar 2. Colheita 3. Energia de biomassa 4. Residuos agrícolas I. Título

CDD 633.61

"Permitida a cópia total ou parcial deste documento, desde que citada a fonte - O autor" 


\section{DEDICO}

Aos meus pais, Renato e Teresinha que sempre lutaram para dar aos seus filhos o melhor e sei que vibram a cada passo conquistado, o que não seria possível sem essa estrutura familiar maravilhosa, pelo carinho, amor e apoio incondicional em todas as etapas de minha vida.

À minha irmã Renata que, graças ao seu conhecimento em informática, sempre salvou esta dissertação nos meus momentos de descuido.

À Fabiana César Medeiros, minha noiva e parceira incondicional, que sempre me incentivou a dedicar-me com empenho neste trabalho.

Ao meu querido avô Jacob Jacob (in memorium) 


\section{AGRADECIMENTOS}

Ao prof. Doutor Tomaz Caetano Cannavan Ripoli, mais que professor, um amigo, confidente e o melhor orientador que alguém pode querer, que me incentivou a realizar este Mestrado, sempre abrindo as portas e acreditando no meu potencial.

Aos professores Doutor Walter Molina Junior, Doutor Casimiro Dias Gadanha Junior, Doutor José Paulo Molin e Doutor Marcos Milan, pelos conhecimentos adquiridos durante o curso.

Ao Departamento de Engenharia Rural, em especial aos colegas do curso de Máquinas Agrícolas, aos funcionários, pela amizade, estímulo e sugestões na elaboração desta dissertação.

Aos meus amigos Maurício (Paragua), Fabiana Nicoleti Franco (Antartik), Jorge Murilo Suguisawa (HC), Adolfo (Adolfinho), Alex (Telão), Cristiano (Bebê), Juliano (Brou), Luciano (Bacon), Marcos (Marcolino), Mario (Marião), pelos conselhos sempre necessários e pelo enorme carinho.

Ao Grupo Cosan, em especial aos funcionários e colaboradores, que tornaram possível a realização do experimento no campo.

A CAPES pelo auxílio financeiro prestado

À Deus e minha familia... 


\section{SUMÁRIO}

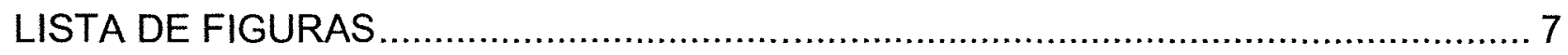

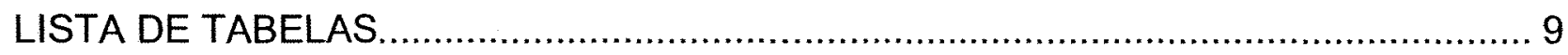

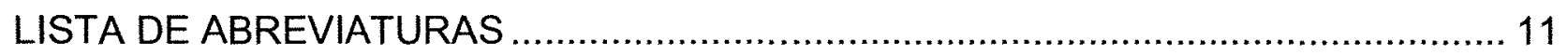

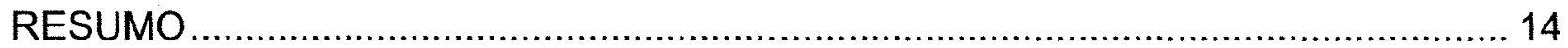

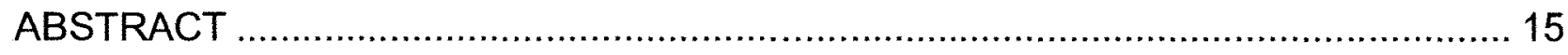

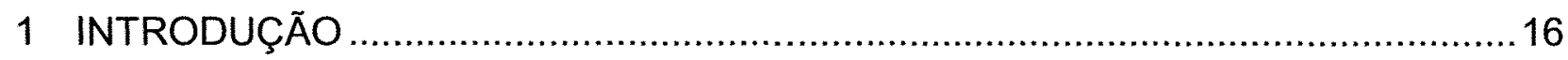

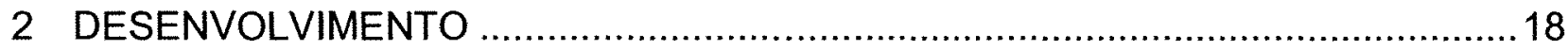

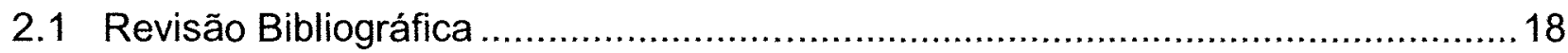

2.1.1 A cana-de-açúcar, subprodutos, produção................................................... 18

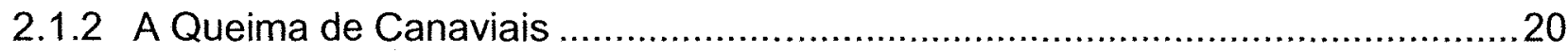

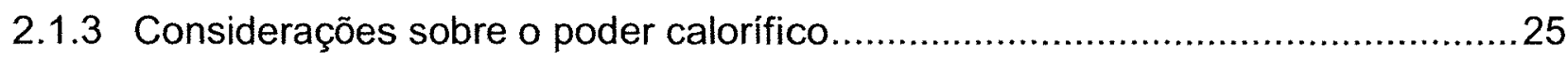

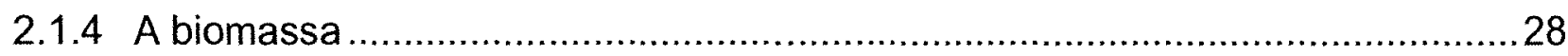

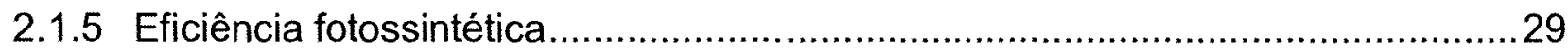

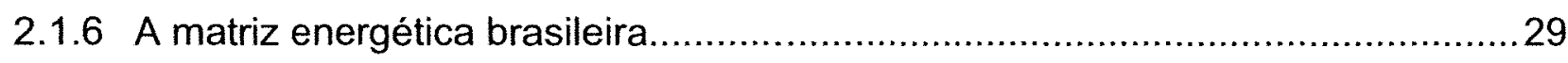

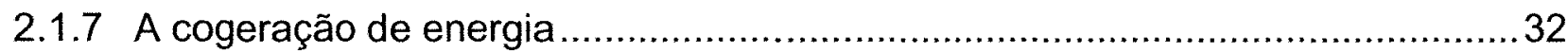

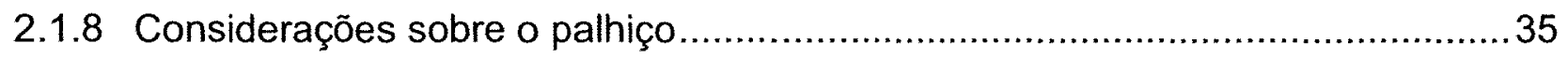

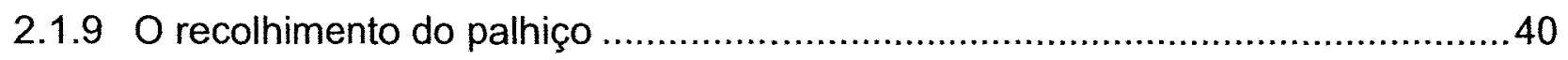

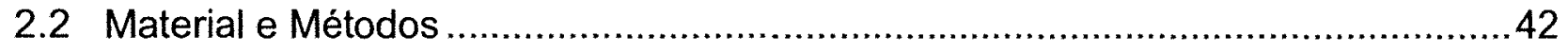

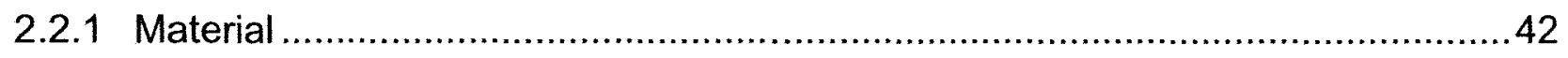

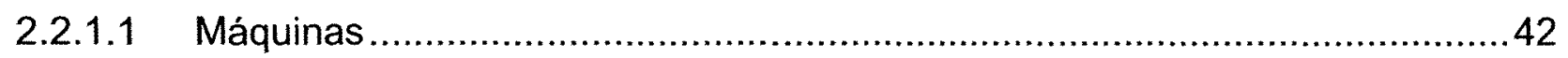

2.2.1.2 Caracterização da cultura da cana-de-açúcar .........................................42

2.2.1.3 Equipamentos de mensuração ................................................................ 42

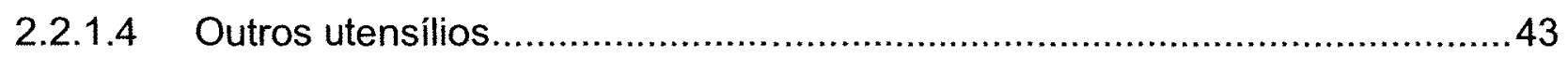

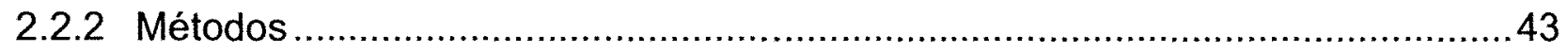

2.2.2.1 Determinação de massa, umidade e terra agregada do palhiço "in natura" e algumas caracteristicas do solo. ............................................4 44

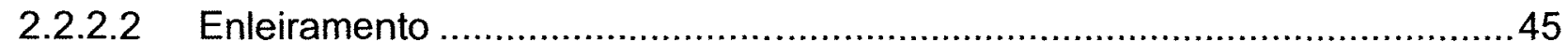

2.2.2.2.1 Capacidades efetiva e operacional e o consumo de combustível 
da Operação de enleiramento ...........................................................45

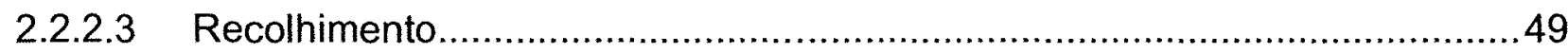

2.2.2.3.1 Determinação da transferência de massa da carreta para o trator................50

2.2.2.3.2 Capacidades Efetiva e Operacional e o consumo de combustível da Operação de recolhimento ..........................................................51

2.2.2.4 Determinação de massas de palhiço não manipuladas (perdas)

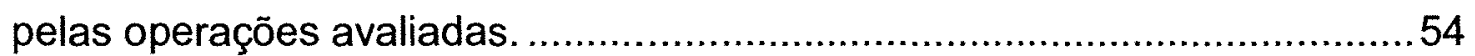

2.2.2.5 Umidade do palhiço recolhido e a de terra arrastada no material manipulado e carregado na unidade de transporte....................................56

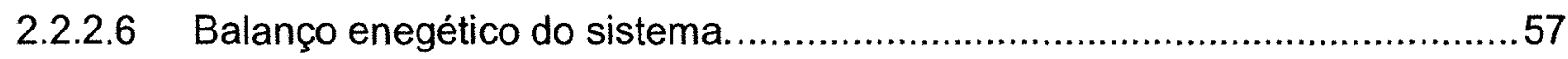

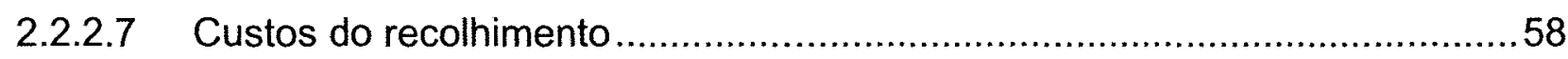

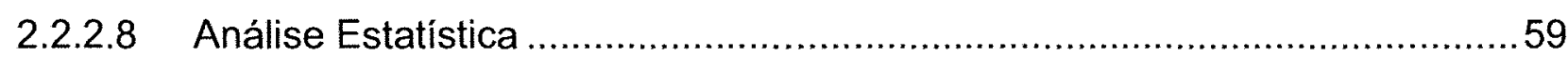

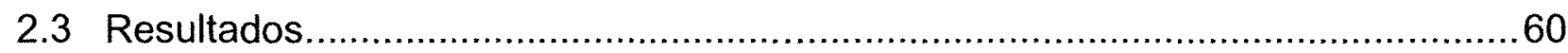

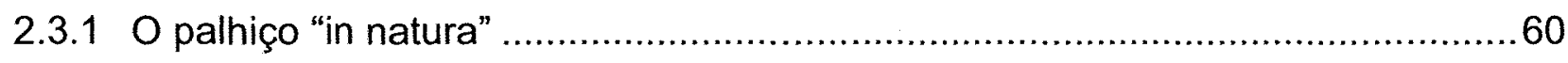

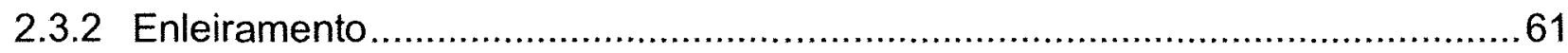

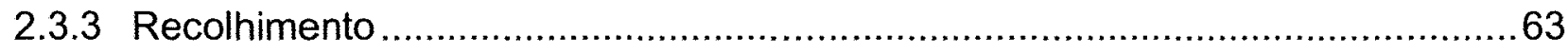

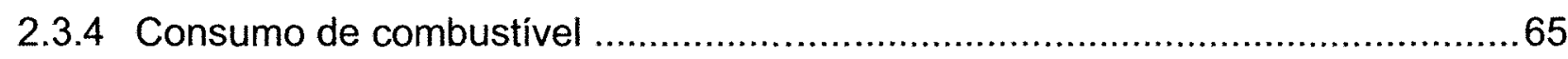

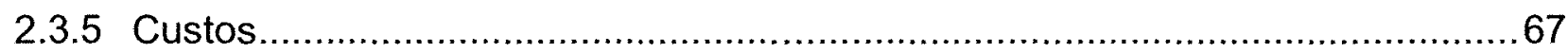

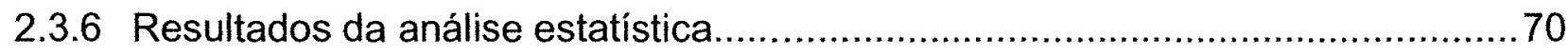

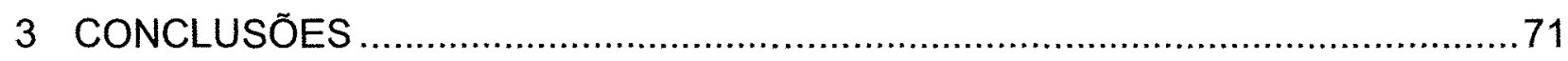

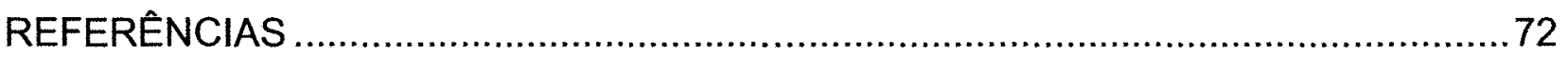

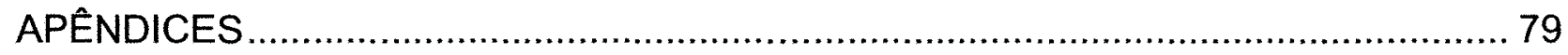




\section{LISTA DE FIGURAS}

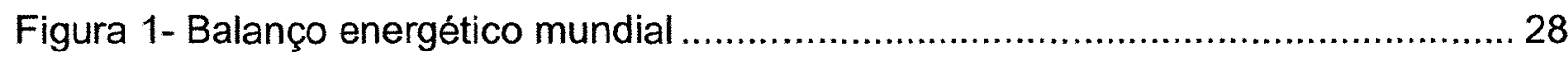

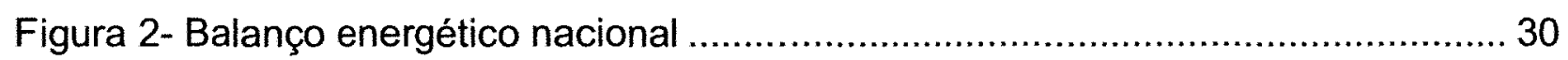

Figura 3- Potência instalada (Mw) de cogeração do setor sucroalcooleiro (1999) ........ 34

Figura 4- Origem da energia contida em um hectare de canavial (Ripoli, 2001).......... 39

Figura 5- (A) Vista traseira do ancinho marca JF; (B) Vista traseira do ancinho JF, formando a primeira leira; (C) Vista frontal do ancinho JF remontando meia leira sobre a anterior; (D) ancinho JF realizando a primeira passada; $(E)$ ancinho $D M B$ remontando uma leira; $(F)$ reabastecimento completo do tanque de combustível do trator.

Figura 6- Esquema de enleiramento onde ida e volta formam uma repetição (uma leira)

Figura 7- (A) Abastecimento para a operação de recolhimento, $(n b)=$ nivel de bolha; (B) recolhedora JF; (C) recolhimento, vista traseira; (D) recolhimento vista frontal; $(E)$ pesagem de uma repetição (2 fileiras de material enleirado).

Figura 8- (A) Utilização de guincho para separar o transbordo do trator; (B) barra de tração separada do transbordo; (C) pedaços de madeira entre os balancins e a base da caçamba 51

Figura 9- Esquema de recolhimento, onde cada repetição corresponde a duas leiras 53

Figura 10- (A) Amostragem de palhiço remanescente sobre a área e após ação do ancinho; (B) Área de $1 \mathrm{~m}^{2}$, dentro do qual recolheu-se o material remanescente; (C) Área da amostra após recolhimento; (D) amostragens de palhiço remanescente sobre a área correspondente e após a ação da recolhedora 55

Figura 11- Critério para a determinação pelas operações, para obtenção em ha., das perdas sendo: $D L$ = distância entre leiras $(m)$ e $L L=$ largura da leira $(m)$. 
Figura 12- (A) Uma amostragem do palhiço colhido e carregado no transbordo; (B) palhiço transferido para o transporte; (C) transporte coberto com tela de nylon, para deslocamento

Figura 13- (A) Abertura das laterais, por meio de pá carregadora; (B) descarregamento do palhiço; (C) deposição do palhiço sobre o local 57

Figura 14- Produtividade do palhiço "in natura", comparação obtida entre diversos autores 61

Figura 15- Comparativo entre as velocidades médias $\left(\mathrm{Km} . \mathrm{h}^{-1}\right)$ de enleiramento entre tratamentos para diferentes autores

Figura 16- Comparativo entre o teor médio de terra (\%). presente no palhiço recolhido, entre tratamentos para diferentes autores 65

Figura 17- Validação comparativa entre autores para o custo do recolhimento a granel em $\mathrm{R} \$ \mathrm{t}^{-1}$ 68 


\section{LISTA DE TABELAS}

Tabela 1- Produção de açúcar (sacas de $50 \mathrm{Kg}$ ) de 1999 até 2002 no Brasil,

Centro-Sul e São Paulo.

Tabela 2- Produção de álcool total $\left(\mathrm{em} \mathrm{m}^{3}\right)$ para o Brasil, Centro-Sul e São

Paulo.

Tabela 3- Composição do colmo e das folhas da cana-de-açúcar.

Tabela 4- Análises preliminares sobre o potencial energético da palha em

canaviais brasileiros.

Tabela 5- Resumo dos resultados obtidos por Ripoli et al. (1990a), de diversas

variáveis do palhiço de cana-de-açúcar.

Tabela 6- Situação atual do setor de energia elétrica nacional.

Tabela 7-Produção de eletricidade por fonte de geração em Gwh de 1988-1998.

Tabela 8- Produtividades do palhiço encontradas em bibliografia consultada. 36

Tabela 9- Resultados obtidos por Lopez (1987) sobre operações agrícolas envolvidas na manipulação de palhiço.

Tabela 10- Estimativa do potencial disponível em um hectare de cana-de-açúcar sem queima prévia. 39

Tabela 11- Comparação entre palhiço, bagaço e casca de arroz. 40

Tabela 12-PCS médios encontrados nos constituintes do palhiço. 57

Tabela 13- Caracterização do palhiço "in natura" 60

Tabela 14- Operação de enleiramento, resultados de velocidade de deslocamento, de capacidades efetiva e operacional, consumo de combustivel e massa de palhiço enleirado.

Tabela 15- Análise entre máquinas enleiradoras, comparativo médio entre autores.

Tabela 16- Operação de recolhimento, resultados de velocidade de deslocamento, capacidades efetiva e operacional, teor de umidade e terra contida no palhiço sobre o transporte 64

Tabela 17- Comparativo entre autores na operação de recolhimento. 64 
Tabela 18- Consumos de combustível nas operações de enleiramento, recolhimento, transporte e descarga do palhiço na usina. 66

Tabela 19- Comparativo de consumo de combustível entre autores...........................67

Tabela 20- Desempenho econômico das operações envolvidas no sistema. ................67 67

Tabela 21- Custo da energia, na forma de palhiço, colocada na usina.......................69 69

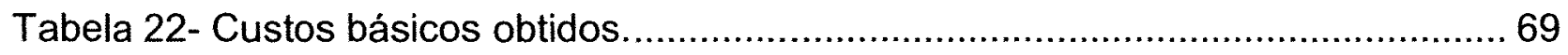

Tabela 23- Resumo dos resultados obtidos na análise estatística das principais variáveis analisadas ao nível $5 \%$ de significância.................................... 70 


\section{LISTA DE ABREVIATURAS}

$\mathrm{AE}\left(\mathrm{m}^{2}\right.$.repetição $\left.{ }^{-1}\right)=$ Área enleirada por repetição.

$\operatorname{AR}\left(\mathrm{m}^{2}\right.$.repetição $\left.{ }^{-1}\right)=$ Área de recolhimento.

AT $\left(\mathrm{m}^{2}\right.$.repetição $\left.{ }^{-1}\right)=$ Área do tratamento.

BETS $(\%)=$ Balanço (eficiência) energético do sistema .

CA $\left(\right.$ L. $\left.h^{-1}\right)=$ Consumo aferido.

$\operatorname{CDP}\left(\mathrm{R} \$ \mathrm{t}^{-1}\right)=$ Custo do descarregamento do palhiço, a granel, na usina.

$\mathrm{CEE}_{1}$ (ha. $\left.\mathrm{h}^{-1}\right)=$ Capacidade efetiva de enleiramento.

$\mathrm{CEE}_{2}\left(\mathrm{t} \cdot \mathrm{h}^{-1}\right)=$ Capacidade efetiva de enleiramento.

CEP $\left(R \$ . t^{-1}\right)=$ Custo do enleiramento do palhiço.

CEPU $\left(R \$ . E B P^{-1}\right)=$ Custo da energia contida no palhiço, posto na usina.

$\mathrm{CER}_{1}\left(\mathrm{t} \cdot \mathrm{h}^{-1} ;\right)=$ Capacidade efetiva de recolhimento.

$\mathrm{CER}_{2}\left(\right.$ ha. $\left.\mathrm{h}^{-1}\right)=$ Capacidade efetiva de recolhimento.

CMEE (L.repetição $\left.{ }^{-1}\right)=$ Consumo médio efetivo no enleiramento.

CMOE (L.repetição $\left.{ }^{-1}\right)=$ Consumo médio operacional no enleiramento.

$\mathrm{COE}_{1}\left(\right.$ ha. $\left.h^{-1}\right)=$ Capacidade operacional de enleiramento.

$\mathrm{COE}_{2}\left(\mathrm{t} . \mathrm{h}^{-1}\right)=$ Capacidade operacional de enleiramento.

CONEE $_{1}\left(\right.$ L. ha $\left.^{-1}\right)=$ Consumo efetivo na operação de enleiramento.

CONEE $_{2}\left(\right.$ L. $\left.^{-1}\right)=$ Consumo efetivo na operação de enleiramento.

CONER $_{1}$ (L.repetição ${ }^{-1}$ ) = Consumo de combustível no recolhimento.

CONER $_{2}\left(\right.$ L. $\left.^{-1}\right)=$ Consumo de combustível no recolhimento.

$\operatorname{CONER}_{3}\left(\right.$ L.ha $\left.^{-1}\right)=$ Consumo de combustivel no recolhimento.

CONOE $_{1}\left(\right.$ L.ha $\left.^{-1}\right)=$ Consumo operacional na operação de enleiramento.

$\mathrm{CONOE}_{2}\left(\mathrm{~L} .^{-1}\right)$. $=$ Consumo operacional na operação de enleiramento.

CONOR (L.repetição $\left.{ }^{-1}\right)=$ Consumo operacional na operação de recolhimento.

$\mathrm{COR}_{1}\left(\mathrm{t} . \mathrm{h}^{-1}\right)=$ Capacidade operacional de recolhimento.

$\mathrm{COR}_{2}\left(\right.$ ha. $\left.\mathrm{h}^{-1}\right)=$ Capacidade operacional de recolhimento.

CPPU $\left(R \$ . t^{-1}\right)=$ Custo total do palhiço, a granel, posto na usina.

$\mathrm{CRP}\left(\mathrm{R} \$ \cdot \mathrm{t}^{-1}\right)=$ Custo da operação de recolhimento do palhiço.

$\mathrm{CTP}\left(\mathrm{R} \$ \cdot \mathrm{t}^{-1}\right)=$ Custo do transporte do palhiço, a granel. 
CTUT $\left(\right.$ EBP. $\left.t^{-1}\right)=$ Consumo total de energia, na forma de combustível, nas operações envolvidas no sistema (enleiramento, recolhimento, transporte e descarregamento).

DIST $\left(\right.$ m.repetição $\left.{ }^{-1}\right)=$ Distância percorrida.

$D L(m)=$ Distância entre leiras.

$E(\%)=$ Grau de umidade da madeira, com base em peso úmido.

ECC $\left(\mathrm{kcal} . \mathrm{Kg}^{-1}\right)=$ Energia consumida, na forma de óleo diesel.

$E C P_{1}\left(k c a l . K^{-1}\right)=$ Energia existente no palhiço.

$\mathrm{ECP}_{2}\left(\mathrm{EBP} . \mathrm{t}^{-1}\right)=$ Quantidade de energia, em equivalente barril de petróleo, existente no palhiço, posto na usina.

ELD $(\%)=$ Energia líquida disponivel existente no palhiço posto na usina.

$H(\%)=$ Teor de hidrogênio do material.

LARG $(m)=$ Largura média efetiva.

$L L(m)=$ Largura da leira.

$\operatorname{LML}(m)=$ Largura média da leira .

MB $(\mathrm{Kg})=$ Massa bruta do transbordo com matéria-prima e sem descontar a transferência de massa.

$M L(K g)=$ Massa líquida de matéria-prima colhida por repetição.

$\operatorname{MPAE}\left(\mathrm{Kg}^{\mathrm{m}} \mathrm{m}^{-2}\right)=$ Massa de palhiço antes do enleiramento.

MPDE $\left(\mathrm{Kg}^{-2} \mathrm{~m}^{-2}\right)=$ Massa de palhiço depois do enleiramento.

$\operatorname{MPE}\left(\mathrm{Kg}^{\mathrm{m}} \mathrm{m}^{-2}\right)=$ Massa de palhiço enleirado.

MS $\left(\mathrm{Kg} \cdot \mathrm{m}^{-2}\right)=$ Quantidade de massa seca de palhiço existente, antes do enleiramento, sobre o terreno.

MU $\left(\mathrm{Kg}^{-2} \mathrm{~m}^{-2}=\right.$ Quantidade de massa úmida de palhiço existente, antes do enleiramento, sobre o terreno.

$\mathrm{PCl}\left(\mathrm{Kcal}_{\mathrm{Kg}} \mathrm{Kg}^{-1}\right)=$ Poder calorífico inferior, base em peso úmido.

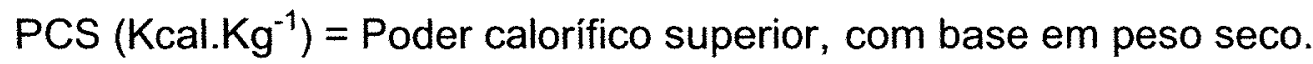

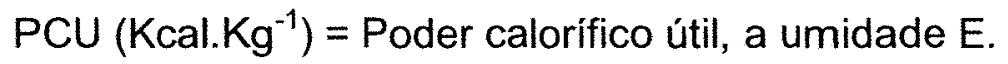

TEE (s.repetição $\left.o^{-1}\right)=$ Tempo efetivo de enleiramento.

TER $\left(\right.$ s.repetição ${ }^{-1}$ ) = Tempo efetivo de recolhimento.

TOE $\left(\right.$ s.repetição $\left.{ }^{-1}\right)=$ Tempo operacional de enleiramento. 
TOR (s.repetição $\left.{ }^{-1}\right)=$ Tempo operacional de recolhimento.

TT $(\mathrm{Kg})=$ Tara dos dois tambores metálicos de amostragem, contidos dentro do transbordo, junto com a matéria -prima colhida.

TPin $(\%)=$ Percentagem de terra do palhiço "in natrura", antes do enleiramento.

TPNT $(\%)=$ Percentagem de terra do palhiço, no transporte.

UPin $(\%)=$ Percentagem de umidade do palhiço "in natura", antes do enleiramento.

UPNT $(\%)=$ Percentagem de umidade do palhiço, no transporte.

VEE $\left(\mathrm{Km} \cdot \mathrm{h}^{-1}\right)=$ Velocidade efetiva de enleiramento.

VOE $\left(\mathrm{Km} \cdot \mathrm{h}^{-1}\right)=$ Velocidade operacional de enleiramento.

VER $\left(\mathrm{Km} \cdot \mathrm{h}^{-1}\right)=$ Velocidade efetiva de recolhimento.

VOR $\left(\mathrm{Km} \cdot \mathrm{h}^{-1}\right)=$ Velocidade operacional de recolhimento. 


\section{RESUMO}

\section{AVALIAÇÃO DE DOIS DIFERENTES ENLEIRADORES PARA O RECOLHIMENTO A GRANEL DE PALHIÇO EM CANA-DE-AÇÚCAR (Saccharum spp.)}

O presente trabalho avaliou e comparou dois diferentes equipamentos em ensaios padronizados de máquinas enleiradoras e recolhedoras de forragem operando sobre palhiço da cana-de-açúcar, colhida mecanicamente, sem queima prévia. O experimento foi desenvolvido em área pertencente ao Grupo COSAN, Usina Costa Pinto localizada entre as coordenadas geográficas de latitude $22^{\circ} 40^{\circ} 30^{\prime \prime} \mathrm{S}$ e longitude $47^{\circ} 36^{\circ} 38^{\prime \prime} \mathrm{W}$ com 580 metros de altitude, na cidade de Piracicaba, SP. Adotou-se o delineamento inteiramente casualizado para avaliar os dois diferentes tratamentos comparados neste estudo. Os ensaios abrangeram dois ancinhos enleiradores e uma recolhedora de forragem tracionada, sob duas condições de enleiramento do material, considerando-se as seguintes variáveis: Capacidades Efetiva e Operacional, consumo de combustivel, custo das operações de enleiramento e recolhimento, umidade do palhiço recolhido e a porcentagem de terra arrastada no material manipulado pelos ancinhos e pela recolhedora, massa de palhiço não manipulada (perdas) pelas operações, poder calorífico útil disponível e a eficiência energética do processo. Podese concluir que a utilização dos diferentes enleiradores não influenciou, de maneira significativa, nas características do palhiço recolhido, nem no desempenho operacional da recolhedora. Tanto a metodologia aqui adotada como o processo de recolhimento a granel podem ser considerados como uma opção viável no gerenciamento do palhiço de cana-de-açúcar deixado no campo após a colheita mecanizada, visando seu recolhimento para utilização na geração de energia elétrica.

PALAVRAS-CHAVE: cana-de-açúcar, palhiço, recolhimento, cogeração. 


\section{ABSTRACT}

\section{EVALAUATED OF TWO DIFFERENT ROWERS FOR SUGARCANE (Saccharum spp.) TRASH BIN COLLECTING SYSTEM}

This work aims to evaluated and compare two different equipments in standardized field tests used for rowing and for bin collecting system of sugarcane crop residue of mechanical harvest, on green cane. The experiment was developed in an area own by COSAN Group, on Costa Pinto sugar mill, located between latitude $22^{\circ} 40^{\circ}$ $30^{\prime \prime} \mathrm{S}$ and longitude $47^{\circ} 36^{\prime} 38^{\prime \prime} \mathrm{W}$ with 580 meters above sea level, at Piracicaba, SP. An entirely random experimental delineation was adopted to evaluate two different treatments adopted in this study. Tests comprehend two rower machines and different collecting systems of sugarcane crop residue under two different rower conditions, considering this variables: Effective and operational capacities, fuel consumption, cost of operations, percentage of moisture and dirt (soil) from sugarcane crop residue, loses within operations, heat power, available energy of the material per hectare and process efficiency. It could be concluded that the use of different rowers did not affected in a significant manner the sugarcane crop residue characteristic, as well as the collecting system operational performance. The methodology adopted and the bin collecting system can be considered as viable options to manage sugarcane crop residue left on fields after harvesting operations, in order to look for its own recollecting aiming electric energy generation.

KEYWORDS: sugarcane, sugarcane trash, collecting, cogeneration. 


\section{INTRODUÇÃO}

A cana-de-açúcar gera, assim como o petróleo, um grande número de produtos com importante diferencial: constitui uma das mais importantes fontes de biomassa potencialmente aproveitáveis para a cogeração de energia elétrica, e que é um recurso renovável e biodegradável.

No entanto, é preciso lembrar que, em principio, se cultiva cana-de-açúcar para produzir açúcar e álcool e, secundariamente, para gerar energia elétrica. De qualquer forma, é importante realçar o enorme potencial da cogeração de eletricidade a partir da cana-de-açúcar e, relatar que a quantidade de biomassa disponível para cogeração tem relação direta com a definição do tamanho dos mercados de açúcar e álcool; e que estes dependem da definição da matriz energética do país.

As crises de energia no país são reflexos de décadas de ausência de planejamento, pois o Brasil apresenta abundância de recursos em biomassa. Muito se tem falado na cogeração de energia a partir da biomassa de cana-de-açúcar como alternativa rápida e viável para amenizar a crise de energia do país. As vantagens da geração de energia elétrica com resíduos de cana-de-açúcar são óbvias e inúmeras. A principal delas é a de permitir a correção da oferta sazonal da hidroeletricidade, uma vez que a safra do setor sucroalcooleiro coincide com o período de seca, no qual há escassez de água para a geração de energia, principalmente no Centro-Sul.

As queimadas vem sendo utilizadas como prática de pré-colheita, porém essa prática passa a ser limitada pela legislação vigente. Assim, o que era queimado no campo ou considerado matéria estranha na colheita mecanizada, agora passa a ser visto como uma matéria prima aproveitável para cogeração de energia elétrica nas próprias usinas, recebendo o nome de palhiço. Este palhiço é formado por: folhas verdes, palhas, ponteiros e frações de colmos remanescentes após operações de colheita e terra arrastada, segundo Ripoli \& Ripoli (2004). A principal questão implica no processo da remoção desse material do campo, para posteriormente disponibilizá-lo na própria usina.

Dentro desse contexto, o recolhimento a granel do palhiço é uma das inúmeras opções a serem pesquisadas. 
O presente estudo avaliou e comparou duas máquinas enleiradoras e uma recolhedora de forragem operando sobre palhiço da cana-de-açúcar, colhida mecanicamente.

A hipótese de trabalho propõe que, o tipo de ancinho enleirador utilizado não reflita, significativamente, na quantidade de terra, na massa específica do material recolhido e na umidade do palhiço manipulado. 


\section{DESENVOLVIMENTO}

\subsection{Revisão Bibliográfica}

\subsubsection{A cana-de-açúcar, subprodutos, produção.}

O surgimento da cana-de-açúcar gera controvérsias como sendo a Polinésia ou Papua Nova Guiné o berço da gramínea. Entre a maioria dos historiadores, porém, aceita-se a hipótese de surgimento da cana entre 10 e 12 mil anos, e data em 3.000 a.C. o caminho percorrido pela cana da Península Malaia e Indochina à Baía de Bengala, porém, todos eles concordam com a origem asiática da cana. Ela foi introduzida na China por volta de 800 a.C. e o açúcar cru já era produzido em 400 a.C. Entretanto, só a partir de 700 d.C. começou a ser comercializado. Há relatos de sua expansão ocidental, atingindo Índia e Pérsia, que datam de 510 a.C., pela expedição militar persa do imperador Dario à Índia. A cana e o seu doce caldo, foram mantidos em segredo, já que o produto da planta era raro e luxuoso, principalmente para os povos distantes do comércio entre os asiáticos. (UNICA, 2003).

O ocidente europeu só ficou conhecendo a cana-de-açúcar no século XI quando os cruzados retornaram dos países árabes com diversas especiarias, inclusive o "mel pagão". Depois das descobertas das Grandes Navegações, a cana foi plantada no Brasil e adaptou-se ao clima e ao solo iniciando-se assim sua história no Brasil. A canade-açúcar é matéria-prima de grande flexibilidade. Com ela é possível produzir açúcar e álcool de vários tipos, fabricar bebidas, gerar eletricidade e demais produtos. Da canade-açúcar se aproveita absolutamente tudo: bagaço, mél, torta e resíduos de colheita e é uma das maiores fontes de biomassa disponivel. Como exemplo, pode-se citar a produção de açúcar e seus inúmeros produtos: o refinado granulado, refinado amorfo, glaçúcar, xarope invertido, açúcar líquido e açúcar orgânico. O Brasil está em $1^{\circ}$ lugar no ranking mundial como o maior produtor e exportador de açúcar. A produção de álcool em grande escala, sempre esteve ligada à produção de veículos movidos a álcool hidratado ou relacionado a sua adição à gasolina (entre 22 e $25 \%$ de álcool anidro). Dessa forma sua produção sempre se expandiu em épocas de crise de petróleo e, mediante o programa do Próalcool. Todavia, nunca deslanchou devido à incompetência logistica do governo e por interesses dos produtores de petróleo. No 
entanto, o Brasil é o detentor da maior tecnologia nesta área, sendo ainda o maior produtor e exportador mundial. (UNICA, 2003).

Tabela 1- Produção de açúcar (sacas de $50 \mathrm{Kg}$ ) de 1999 até 2002 no Brasil, Centro-Sul e São Paulo

\begin{tabular}{cccc}
\hline \multicolumn{4}{c}{ PRODUÇÃO DE AÇÚCAR (sacas de $50 \mathrm{Kg}$ ) } \\
\hline SAFRA & SÃO PAULO & CENTRO-SUL & BRASIL \\
\hline $99 / 00$ & 261.823 .580 & 337.996 .760 & 387.743 .420 \\
$00 / 01$ & 193.427 .760 & 252.636 .960 & 324.892 .240 \\
$01 / 02$ & 246.569 .540 & 319.007 .720 & $383.924 .700^{*}$ \\
\hline
\end{tabular}

Fonte: UNICA, 2003. * Dados do Norte-Nordeste até 01/06/2002.

Tabela 2- Produção de álcool total $\left(\mathrm{em} \mathrm{m}^{3}\right)$ para o Brasil, Centro-Sul e São Paulo PRODUÇÃO DE ÁLCOOL TOTAL $\left(\mathrm{em} \mathrm{m}^{3}\right)$

\begin{tabular}{cccc}
\hline SAFRA & SÃO PAULO & CENTRO-SUL & BRASIL \\
\hline $99 / 00$ & 8.486 .735 & 11.634 .234 & 13.002 .326 \\
$00 / 01$ & 6.439 .113 & 9.064 .364 & 10.589 .035 \\
$01 / 02$ & 7.118 .891 & 10.160 .652 & $11.515 .300^{*}$ \\
\hline
\end{tabular}

Fonte: UNICA, 2003. ${ }^{*}$ Dados do Norte-Nordeste até 01/06/2002.

Ainda, segundo UNICA (2003), além do açúcar e do álcool, com 3Kg de açúcar e $17,1 \mathrm{Kg}$ de bagaço pode-se obter, por exemplo, $1 \mathrm{Kg}$ de plástico biodegradável derivado da cana, utilizando-se como solventes outros subprodutos da usina. Do bagaço, obtémse: bagaço hidrolisado para alimentação animal, diversos tipos de papéis, fármacos e produtos como o furfurol, de alta reatividade, para a síntese de compostos orgânicos, com grande número de aplicações na indústria química e farmacêutica. Do melaço, além do álcool usado como combustível, bebida, e na indústria química, farmacêutica e de cosméticos, extraem-se levedura, mel, ácido cítrico, ácido lático, glutamato monossódico e desenvolve-se a chamada alcoolquímica, ou seja, as várias alternativas de transformação oferecidas pelo álcool etilico ou etanol. Do etanol podem ser fabricados polietileno, estireno, cetona, acetaldeído, poliestireno, ácido acético, éter, acetona e toda a gama de produtos que se extraem do petróleo. Seu variado uso inclui a fabricação de fibras sintéticas, pinturas, vernizes, vasilhames, tubos, solventes, 
plastificantes, etc. Dos resíduos, utilizam-se a vinhaça e o vinhoto como fertilizantes. Há ainda outros derivados: dextrana, xantan, sorbitol, glicerol, cera refinada de torta, antifúngicos, etc.

Do palhiço (composto por folhas verdes, ponteira da cana, frações de colmo e principalmente palha seca) podemos gerar energia através de sua queima nas usinas, de acordo com Ripoli ( 2001).

\subsubsection{A Queima de Canaviais}

Citado em Ripoli 2001,o Jornal A "Folha da Manhã" de São Paulo, em sua edição de 28 de abril de 1951, publicou a seguinte informação:

"O velho hábito das queimadas ainda persiste no espírito de muitos lavradores. Já é tempo porém de acabar com essa prática primitiva, empírica e prejudicial, para substituíla por processos racionais e equilibrados de trabalho. No que diz respeito à cana-de-açúcar, são inúmeros os prejuízos causados pela queima da palha, após o término da colheita".

A Secretaria do Meio Ambiente do Estado de São Paulo (SMA, 2003) em seu esforço de busca por um ambiente saudável e equilibrado, vem se empenhando para eliminar a prática da queima da palha da cana-de-açúcar, cujos reflexos na maioria dos casos são danosos para o bem-estar e a saúde da população nos grandes pólos sucroalcooleiros. Com esse objetivo o Prof. José Goldemberg secretário de Meio Ambiente do Estado de São Paulo, propôs ao governador Geraldo Alckmin a edição do Decreto $n^{\circ} 47.700$, de 11 de março de 2003, que regulamenta a Lei $n^{\circ} 11.241$, de 19 de setembro de 2002. A finalidade da lei e de seu regulamento é a eliminação total da prática da queima em canaviais de todo o Estado.

De acordo com o mesmo órgão publico, a inviabilidade de se implementar tal medida, de forma abrupta, levou a SMA a estabelecer os seguintes prazos, considerando os ciclos qüinqüenais, nos quais os canaviais são renovados:

Áreas mecanizáveis (áreas maiores que 150ha e com declividade menor ou igual a $12 \%$ ): $20 \%$ de redução imediata da área cortada; $30 \%$ a partir de 2006; $50 \%$ a partir de 2011; $80 \%$ a partir de 2016; $100 \%$ em 2021.

Áreas não-mecanizáveis (áreas menores que 150ha ou com declividade maior que $12 \%$ e aquelas com limitações ou obstáculos que impeçam a mecanização): $10 \%$ 
de redução a partir de2011; $20 \%$ a partir de $2016 ; 30 \%$ a partir de $2021 ; 50 \%$ a partir de 2026; $100 \%$ em 2031.

Como proibição expressa e imediata, encontram-se áreas próximas a aeroportos, rodovias, linhas de transmissão de eletricidade. O responsável pela queima deve cadastrar-se pelo requerimento de queima controlada, realizar a queima no período noturno, respeitando as condições de vento, evitar períodos de temperatura mais elevada, dar ciência formal da intenção de realizar a queimada, sinalizar adequadamente as estradas municipais e vicinais, manter equipe de vigilância e acompanhar todo o processo e não queimar área contínua superior a 500 ha.

Porém, a prática da queima de pré-colheita é consagrada por favorecer o aumento do desempenho operacional de colhedoras e de trabalhadores braçais, além de reduzir a matéria estranha vegetal que acompanha a matéria prima, dentre outras discutiveis justificativas (Furlani Neto et. al., 1997).

Conforme Ripoli \& Paranhos (1987), a queima dos canaviais, apesar dos prejuizos ao ambiente, apresenta reflexos positivos e imediatos que justificam a prática, facilitando, sobremaneira, a operação de colheita e reduzindo entre 60 e $90 \%$ a quantidade de matéria estranha vegetal que acompanha a matéria prima.

A queima prévia dos canaviais é consagrada em função dos reflexos econômicos imediatos que oferece, segundo Ripoli (1988). No entanto, existem inconvenientes na prática da queima de canaviais, como a dificuldade de implantação de controle biológico, perda de sacarose, aumento de impurezas minerais, riscos de incêndios por descontrole e desperdício de 10t/ha (em média) de biomassa, que poderiam ser aproveitadas para incorporação ao solo ou como fonte energética.

Delgado (1985) cita as vantagens das queimadas: Cria facilidades no preparo do solo e de cultivo; oferece facilidades nas operações de corte tanto manual como mecanizado; colabora com a eliminação de pragas das culturas; torna a colheita mais fácil e barata. Nesse mesmo contexto, cita também as desvantagens das queimadas: $A$ palha pode ser incorporada ao solo aumentando o seu teor de matéria orgânica; leva a morte dos inimigos naturais da broca da cana; ocasiona dificuldades na conservação e purificação dos caldos; provoca o aumento do brix e da porcentagem de fibra na canade-açúcar devido ao ressecamento dos colmos; viabiliza o aumento da infestação de 
microorganismos nos colmos, como resultado da exsudação, deteriorando-os; causa maiores prejuizos no caso de atraso do corte; provoca complicações para o tratamento da água de lavagem, pelo aumento do volume necessário e pela demanda de oxigênio devido ao exsudado e pela solubilização de ceras; a queima tem causado perdas da ordem de $30 \%$ da matéria bruta, as quais poderiam ser utilizadas para a cogeração de energia.

Bassinello et al. (s.d.) aborda como vantagens de canaviais colhidos sem a queima prévia: o controle de plantas daninhas sem a utilização ou com uma menor dosagem de herbicidas; aumento de matéria orgânica no solo após vários anos sem queimar; melhor aproveitamento energético da cana na indústria; a prática de colheita crua beneficia as micro e mini destilarias, que devido a sua baixa capacidade de processamento, tem dificuldade na queima de talhões inteiros; redução da poluição atmosférica; melhor qualidade da matéria prima entregue na indústria; redução na população de nematóides nocivos pelo aumento dos nematóides predadores (benéficos) e outros microorganismos resultantes do acréscimo de matéria orgânica; diminuição do efeito erosivo gerado pelo impacto das chuvas, em função da camada protetora; manutenção da umidade do solo. Como desvantagens desse processo a dificuldade de mão-de-obra para a adoção da técnica e a resistência do próprio cortador em executá-la; desempenho de corte menor, tanto manual como mecanizado, implicando em maiores custos de produção; aumento de matéria estranha na matériaprima; tendência de corte basal mais alto, prejudicando a brotação da soqueira; dificuldade de brotação de soqueira devido a menor temperatura do solo e ao sombreamento; maior infestação de pragas; impossibilidade de utilização de implementos tradicionais nos tratos culturais de adubação e cultivo (subsolagem); necessidade de maior quantidade de nitrogênio na adubação de soqueira, com a finalidade de suprir a parte imobilizada na decomposição da palha e aplicação no plantio de todo o fósforo, exigido durante o ciclo da cultura; perigo de fogo acidental; escolha de variedades apropriadas (sem joçal, fácil despalha e com menor problemas de doenças e broca); aumento da necessidade de transporte; aumento no teor de fibra e conseqüente redução na extração de caldo pelas moendas; as colhedoras de cana foram basicamente desenvolvidas para o corte de cana queimada (com raras 
exceções); diminuição na velocidade das colhedoras com aumento do consumo operacional e do custo final; aumento da presença de animais peçonhentos na hora do corte, ocasionando acidentes (principalmente na colheita manual); maior incidência de broca (D. saccharalis) e de cigarrinha da raiz (M. fimbriolata).

Para Urquiaga et al. (2001), o palhiço serve como uma reserva de nutrientes que são liberados lentamente com a sua decomposição, em contraste com os nutrientes contidos nas cinzas que são rapidamente lixiviados numa época imediatamente após a colheita.

Payne (1986), discutiu os efeitos da queima do ponto de vista das perdas de açúcar e energia, e concluiu que esta pode implicar em redução de até $50 \%$ da biomassa da planta, bem como, reduções não desprezíveis no teor de sacarose. A composição da biomassa, associada às pontas e folhas da cana é apresentada na Tabela 3.

Tabela 3- Composição do colmo e das folhas da cana-de-açúcar

\begin{tabular}{lcc}
\hline COMPONENTES & COLMOS & PONTAS E FOLHAS \\
\hline Matéria seca & 29,00 & 26,00 \\
Açúcares totais & 15,43 & 2,18 \\
Sacarose & 14,10 & - \\
Lignina e celulose & 12,21 & 19,80 \\
Cinzas & 0,54 & 2,31 \\
Outros componentes & 0,82 & 2,43 \\
Água & 71,00 & 74,00 \\
\hline
\end{tabular}

Fonte: Potencial energético da cana-de-açúcar (Payne, 1986).

Ripoli et al. (1998) citaram os inconvenientes da prática da queima de canaviais, como a dificuldade de implantação de controle biológico, perda de sacarose, aumento de matéria estranha mineral, risco de incêndios por descontrole e o desperdício de 10t/ha, em média, de biomassa que poderiam ser aproveitadas para a incorporação ao solo ou como fonte energética.

Sobre a incidência de pontas, folhas e palha no conjunto da massa de cana verde, Ripoli et al. (1990a) apresentou valores na faixa de 20 a $30 \%$ em função da variedade de cana-de-açúcar considerada. Na avaliação dos autores, por hectare de 
área colhida, existe mais energia nos resíduos do que no próprio bagaço, enquanto que a quantidade de pontas e folhas depende da variedade, das práticas agrícolas adotadas e da idade da cana-de-açúcar.

Além desses problemas anteriormente apontados, soma-se a pressão de caráter político-social, que o setor vem sofrendo por parte da sociedade. As denúncias de condições indignas e insalubres de trabalho como a publicação do Jornal de Piracicaba (2003), onde a Pastoral do Imigrante, organismo da CNBB (Conferencia Nacional dos Bispos do Brasil) e a Comissão de Direitos Humanos e Cidadania da Câmara de Vereadores de Piracicaba relata a exploração (semi-escravização) de pelo menos doze mil e seiscentos trabalhadores temporários migrantes.

A exigência de que a colheita seja realizada sem que haja agressão ao ambiente tem crescido por parte dos ambientalistas e passa a encontrar respaldo no setor político, à medida que a demanda por investimento de capital de outros setores tecnológicos exige um melhor controle da qualidade do ar, pois, a queimada, por causa da fuligem, afugenta investimentos de indústrias que geram tecnologia.

Segundo Ripoli \& Villanova (1992) por vários anos a indústria canavieira vem sofrendo um processo de combate sistemático, passional e sem nenhum embasamento científico, se fazendo necessária à desmistificação da imagem que a agroindústria canavieira é altamente poluidora.

A queimada de canaviais deve ser combatida sim, mas não especificamente pelo aspecto de agressão ao ambiente mas, basicamente, por tratar-se de um desperdício de energia significativo, num país carente desta. Desperdício esse caracterizado pela queima do palhiço de cana-de-açúcar que, segundo trabalhos em desenvolvimento pelo departamento de Engenharia Rural da ESALQ, representa, em média, 32,5\% de toda a biomassa produzida por um canavial, conforme Ripoli \& Villanova (1992). E mais, ainda que se façam necessários mais estudos a respeito, o setor sucroalcooleiro está sendo atropelado pela realidade da colheita de cana sem queima prévia. Sob essas condições, tudo está por fazer, além do que a experiência da mecanização em cana queimada, pouco contribui para solucionar os problemas a serem enfrentados na colheita de cana crua. 


\subsubsection{Considerações sobre o poder calorífico}

O Poder Calorífico Superior (PCS) de um combustível é determinado levando-se em conta o calor liberado pela condensação da água do combustivel avaliado, enquanto que, o Poder Calorífico Inferior $(\mathrm{PCl})$ de um combustível determina-se como sendo o calor liberado pelo combustível sem considerar o calor liberado pela vaporização da água segundo Brito \& Barrichello (1982).

Doat (1977), apresenta além do PCS e PCI, o Poder Calorífico Útil (PCU) com base em peso úmido, deduzindo-se a energia consumida na evaporação da água de formação. Para se chegar ao PCS, PCl e PCU, aplicam-se as equações 1 e 2.

$\mathrm{PCl}=\mathrm{PCS}-(600.9 . \mathrm{H} / 100)$

Sendo:

$\mathrm{PCl}\left(\mathrm{Kcal}_{\mathrm{Kg}} \mathrm{K}^{-1}\right)=$ Poder calorífico Inferior, com base em peso úmido.

PCS $\left(\mathrm{Kcal}_{\mathrm{Kgg}} \mathrm{K}^{-1}\right)=$ Poder calorífico Superior, com base em peso seco.

$H \%=$ Teor de hidrogênio do material.

$600($ Kcal $)=$ Valor médio de energia absorvida por $\mathrm{Kg}$ de água para se atingir a temperatura de evaporação.

9 = Múltiplo do peso de hidrogênio contido no combustivel, que fornece o peso da água durante a combustão.

$\mathrm{PCU}=\mathrm{PCl} .((100-\mathrm{E}) / 100)-6 \cdot \mathrm{H}$

Sendo:

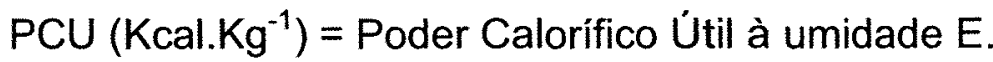

$\mathrm{E} \%=$ Grau de umidade da madeira, com base em peso úmido.

6 = Fator de conversão referente à energia, para a evaporação da água de formação.

De acordo com Sleiman (1998), o bagaço de cana-de-açúcar, na saída da esteira apresenta, em média, $50 \%$ de umidade, PCS de $2264 \mathrm{Kcal} . \mathrm{Kg}^{-1}$ e PCl de $1800 \mathrm{Kcal} . \mathrm{Kg}^{-}$

1. Já a granel e com umidade de $25 \%$ tem PCS de $3249 \mathrm{Kcal}^{\mathrm{Kg}}{ }^{-1}$ e PCl de 3013 Kcal. $\mathrm{Kg}^{-1}$.

Zulauf, et al (1985) realizaram análises preliminares sobre o potencial energético da palha dos canaviais brasileiros, caso eles não fossem queimados, como operação de pré-colheita. Os mesmos autores estimaram que na safra $84 / 85$, devido à prática de 
queima prévia, poderia estar se desperdiçando até $87.720 \mathrm{Mcal}^{-a n o^{-1}}$, o que equivale à importação de 342.000 barris diários de petróleo, durante 162 dias, o que por sua vez, permitiria abastecer o país durante 63 dias, com uma economia de divisas da ordem de US\$1464. $10^{9}$.

Estes autores apresentam os dados representados pela Tabela 4, com os poderes caloríficos superior ( $P C S)$ e inferior $(P C l)$, em valores médios para a palha da cana-de-açúcar (folhas secas), ignorando as folhas verdes e os ponteiros e, quanto à quantidade de palha (folhas secas) existente num canavial, este trabalho apenas cita dados de outros autores: IAA, $5 \%$ a $14 \%$; Cuba, $11,1 \%$ a $19 \%$; Usina Sta Lídia, 30 a $50 \%$.

Tabela 4- Análises preliminares sobre o potencial energético da palha em canaviais brasileiros

\begin{tabular}{cccccc}
\hline REGIÃO & VARIEDADE & UMIDADE (\%) & $\mathrm{H}(\%)$ & $\begin{array}{c}\mathrm{PCS} \\
\left(\mathrm{Kcal}^{\left.\mathrm{K} \mathrm{Kg}^{-1}\right)}\right)\end{array}$ & $\begin{array}{c}\mathrm{PCl} \\
\left(\mathrm{Kcal}^{\mathrm{K}} \mathrm{Kg}^{-1}\right)\end{array}$ \\
\hline Bauru & SP701143 & 21,3 & 5,0 & 4315 & 3073 \\
Piracicaba & NA5679 & 18,6 & 3,4 & 3979 & 2992 \\
Araraquara & NA5679 & 9,1 & 4,0 & 4181 & 3563 \\
Rib. Preto & SP701143 & 8,0 & 4,0 & 4096 & 3534 \\
Campinas & CP5122 & 11,3 & 4,0 & 4098 & 3389 \\
\hline
\end{tabular}

Fonte: Zulauf, et al. (1985).

O ex-ministro Camillo Penna, citado por Ripoli et al. (1991b), afirmou que o Brasil produzia 50 milhões de toneladas de bagaço de cana/ano e a mesma quantidade de pontas e palha e que o aproveitamento destes poderia gerar 4,8 mil megawatts, que corresponde a $8 \%$ de toda a energia elétrica gerada nesta época no país.

Os resultados obtidos por Furlani Neto et al. (1997), permitem visualizar que é marcante a quantidade de energia disponível no palhiço, pois transformando valores obtidos em estudos sem queima prévia e transformando-os em equivalente barris de petróleo (EBP) se obtém o valor de $0,76 \mathrm{EBP} / \mathrm{t}$, que está sendo desperdiçado nos canaviais de hoje.

Em estudos de campo, na usina Santa Lídia, no município de Ribeirão Preto, São Paulo, safra de 89/90, Ripoli et al. (1990a) determinaram em três variedades de 
cana-de-açúcar, colhidas manualmente e sem queima prévia, cujos resultados encontram-se na Tabela 5. O IP (índice de palhiço) é uma variável percentual criada por esses autores que correlaciona as massas de ponteiros, folhas verdes e palha com massas de colmos industrializáveis, por unidade de área do canavial.

Tabela 5- Resumo dos resultados obtidos por Ripoli et al. (1990a), de diversas variáveis do palhiço de cana-de-açúcar

\begin{tabular}{|c|c|c|c|c|}
\hline \multirow[t]{2}{*}{ Variáveis } & \multicolumn{3}{|c|}{ Variedades } & \multirow[t]{2}{*}{ Médias } \\
\hline & SP701284 & SP706163 & SP701143 & \\
\hline \multicolumn{5}{|l|}{$U \%$} \\
\hline Ponteiros & $74,5(1,58)$ & $76,68(2,89)$ & $79,46(2,89)$ & $76,88(3,30)$ \\
\hline Folhas verdes & $62,47(2,03)$ & $63,94(3,11)$ & $70,79(3,83)$ & $65,73(6,47)$ \\
\hline Palhas & $6,89(5,66)$ & $8,75(18,74)$ & $7,26(21,08)$ & $7,63(18,74)$ \\
\hline IP & $0,17(9,48)$ & $0,31(7,96)$ & $0,25(9,84)$ & $0,24(25,42)$ \\
\hline \multicolumn{5}{|r|}{$0,<+(<0,7<1$} \\
\hline Ponteiros & $6,20(0,23)$ & $6,27(1,48)$ & $6,23(1,60)$ & $6,23(0,67)$ \\
\hline Folhas verdes & $6,33(0,24)$ & $6,33(0,24)$ & $6,26(0,88)$ & $6,43(0,00)$ \\
\hline \multicolumn{4}{|l|}{ PCS } & $6,23(0,67)$ \\
\hline Ponteiros & $4481,9(3,24)$ & $4182,1(3,25)$ & $4222,7(3,57)$ & $4297,2(4,60)$ \\
\hline Folhas verdes & $4407,9(2,47)$ & $4470,9(3,78)$ & $4229,8(2,31)$ & $4392,8(3,21)$ \\
\hline $\begin{array}{l}\text { Palhas } \\
\mathrm{PCl}\end{array}$ & $4283,6(1,66)$ & $4295,7(4,84)$ & $4276,4(4,85)$ & $4285,2(3,53)$ \\
\hline Ponteiros & $4147,1(3,24)$ & $3843,6(3,25)$ & $3891,4(3,57)$ & $3960,7(4,60)$ \\
\hline Folhas verdes & $4407,9(2,47)$ & $4132,5(3,78)$ & $3952,8(2,31)$ & $3948,9(3,53)$ \\
\hline $\begin{array}{l}\text { Palhas } \\
\text { PCU }\end{array}$ & $3949,7(1,79)$ & $3958,9(5,25)$ & $3938,3(5,29)$ & $3938,9(3,53)$ \\
\hline Ponteiros & $1020,6(7,26)$ & $858,5(4,31)$ & $762,1(12,28)$ & $880,4(14,74)$ \\
\hline Folhas verdes & $1487,1(2,47)$ & $1453,3(7,74)$ & $1114,7(7,69)$ & $1351,7(14,22)$ \\
\hline $\begin{array}{l}\text { Palhas } \\
\text { CPP }\end{array}$ & $3640,4(1,41)$ & $3573,5(4,42)$ & $3615,7(7,08)$ & $3609,8(3,97)$ \\
\hline Ponteiros & $27,63(23,38)$ & $31,17(15,57)$ & $24,38(25,51)$ & $27,50(22,11)$ \\
\hline Folhas verdes & $33,91(22,38)$ & $37,12(13,33)$ & $40,36(23,12)$ & $36,86(20,48)$ \\
\hline Palhas & $38,46(24,13)$ & $31,71(6,72)$ & $35,26(13,92)$ & $35,14(18,41)$ \\
\hline
\end{tabular}

Ripoli (1991a) estimou, para as variedades SP711406 e NA5679, no estado de São Paulo, o valor energético do palhiço em equivalente barril de petróleo (EBP). Os valores médios obtidos foram 1,28 EBP. $\mathrm{t}^{-1}$ de palhiço e 30,90 EBP.ha ${ }^{-1}$. 


\subsubsection{A biomassa}

No mundo contemporâneo, a energia proveniente dos combustíveis fósseis, tais como: o petróleo, carvão mineral e gás natural é a mais consumida (Figura 1). Dessa forma, o vertiginoso progresso aumentou drasticamente o consumo dos combustiveis fósseis, a ponto de indicarem o seu esgotamento de reservas em poucas décadas, se mantidas as taxas atuais de crescimento industrial, conforme Neiva (1987).

Segundo Sleiman (1998), resta ao mundo desenvolver fontes alternativas de energia, que sejam renováveis, para que o petróleo e os demais combustíveis fósseis, possam ser destinados a usos mais nobres. O mesmo autor cita que nesse contexto, o Brasil tem posição potencialmente privilegiada, já que dispõe de recursos naturais abundantes e pouco utilizados, principalmente no que diz respeito à biomassa.

\section{OFERTA DE ENERGIA POR FONTE - 1998}

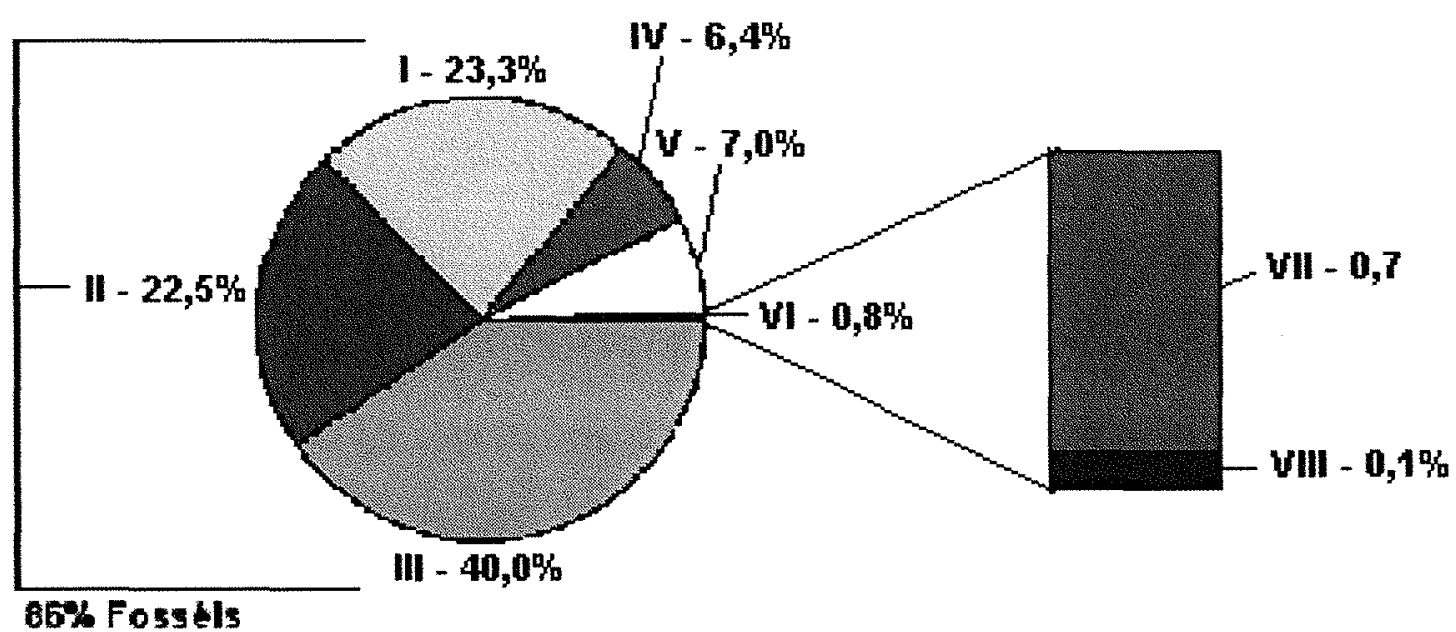

Fonte: ANEEL, 2001. Sendo: I= Carvão; $\|=$ Gás natural; $\| I=$ Petróleo; IV= Nuclear; V= Hidroeletricidade; VI= Outros; VII= Biomassa e outros; VIII= Álcool Brasil.

Figura 1- Balanço energético mundial

Etsu \& Harwell (2001) cita que a biomassa é a quarta fonte de energia do planeta, representando o principal combustível utilizado, aproximadamente, por $75 \%$ da população mundial.

De acordo com Carioca \& Aurora (1984), a utilização da biomassa para fins energéticos pode ser classificada como: recursos florestais, culturas energéticas (sacarídeas, amiláceas e oleaginosas), fitomassa aquática, residuos agropastoris, residuos orgânicos industriais, resíduos Urbanos sólidos e líquidos. 
Sendo essa biomassa normalmente constituída de resíduos e ou subprodutos originados na agroindústria, florestal e de uso doméstico, o valor comercial destes, geralmente, é muito baixo e quando são displicentemente dispostos no ambiente, por meio do despejo ou queima, os restos orgânicos são causadores de poluição ambiental e ocasionam risco à saúde. No entanto Rossi (1999), considera que caso sejam manejados e utilizados adequadamente, poderiam ser aproveitados de forma economicamente viável.

Segundo Coelho (2001), pode-se explorar a energia contida na biomassa de diferentes formas, sendo mais comum a utilização do calor proveniente da combustão, seja diretamente, ou produzindo vapor para gerar eletricidade.

\subsubsection{Eficiência fotossintética}

O sol é a principal fonte de energia na natureza e, segundo o site do CPTEC INPE (Centro de Previsão do Tempo e Estudos Climáticos - Instituto Nacional de Pesquisas Espaciais) a radiação que chega a nossa órbita é de 1360 watts $/ \mathrm{m}^{2}$. Aproximadamente, 51 \% dessa energia chega à superfície da terra e estima-se que a contribuição da energia solar no ciclo fotossintético seja de apenas $0,02 \%$ da radiação solar total (CPTEC-INPE, 2003).

Segundo Carioca \& Aurora (1984), o processo fotossintético é, na verdade, a mais prática utilização de energia solar, tanto pela sua natureza, como pela sua distribuição na Terra. Em relação aos processos físicos de utilização de energia solar, os componentes fotossintéticos apresentam a vantagem de armazenar essa energia sob a forma de ligações químicas estáveis, a qual pode ser liberada com o emprego do processo de conversão. A energia solar convertida em energia química está presente nos vegetais sob a forma de carboidratos.

\subsubsection{A matriz energética brasileira}

Apesar do Brasil ser um pais de grande potencial em biomassa, recursos hídricos e outras fontes de energia (Figura 2), hoje vem sofrendo com a ameaça de uma crise energética, sendo a principal causa dessa crise a falta de investimentos no setor que acompanhassem o crescimento do país, além de políticas errôneas de 
investimentos nesta área. O parque gerador brasileiro é composto, predominantemente, por usinas hidrelétricas com, aproximadamente, $86 \%$ do total, seguido por termoelétricas com $12 \%$ e nucleares com $1 \%$. Do ponto de vista social, a questão é mais grave, pois há necessidade de grandes reservatórios para diminuir o custo do $\mathrm{Kw}$ instalado, inundando grandes áreas agricultáveis, criando problemas com as famílias atingidas pelas barragens, além de estar agredindo e transformando o ecossistema. Do ponto de vista institucional e financeiro, o setor elétrico vive uma crise de relativa profundidade $e$, dificilmente terá condições de viabilizar-se com recursos próprios e, dentro da atual estrutura organizacional, a expansão do sistema de abastecimento torna-se inviável em um ritmo mais acelerado. Agravando-se estes fatores, a maior parte deste potencial hídrico disponível, encontra-se distante dos principais centros consumidores (Tabela 6), o que praticamente dobra o custo do $\mathrm{Kw}$, considerando-se a transmissão e distribuição desta energia, de acordo com Faccenda (1996).

\section{OFERTA DE ENERGIA POR FONTE , ANO - 2000}

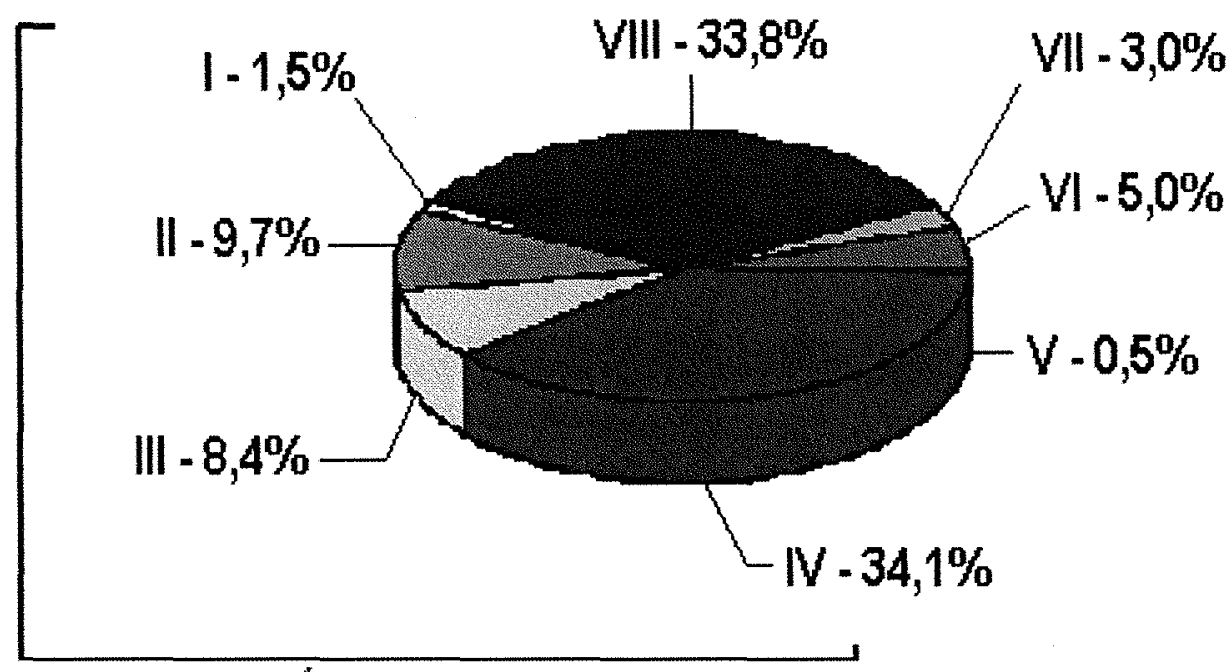

\section{SEX RENOVAVES}

Fonte: ANEEL (2001). Sendo: I= Outras fontes primárias; $\|=$ Derivados de cana-de-açúcar; III= Lenha e carvão vegetal; IV= Hidráulica e eletricidade; $V=$ Urânio (U308) e derivados; VI= Carvão mineral e derivados; VII= Gás natural; VIII= Petróleo e derivados.

Figura 2- Balanço energético nacional 
Um estudo mais atual da instituição francesa Banque Paribas, mostra que o Brasil é o quarto maior mercado de energia elétrica do planeta e, praticamente, triplicou o seu consumo energético, entre 1970 e 1999, com um crescimento anual de 4,36\%, sendo mais de $95 \%$ da energia elétrica produzida de origem hidráulica.

Tabela 6- Situação atual do setor de energia elétrica nacional

\begin{tabular}{|c|c|c|c|c|c|c|c|}
\hline \multicolumn{8}{|c|}{ CAPACIDADE DE GERAÇÃO INSTALADA NO PAIS - Mw - 2001} \\
\hline & \multicolumn{2}{|c|}{ Hidroelétricas } & \multicolumn{2}{|c|}{ Térmicas } & \multirow[t]{2}{*}{ Importada } & \multicolumn{2}{|l|}{ Total } \\
\hline & Capacidade & Efetiva & Capacidade & Efetiva & & Capacidade & Efetiva \\
\hline SE/CO & $\begin{array}{c}31.547 \\
80 \%\end{array}$ & 25.427 & $\begin{array}{l}3.807 \\
10 \%\end{array}$ & 3.046 & $\begin{array}{l}4.000 \\
10 \%\end{array}$ & 39.354 & 32.472 \\
\hline $\mathrm{S}$ & $\begin{array}{c}14.337 \\
82 \%\end{array}$ & 11.556 & $\begin{array}{l}2.231 \\
13 \%\end{array}$ & 1.785 & $\begin{array}{c}1.000 \\
6 \%\end{array}$ & 17.568 & 14.340 \\
\hline $\mathrm{N}$ & $\begin{array}{l}4.736 \\
100 \%\end{array}$ & 3.817 & & & & 4.736 & 3.817 \\
\hline NE & $\begin{array}{c}10.595 \\
96 \%\end{array}$ & 8.540 & $\begin{array}{l}455 \\
4 \%\end{array}$ & 364 & & 11.050 & 8.904 \\
\hline TOTAL & $\begin{array}{c}61.215 \\
84 \%\end{array}$ & 49.339 & $\begin{array}{c}6.493 \\
9 \%\end{array}$ & 5.195 & $\begin{array}{c}5.000 \\
7 \%\end{array}$ & 72.708 & 59.534 \\
\hline
\end{tabular}

Fonte: ANEEL, 2001.

Segundo Faccenda \& Souza (1997) o potencial de recursos hídricos destinados à geração de energia elétrica no estado de São Paulo está praticamente esgotado. $O$ Estado de São Paulo é responsável pelo consumo de, aproximadamente, um terço de toda a energia consumida no país, caracterizando-se como o grande importador de energia de outros estados. Por outro lado, é responsável igualmente por mais de $60 \%$ da biomassa proveniente da cana, sendo que este potencial pode ser explorado pela iniciativa privada para a cogeração de energia elétrica, sem demandar recursos públicos.

De acordo com Coelho e Zylbersztajn (1998), um dos motivos do desinterêsse por parte das usinas em investir na geração de excedentes é o preço pago pela concessionária, considerado não satisfatório pelas usinas, sendo então, mais interessante vender o excedente do bagaço, do que gerar eletricidade.

Castro (1996), revela que a CESP e CPFL pagavam às usinas tarifas que variavam de $\mathrm{R} \$ 0,011$ a $\mathrm{R} \$ 0,035$ por $\mathrm{Kw} / \mathrm{h}$ (conforme a duração do contrato entre a usina e a empresa de eletricidade) e repassavam esse excedente de energia aos consumidores da rede pública a $\mathrm{R} \$ 0,07$ por $\mathrm{Kw} / \mathrm{h}$. 
Frente a tais dificuldades observadas anteriormente para a produção de energia elétrica e a possibilidade da utilização do bagaço de cana para outros fins (como ração, por exemplo), um sistema bastante vantajoso seria a cogeração de eletricidade a partir da queima do palhiço da cana-de-açúcar pois, Ripoli \& Molina Jr. (1991b), estimaram que de um hectare de canavial pode-se obter em torno de $67.080 \mathrm{Mcal}$, em equivalente energético, assim distribuídos: 20,09 \% na atual produção de álcool, 40,03 \% no atual aproveitamento do bagaço, como combustível para fornalhas de caldeiras de usinas e destilarias e os restantes $39,88 \%$, estariam contidos no material remanescente na colheita (ponteiros, folhas verdes e palhas, principalmente) o qual, até o momento, não é aproveitado, pois é queimado como operação de pré-colheita, causando, inclusive, danos ao meio ambiente.

\subsubsection{A cogeração de energia}

Embasados pelo possível risco de desequilíbrio da oferta e demanda de energia elétrica do pais, agravados com o racionamento e a presença de "apagões", tendo ainda, além desses problemas, um futuro esperado e nada promissor de escassez de recursos não renováveis, os quais, foram muito explorados sem critérios, nem planejamento, a cogeração de energia a partir de fontes renováveis, como a biomassa, passou a ser a solução mais sensata para um futuro promissor.

Segundo Sleiman (1998), cogeração pode ser entendida como geração e uso seqüencial de energia elétrica ou mecânica e de energia térmica, partindo do calor fornecido por uma reação de combustão.

Poole (1993) aponta a cogeração como sendo a melhor opção energética para o Brasil, prevendo um futuro promissor e, para Souza (1999), a cogeração é a produção simultânea de energia térmica e elétrica a partir de uma mesma fonte de combustível.

O processo de cogeração corresponde à geração simultânea de energia térmica e mecânica, a partir de uma mesma fonte primária de energia. A energia mecânica pode ser utilizada na forma de trabalho (exemplo: o acionamento de moendas numa usina de açúcar e álcool) ou transformada em energia elétrica por meio de gerador de eletricidade. O combustível utilizado na cogeração pode ser petróleo, gás natural, carvão ou biomassa, segundo Coelho (2001). 
A partir da década de 70 , as usinas aproveitaram as atrativas linhas de financiamento e adquiriram equipamentos (como turbogeradores) e partiram para a geração de energia, buscando a auto-suficiência, segundo a CPFL (1988).

A situação do setor sucroalcooleiro, em termos de cogeração, alterou-se muito pouco segundo Coelho (2001), Walter (1993), entre outros. O setor é praticamente auto-suficiente em termos energéticos, mas, a geração de excedentes é ainda bastante reduzida.

Segundo Bartholomeu et al.(2001), as usinas por ele analisadas possuem um consumo específico de vapor no processo de cogeração, na faixa entre 450 a $560 \mathrm{Kg} / \mathrm{t}$ de cana. Verificou-se que há predomínio de caldeiras de baixa pressão. Todas as usinas utilizam caldeiras de 21 bar e algumas de 42 bar. Somente $7 \%$ também utilizam caldeira com pressão maior, como de 63 bar. Com relação à capacidade instalada na usina, o autor cita que esta variou entre $8,2 \mathrm{Mw}$ e $45,0 \mathrm{Mw}$, enquanto o consumo de energia esteve entre 6,4 Mw e 17,0 Mw.

Para Eletrobrás 1999, a potencia instalada $(\mathrm{Mw})$ de cogeração no setor sucroalcooleiro concentra-se na região sudeste (Figura 3). Percebe-se, portanto, que há um excesso de capacidade instalada, que poderia ser aproveitada para a cogeração. De fato, $71,4 \%$ das usinas pesquisadas possuem excedente de capacidade instalada, que varia desde 1,0 Mw até $30,0 \mathrm{Mw}$. Isto não significa, entretanto, que a usina gera toda esta quantidade de energia, mas somente o necessário para suas atividades. Algumas delas já possuem contrato de fornecimento de energia com concessionárias, e outras estão com projetos de estudo de viabilidade. Por outro lado, $14,3 \%$ das usinas consomem exatamente o que são capazes de gerar e outros $14,3 \%$ possuem um consumo de energia maior do que a capacidade instalada.

Cada tonelada de cana-de-açúcar moída produz, aproximadamente, de 250 a 260 quilos de bagaço, considerando um teor de fibra médio de $13 \%$ com cerca de $50 \%$ de umidade. Por sua vez, cada quilo de fibra seca produz cinco quilos de vapor quando queimado (Secretaria de Energia do Estado de São Paulo, 1997).

De acordo com Eid et al. (1998), para a produção de $1 \mathrm{Mw} \cdot \mathrm{h}^{-1}$ de energia, por meio do sistema de cogeração, é necessária a queima de 6,5 toneladas de bagaço. 
Potência instalada (MM) de cogeraçẵo do setor sucroalcooleiro (1999)

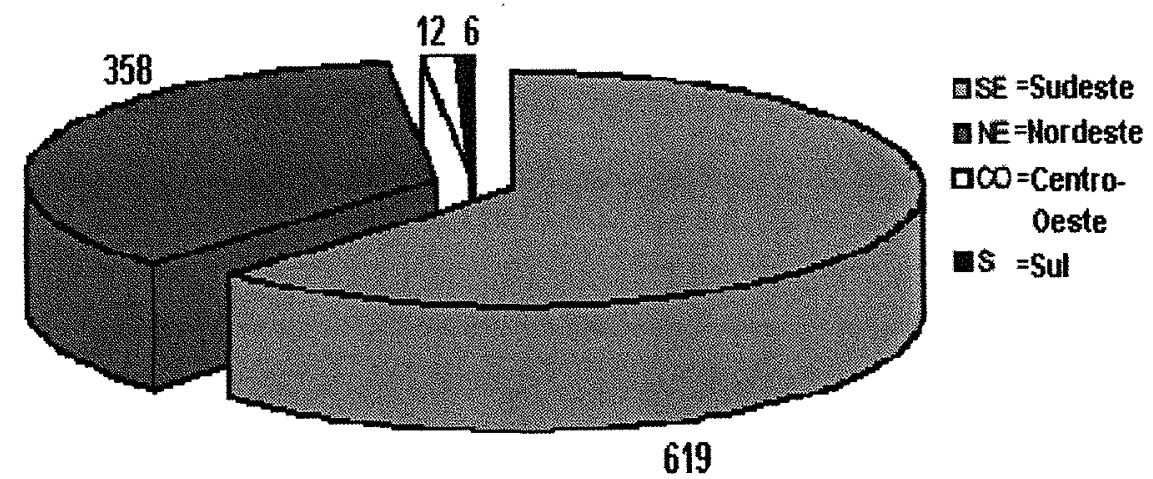

Fonte: Eletrobrás, 1999.

Figura 3- Potência instalada ( $\mathrm{Mw}$ ) de cogeração do setor sucroalcooleiro (1999)

No ano de 1997, o potencial gerado pelos cogeradores foi estimado pela CPFL em 33,7 Mw, SLEIMAN (1998).

A evolução da produção de energia cogerada por meio do bagaço de cana, pode ser observada na Tabela 7. Percebe-se que a geração de energia, pelo setor sucroalcooleiro, tem importância na matriz energética brasileira, ocupando o segundo ou terceiro lugares em termos de volume de produção (Gwh) entre os anos de 1988 e 1998. Além disso, pode-se observar que a cogeração vem apresentando significativo crescimento (11,9 \% no período analisado), segundo o Ministério de Minas e Energia (1999).

Tabela 7- Produção de eletricidade por fonte de geração em Gwh de 1988 - 1998

\begin{tabular}{cccccccccc}
\hline Ano & Bagaço & Carvão & $\begin{array}{c}\text { Gás } \\
\text { natural }\end{array}$ & Hidro & Lenha & Lixívia & $\begin{array}{c}\text { Óleo } \\
\text { combustivel }\end{array}$ & Diesel & $\begin{array}{c}\text { Outras } \\
\text { fontes }^{2}\end{array}$ \\
\hline 1988 & 1878 & 132 & & 3546 & 545 & 691 & 1687 & 330 & 2362 \\
1989 & 1784 & 108 & & 3586 & 520 & 782 & 1718 & 323 & 2142 \\
1990 & 1744 & 103 & 654 & 3114 & 612 & 1003 & 1946 & 389 & 2344 \\
1991 & 1876 & 108 & 739 & 3173 & 571 & 999 & 1881 & 386 & 2699 \\
1992 & 2066 & 200 & 387 & 2760 & 790 & 1798 & 1863 & 345 & 2810 \\
1993 & 2017 & 229 & 388 & 3370 & 864 & 1679 & 2024 & 352 & 3114 \\
1994 & 2314 & 287 & 479 & 3238 & 666 & 2165 & 1869 & 356 & 2790 \\
1995 & 2574 & 276 & 560 & 3449 & 646 & 2195 & 2103 & 378 & 2741 \\
1996 & 3593 & 322 & 973 & 4324 & 669 & 2273 & 2130 & 709 & 2950 \\
1997 & 3880 & 247 & 1107 & 4386 & 727 & 2509 & 2070 & 853 & 3357 \\
1998 & 3979 & 267 & 1171 & 4980 & 687 & 2526 & 2112 & 1055 & 3613 \\
\hline
\end{tabular}

Fonte: Ministério de Minas e Energia - MME(1999). ${ }^{1}$ O montante inclui o consumo próprio das usinas sucroalcooleiras e comercializado com as concessionárias. ${ }^{2}$ Refere-se às seguites fontes de geração: gás de cozinha, outros residuos e outras fontes secundárias. 
A principal vantagem da cogeração de energia pela cana-de-açúcar é o fato da safra da cultura coincidir com a época das secas, quando os reservatórios das hidrelétricas estão em níveis muito baixo, CPFL (1988).

Cohen (1998), cita vantagens do uso do bagaço na cogeração de energia elétrica: menor investimento em relação ao hidrelétrico; redução na importação de combustiveis fósseis; canaviais espalhados pelo território inteiro; redução dos investimentos em transmissão; maior confiabilidade no sistema elétrico nacional; geração de empregos diretos e indiretos; redução dos impactos ambientais.

Guilhon (1982), cita as vantagens da cana-de-açúcar em relação às demais biomassas, como sendo: lavoura organizada, custos e logísticas debitados do produto nobre, aproveitamento racional do bagaço com $74 \%$ de rendimento termoenergético, sem investimento agrícola.

Da potência total instalada, somente $700 \mathrm{Mw}$ estão sendo produzidos, sendo que $660 \mathrm{Mw}$ são consumidos no processo produtivo das usinas sucroalcooleiras e o restante, comercializado junto ao setor elétrico, ANEEL (2001). Segundo a mesma bibliografia, no Estado de São Paulo, o setor gera para consumo próprio entre $1.200 \mathrm{e}$ $1.500 \mathrm{Mw}, 40$ usinas produzem excedentes de $158 \mathrm{Mw}$ e a energia elétrica que vem da cana-de-açúcar já ajuda a iluminar diversas cidades. O potencial de geração de energia da agroindústria canavieira está em torno de 12 mil Mw e a potência total instalada no Brasil é de 70 mil Mw. Em 2002, em função de novos projetos, mais $300 \mathrm{Mw}$ devem ser adicionados e em curto prazo o setor poderá contribuir com quatro mil Mw adicionais.

Porém, atualmente, a cogeração representa apenas $3 \%$ da matriz energética do país. Em outros paises a cogeração tem maior representatividade, por exemplo, a Dinamarca chega aos $40 \%$, Holanda $28 \%$, Alemanha $15 \%$, Itália $12 \%$, EUA $7 \%$ e a Inglaterra com $5 \%$, segundo DNA DA CANA-DE-AÇÚCAR (1998).

\subsubsection{Considerações sobre o palhiço}

Tratando-se de biomassa de cana-de-açúcar e cogeração de energia, praticamente, todos os focos (e quase todas as bibliografias) estão voltados ao bagaço, subproduto da produção de álcool, e deixou-se de lado o palhiço, que, devido à colheita 
tradicional (corte manual), é queimado no campo ou, sob influência dos conceitos em plantio direto, é apenas utilizado como cobertura do solo.

Para Ripoli et al. (2003), "palha" tem sido a denominação genérica e errônea para o resíduo da colheita de cana-de-açúcar, sem queima, quando o correto tecnicamente seria "palhiço", porque tal material não se constitui apenas de folhas de cana com baixo grau de umidade, sendo constituído por folhas verdes, folhas secas, ponteiros, colmos e ou suas frações (perdas de colheita) e terra agregada a estes constituintes, trazendo benefícios ao sistema produtivo, melhorando as características químicas e físicas do solo, controlando paralelamente ervas daninhas e sendo uma excelente biomassa para uso na cogeração de energia. A mesma referência cita dados onde o palhiço deixado no campo pode alcançar valores de até trinta toneladas por hectare (base em peso úmido).

$\mathrm{Na}$ Tabela 8, estão apresentados dados sobre produtividade do palhiço, obtidos em bibliografia.

Tabela 8- Produtividades de palhiço encontradas em bibliografias consultadas

Autores Produtividade do Palhiço $\left(\right.$ t.ha $\left.^{-1}\right)$

Ripoli et al. (1990b)

9,70

Ripoli et al. (1991b)

21,60

Abramo Filho et al. (1993)

21,30

Molina Jr et al. (1995)

33,85

Ripoli et al. (1995a)

26,35

Ripoli et al. (1995b)

33,25

Furlani Neto et al. (1996)

13,61

Furlani Neto et al. (1997)

24,32

Bizuti (2003)

27,01

Sartori (2001)

14,40

Torresan (2003)

27,10

Franco (2003)

24,13 
Com o corte do canavial sem queima prévia, restará sobre o solo $1 / 5$ do peso total da cana na forma de folhas, palhas e pontas de colmo (Lopes 1970).

Segundo Urquiaga et al. (2001), a palha depositada anualmente no solo durante o sistema de colheita da cana-de-açúcar verde, apresenta uma produtividade que varia de 10 a 15 t.ha ${ }^{-1}$.

Lopez (1987), apresenta resultados de estudos realizados na Usina Central Romana, na República Dominicana. Esclarece que, após a colheita da cana-de-açúcar sem queima prévia de toda a área plantada (66.000 ha), o palhiço foi colhido e carregado manualmente. Esse material constitui-se de ponteiros e de folhas secas e que, logo após a operação de colheita, representou por volta de $30 \%$ do peso total da biomassa produzida. O menor valor encontrado foi de $15 \%$. O autor esclarece, ainda, que ocorrem variações desse percentual, em função das condições em que se desenvolveram os cultivos e das variedades utilizadas. Quanto à umidade do material, em dias ensolarados e em menos de uma semana, afirma que esta caiu para $30 \%$, em média, e em certos casos chegou a $20 \%$. Quanto ao Poder Calorífico Inferior (PCl) do material remanescente, apresentou em $4.180 \mathrm{kcal}^{\mathrm{Kg}}{ }^{-1}$, com base em peso seco e de $2.850 \mathrm{kcal} . \mathrm{Kg}^{-1}$, quando ele continha $30 \%$ de umidade. Apresenta resultados de desempenhos operacional e econômico de sistemas de recolhimento do material remanescente, para posterior utilização energética, conforme Tabela 9, afirmando que a maior limitação do palhiço se prende a sua baixa densidade, a qual, por sua vez, varia em função dos métodos de recolhimento e preparo para transporte.

Tabela 9- Resultados obtidos por Lopez (1987) sobre operações agrícolas envolvidas na manipulação de palhiço

\begin{tabular}{lcc}
\hline Operações & US $\$ . \mathrm{t}^{-1}$ & $\mathrm{t} \cdot \mathrm{h}^{-1}$ efetiva \\
\hline Enleiramento & 1,24 & 7,0 \\
Recolhimento-picamento & 2,93 & 5,7 \\
Transporte & 2,35 & - \\
Carregamento (grua) & 0,51 & - \\
\hline
\end{tabular}

Fonte: Lopez (1987).

O Jornal Cana (2000) informa que, experimentos realizados pela Seção de Projetos Mecânicos Agrícolas do Centro de Tecnologia Copersucar, em Piracicaba 
(SP), apontam para um total de palha produzida pelas variedades mais comuns de cana-de-açúcar que varia de 110 a $170 \mathrm{Kg}$ em matéria seca por tonelada colhida, quantidade que pode ser aproveitada por meio de sistemas de recolhimento e transporte até a industria.

Para Ripoli (2001), o palhiço desperta o interêsse dos canavieiros, uma vez que o equivalente energético dessa matéria-prima, gira em torno de 1,2 barris de petróleo por tonelada de material. Sendo esse palhiço, encontrado nos canaviais, na ordem de 9 a 32 t.ha $^{-1}$ com base em peso úmido $\mathrm{e}$, dependendo das condições da cultura, um hectare de canavial oferece entre 11 e 33 equivalentes barris de petróleo.

São Paulo possui, 2.200.000 ha de cana-de-açúcar plantada, dos quais $55 \%$ (1.210.000 ha) eram mecanizáveis. Considerando-se que $50 \%$ do palhiço (folha verde, ponteiro e palha), produzidos nessa área mecanizada, fossem usados para a produção de energia, resultariam em, aproximadamente, $25 \%$ do que o Brasil importou de petróleo em 1994, em termos de EBP (Equivalente barril de petróleo), com a vantagem de ser uma fonte renovável de energia, de acordo com Ripoli (1996).

Segundo Ripoli \& Ripoli (2000), o palhiço fornece uma média de energia por volta de $13.551 \mathrm{MJ}^{-1}$. Estimaram para o Brasil que este material, se recolhido e levado até as usinas e destilarias poderá gerar energia suficiente para abastecer $9,85 \times 10^{6}$ pessoas de consumo de baixa renda, por ano, enquanto que o bagaço que já é amplamente utilizado para produção energética, pode atender a $5,55 \times 10^{6}$ pessoas.

Partindo de resultados obtidos por vários autores brasileiros, Ripoli et al. (1990a), projetaram uma estimativa do potencial disponivel em um hectare de cana-de-açúcar, sem queima prévia, considerando-se uma produtividade agrícola de colmos de 70 t.ha $^{-1}$ e industrial de 75 L.t $^{-1}$ de etanol (Tabela 10). Esclarecem que, para o aproveitamento do palhiço como fonte energética, algumas dificuldades deverão ser enfrentadas, tais como: a sua baixa densidade in natura $\left(25 \mathrm{Kg} \cdot \mathrm{m}^{-3}\right)$; o seu teor de terra $(7 \%)$ e seu relativo e elevado grau de umidade (ponteiros $=76,9 \%$; folhas verdes $=65,7 \%$ e palhas=7,6 \%). Todavia, entendem que soluções técnicas advirão, pois a adoção de sistemas de colheita de cana sem queima prévia, beneficiará economicamente a agroindústria canavieira, diminuindo os impactos ambientais e fornecendo ao pais, nova fonte energética. 
Tabela 10- Estimativa do potencial disponivel em um hectare de cana-de-açúcar sem queima prévia

\begin{tabular}{lccc}
\hline \multicolumn{1}{c}{ Sub-produto } & Produção.ha $^{-1}$ & Energia Mcal.ha $^{-1}$ & Relação energia.produção $^{-1}$ \\
\hline Etanol & $5.250 \mathrm{~L}^{-} \mathrm{ha}^{-1}$ & 20.877 & 4,0 \\
Bagaço & 17,5 t.ha $^{-1}$ & 31.325 & 1,8 \\
Palhiço & 9.7 t.ha $^{1}$ & 22.166 & 2,3 \\
\hline Total & - & 74.368 & - \\
\hline
\end{tabular}

Adaptado: Ripoli et al. (1990a)

Ripoli (2001), estimou a origem da energia contida num hectare de cana-deaçúcar, a qual é apresentada na Figura 4.

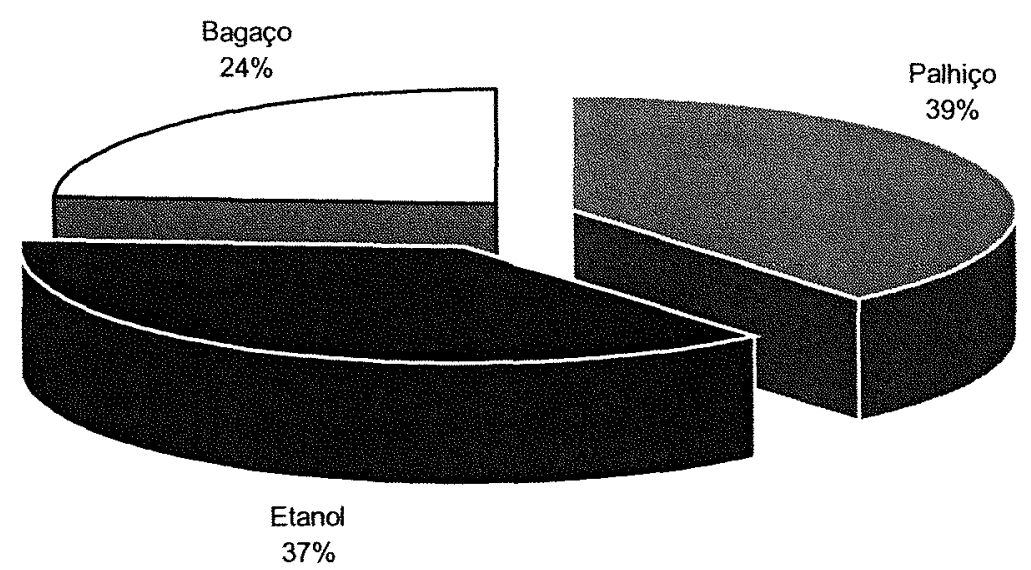

Figura 4- Origem da energia contida em um hectare de canavial (Ripoli, 2001)

O palhiço da cana, atualmente desperdiçado nos canaviais, tem um grande potencial de energia, assim como o bagaço, entre outros (Tabela 11). Composto principalmente, por folhas verdes, palha, ponteiro e frações de colmo, o palhiço, de maneira geral, é muito similar ao bagaço. O material oferece, como diferencial, menor umidade, o que provoca um ganho adicional de energia: a quantidade de energia disponivel depende dessa umidade; enquanto o bagaço apresenta $50 \%$, o palhiço apresenta de 30 a $60 \%$. "Recolhendo apenas $50 \%$ do palhiço por safra, a quantidade de energia obtida pode abastecer até sete milhões de pessoas em residências de baixo consumo", afirma Ripoli (2001). Portanto, o autor resume que o palhiço é mais uma fonte de energia que não está sendo aproveitada. 
Tabela 11- Comparação entre palhiço, bagaço e casca de arroz

\begin{tabular}{lcccc}
\hline Material & $\mathrm{Pu}$ & $\mathrm{A} \%$ & $\mathrm{Qt}$ & $\mathrm{Pd}$ \\
\hline Palhiço & 13,551 & 50 & 16,000 & $7,00 \times 10$ \\
Bagaço & 7,868 & 30 & 18,200 & $5,55 \times 10$ \\
Casca de Arroz & 15,401 & 80 & 0,257 & $0,26 \times 10$
\end{tabular}

Fonte: Ripoli (2001). Pu = Poder calorifico útil; $\mathrm{Qt}=$ Quantidade de palhiço; $\mathrm{A} \%=$ Quantidade de energia na palha; $\mathrm{Pd}=$ Número de pessoas que se beneficiam da energia/Ano.

\subsubsection{O recolhimento do palhiço}

Para Ripoli et al. (2003), o que se busca, em essência, atualmente com os estudos desenvolvidos para recolhimento do palhiço, são duas informações fundamentais: qual sistema apresenta o menor custo por tonelada e qual a percentagem de terra existente no palhiço posto na usina, porém mais importante que o custo de palhiço posto na usina por determinado sistema de recolhimento é saber o custo da energia na forma de palhiço posto na usina, seja em equivalente barril de petróleo, Kw etc. Afirmam ainda, que é necessário saber também, qual dos sistemas apresenta melhor eficiência energética. Informa que estudos em desenvolvimento por usinas e órgãos de pesquisa oficiais e privados estão centrados nas seguintes opções de recolhimento do palhiço: a granel, por meio de colhedoras de forragens; enfardamento prismático ou cilindrico; enfardamento por meio de prensas algodoeiras e colheita de cana integral, com as colhedoras operando com os sistemas de limpeza desligados.

A operação de recolhimento a granel do palhiço de cana-de-açúcar, inicia-se com o enleiramento do mesmo que, basicamente, é o processo de revolver o palhiço (para viabilizar a secagem) e enleirá-lo (para facilitar a coleta do material). Existem vários tipos de enleiramentos, dependendo dos equipamentos utilizados $\mathrm{e}$, tem-se como desvantagem, tornar-se mais uma operação agrícola, com todos os ônus que isto acarreta, pois esse palhiço permanece no solo dificultando os tratos culturais da soqueira tais como capinas, irrigação, adubação e colheita. Quando a cana é cortada, sem ser queimada, fica sobre o solo uma grande quantidade de palhiço, estimado em 15 t.ha $^{-1}$ de massa seca, que representa sobre o solo $1 / 5$ do peso total da cana na forma de palhiço (Lopes 1970). 
Ripoli et al. (2003), ao avaliarem a eficiência energética (\%) e a quantidade de terra arrastada (\%) do palhiço recolhido em três diferentes sistemas, obtiveram os respectivos valores: 99,22 \% e 1,39\% para a colheita integral, $96,41 \%$ e 4,50 \% para o palhiço colhido a granel e $91,45 \%$ e $0,63 \%$ para o palhiço enfardado. 


\subsection{Material e Métodos}

\subsubsection{Material}

\subsubsection{Máquinas}

Foram utilizadas as seguintes máquinas:

Ancinho de 4 discos verticais, marca DMB (Figura $5 \mathrm{E}$ ), com $50 \%$ das hastes, acoplado ao trator FORD, modelo $4 \times 2$ TDA, modelo 8639. Ancinho de dois discos horizontais (Figura 5A), marca JF (importado) acoplado ao trator Valmet, $4 \times 2$ TDA, modelo 885S. Colhedora de forragem, marca JF (importada), modelo FCT1050 (Figura 7B). Transbordo de capacidade para $8 \mathrm{t}$ líquidas, de rodado em tandem, com pneus de alta flutuação. Unidades de transporte (2), caçamba fechada. Caminhão oficina. Caminhão de abastecimento.

\subsubsection{Caracterização da cultura da cana-de-açúcar}

A variedade de cana-de-açúcar utilizada foi a SP $80-1842$, de $5^{\circ}$ corte, no espaçamento de $1,40 \mathrm{~m}$, com 11 meses, em latossolo roxo, declividade de $6 \%$. Talhões 48 a 51 (face de exposição SE) e 57 (face de exposição NE), apresentando uma produtividade média de palhiço da ordem de $14,75 \mathrm{t} . h a^{-1}$. Área pertencente ao Grupo COSAN, Usina Costa Pinto localizada entre as coordenadas geográficas de latitude $22^{\circ}$ $40^{\circ} 30^{\prime \prime} \mathrm{S}$ e longitude $47^{\circ} 36^{\circ} 38^{\prime \prime} \mathrm{W}$ com 580 metros de altitude, na cidade de Piracicaba, SP.

\subsubsection{Equipamentos de mensuração}

Para as medições efetuadas no campo, foram utilizados: Dois cronômetros digitais, marcas Casio e Spalding, com acurácia de 0,1 s. Célula de carga marca Kyowa, capacidade máxima de leitura de $1 \mathrm{t}$., e indicador digital. Trena de $50 \mathrm{~m}$, com fundo de escala de $10^{-2} \mathrm{~m}$. Quatro balanças móveis, com capacidade de leitura unitária de $4,5 \mathrm{t}$ com fundo de escala de $2 \mathrm{Kg}$ e indicador digital. Bureta graduada de $0,5 \mathrm{~L}$ e fundo de escala de 0,01 L. Para as medições de laboratório: Balança Metler, capacidade de leitura de $10^{-6} \mathrm{Kg}$ e indicador digital. Estufa marca Fanen, bateria de peneiras. 


\subsubsection{Outros utensílios}

Estrutura quadricular de ferro com $1 \mathrm{~m}$ de lado, tripé de ferro para suporte da célula de carga, ganchos de ferro, cordas, sacos plásticos transparentes, sacos plásticos (tipo sacaria para açúcar), sacos de papel, fita crepe, latas de alumínio com tampas (coleta de amostras de solo), nível de bolha, facões, estacas de madeira e tocos de madeira, correntes de ferro, macaco hidráulico, três baterias elétricas de $12 \mathrm{v}$, tambores plásticos, cadeiras, mesa, barraca de nylon.

\subsubsection{Métodos}

Para se avaliar o comportamento de ancinhos e de uma recolhedora de forragem operando sobre palhiço de cana-de-açúcar foram considerados duas condições (tratamentos T1 e T2) de enleiramento. Tratamento T1: Com o ancinho rotativo horizontal, marca JF (Figuras 5A e 5D) realizando enleiramento de 1,5 leira (metade da leira sobreposta a uma anterior) (Figuras 5B e 5C). Tratamento T2: Com o ancinho rotativo vertical (marca DMB) realizando o enleiramento duplo (1 leira sobreposta a anterior) conforme Figura 5E.

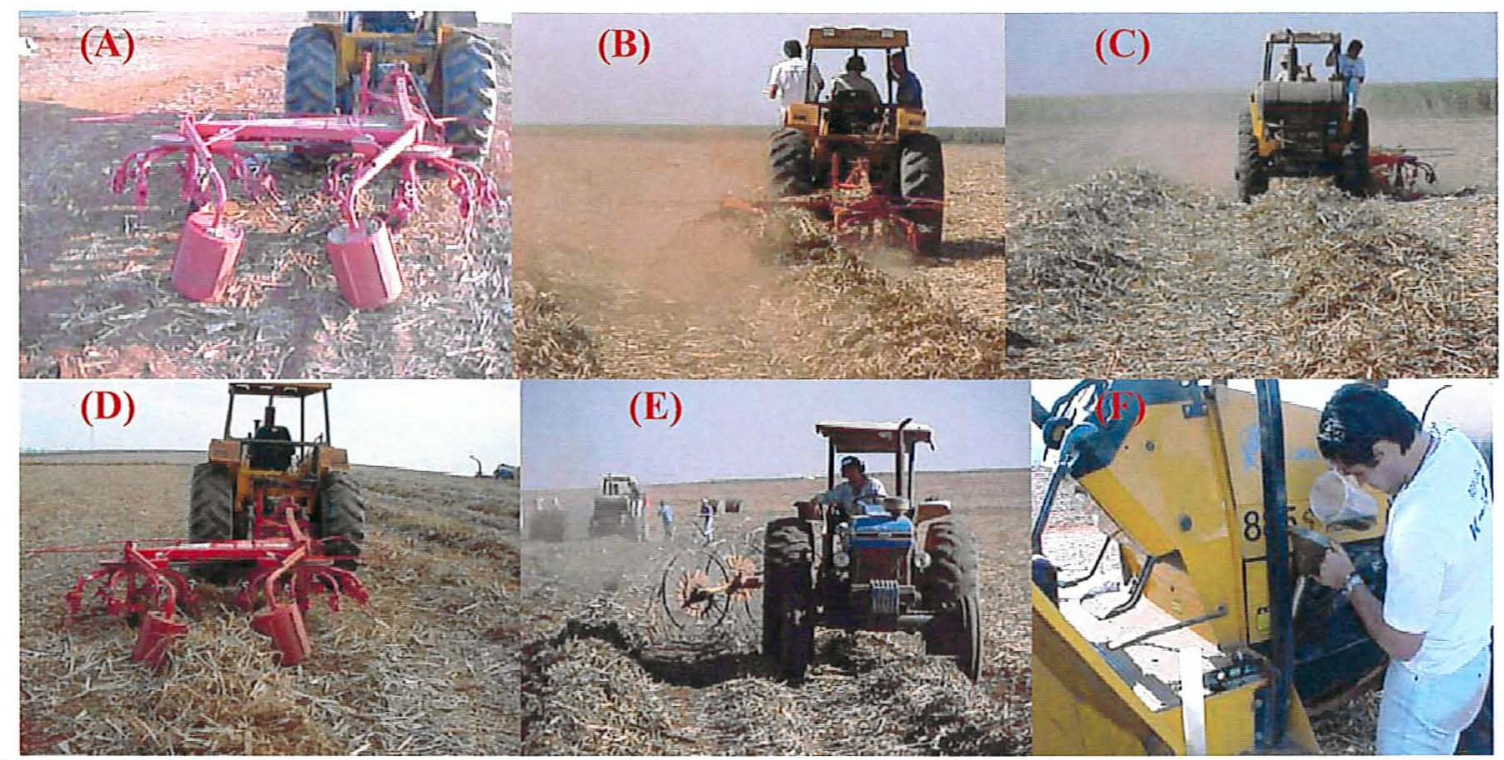

Figura 5- (A) Vista traseira do ancinho marca JF; (B) Vista traseira do ancinho $\mathrm{JF}$, formando a primeira leira; (C) Vista frontal do ancinho JF remontando meia leira sobre a anterior; (D) ancinho JF realizando a primeira passada; $(E)$ ancinho DMB remontando uma leira; $(F)$ reabastecimento completo do tanque de combustivel do trator 
Depois de enleirado o material foi recolhido e pesado, ainda no transbordo, em local nivelado utilizando-se de quatro balanças sob os pneus.

Em cada tratamento foram realizadas 08 repetições com as seguintes variáveis: Capacidades Efetiva e Operacional $\left(\mathrm{t} . \mathrm{h}^{-1}\right)$ e $\left(\mathrm{t} . \mathrm{ha}^{-1}\right)$; consumo de combustivel e o custo das operações de enleiramento e recolhimento $\left(\right.$ L..$\left.^{-1}\right)$ e $\left(L . h a^{-1}\right)$; umidade do palhiço recolhido e a de terra arrastada no material manipulado pelos ancinhos e pela recolhedora (\%); massas de palhiço não manipuladas (perdas) pelas operações; poder calorífico útil disponível (EBP) e a eficiência energética do processo de recolhimento $(\%)$.

\subsubsection{Determinação de massa, umidade e terra agregada do palhiço "in natura e} algumas caracteristicas do solo.

Após a colheita mecanizada da cana-de-açúcar e antes do início das operações de enleiramento e recolhimento, na área a ser estudada foram tomadas 5 amostras de solo de forma casualizada, no perfil de 0 a $0,05 \mathrm{~m}$, as quais foram hermeticamente fechadas e acondicionadas em latas de alumínio. As amostras foram analisadas no laboratório de máquinas agricolas da ESALQ/USP, onde foram determinadas suas porcentagens de umidade, em estufa, por 48 horas, na temperatura entre $105^{\circ}-110^{\circ} \mathrm{C}$. Uma amostra composta resultante destas amostras iniciais foi preparada para obtenção da granulometria do solo aplicando-se o método Steel \& Bradfield (1934), que visa a obtenção da fração argila. Tais análises tiveram por objetivo conhecer as condições de solo da área de estudo, sobre as quais as máquinas operariam.

Para este estudo entende-se como palhiço "in natura" o palhiço existente no solo proveniente da colheita mecanizada de cana-de-açúcar sem queima prévia, antes do inicio das operações de enleiramento e recolhimento.

Coletou-se aleatóriamente em sacos plásticos, posteriormente vedados e codificados, 6 amostras compostas do palhiço "in natura", tomando-se o cuidado de recolher apenas palha que não estava em contato direto com o solo. Essas amostras foram levadas ao laboratório de máquinas agricolas da ESALQ/USP, onde foram pesadas e secas em estufa durante 48 horas a temperatura de $65^{\circ} \mathrm{C}$. Com base na 
diferença do peso úmido e do peso seco foi calculada a umidade presente no material, utilizando-se a equação 3 :

$$
\text { UPin }(\%)=((M U-M S) / M U) \cdot 100
$$

Sendo:

$$
\begin{aligned}
& \text { UPin = Umidade do palhiço in natura }(\%) \\
& M U=\text { Massa úmida da amostra }\left(\mathrm{Kg} \cdot \mathrm{m}^{-2}\right) \\
& \mathrm{MS}=\text { Massa seca da amostra }\left(\mathrm{Kg} \cdot \mathrm{m}^{-2}\right)
\end{aligned}
$$

\subsubsection{Enleiramento}

\subsection{Capacidades efetiva e operacional e o consumo de combustível da operação de enleiramento}

Durante a operação de enleiramento, para todas as repetições, foram anotadas as distâncias percorridas (em metros) e suas respectivas tomadas de tempo (em segundos), inclusive manobras, de acordo com a metodologia proposta por Ripoli (1991a).

Antes da operação de enleiramento e depois desta, foram retiradas 8 amostras com $1 \mathrm{~m}^{2}$ cada uma de palhiço que estava sobre o solo sendo estas,consideradas como repetições.

Estas amostras foram coletadas em campo, pesadas no laboratório de máquinas agrícolas da ESALQ/USP e depois descartadas, originando a equação 4.

$$
M P E=(M P A E-M P D E) .10
$$

Sendo:

MPE $=$ Massa de palhiço enleirada $\left(\right.$ t. $\left.h a^{-1}\right)$.

MPAE = Massa de palhiço antes da operação de enleiramento $\left(\mathrm{Kg} \cdot \mathrm{m}^{-2}\right)$.

MPDE $=$ Massa de palhiço depois da operação de enleiramento $\left(\mathrm{Kg} \cdot \mathrm{m}^{-2}\right)$.

Para obter a capacidade de campo efetiva e a operacional de enleiramento em ha. $h^{-1}$ utilizou-se respectivamente as equações 5 e 6 .

$\mathrm{CEE}_{1}=((\mathrm{DIST} . \mathrm{LARG}) / \mathrm{TEE}) \cdot 0,36$

Sendo:

$\mathrm{CEE}_{1}=$ Capacidade efetiva de enleiramento $\left(\right.$ ha. $\left.\mathrm{h}^{-1}\right)$.

DIST = Distância percorrida $\left(\right.$ m.repetição $\left.0^{-1}\right)$. 
LARG = Largura média efetiva $(m)$.

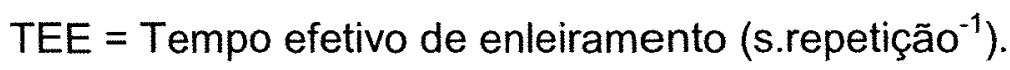

$\mathrm{COE}_{1}=((\mathrm{DIST} \cdot \mathrm{LARG}) / \mathrm{TOE}) \cdot 0,36$

Sendo:

$\mathrm{COE}_{1}=$ Capacidade operacional de enleiramento $\left(\right.$ ha. $\left.\mathrm{h}^{-1}\right)$.

DIST = Distância percorrida $\left(\right.$ m.repetição $\left.{ }^{-1}\right)$.

LARG $=$ Largura média efetiva $(m)$.

TOE = Tempo operacional de enleiramento (s.repetição ${ }^{-1}$ ).

Para a capacidade de campo efetiva e de enleiramento em $t \cdot h^{-1}$ utilizou-se o tempo efetivo de enleiramento, conforme a equação 7 :

$$
\mathrm{CEE}_{2}=((\mathrm{AE} \cdot \mathrm{MPE}) / \mathrm{TEE}) \cdot 3,6
$$

Sendo:

$\mathrm{CEE}_{2}=$ Capacidade efetiva de enleiramento $\left(\mathrm{t} \cdot \mathrm{h}^{-1}\right)$.

$\mathrm{AE}=$ Área enleirada por repetição $\left(\mathrm{m}^{2}\right.$.repetição $\left.{ }^{-1}\right)$.

$\mathrm{MPE}=$ Massa de palhiço enleirada $\left(\mathrm{Kg} \cdot \mathrm{m}^{-2}\right)$.

$\mathrm{TEE}=$ Tempo efetivo de enleiramento $\left(\right.$ s.repetição $\left.{ }^{-1}\right)$.

Para a capacidade operacional utilizou-se o tempo total, isto é, o tempo enleirando mais os tempos de manobra e os tempos de parada (embuchamentos), de acordo com equação 8:

$\mathrm{COE}_{2}=((\mathrm{AE} \cdot \mathrm{MPE}) / \mathrm{TOE}) \cdot 3,6$

Sendo:

$\mathrm{COE}_{2}=$ Capacidade operacional de enleiramento $\left(\mathrm{t} . \mathrm{h}^{-1}\right)$.

$\mathrm{AE}=$ Área enleirada por repetição $\left(\mathrm{m}^{2} \cdot\right.$.repetição $\left.{ }^{-1}\right)$.

$\mathrm{MPE}=$ Massa de palhiço enleirada $\left(\mathrm{Kg} \cdot \mathrm{m}^{-2}\right)$.

$\mathrm{TOE}=$ Tempo operacional de enleiramento $\left(\right.$ s.repetição $\left.{ }^{-1}\right)$.

Para o cálculo das velocidades de enleiramento efetiva e operacional utilizou-se da relação entre a distância percorrida por repetição pelo conjunto mecanizado durante a operação de enleiramento (Figura 6) e o seu respectivo tempo necessário para conclusão do percurso, conforme as equações 9 e 10 :

$\mathrm{VEE}=(\mathrm{DIST} / \mathrm{TEE}) \cdot 3,6$

Sendo: 
VEE $=$ Velocidade efetiva de enleiramento $\left(\mathrm{km} \cdot \mathrm{h}^{-1}\right)$.

DIST $=$ Distância percorrida $\left(m \cdot\right.$ repetição $\left.{ }^{-1}\right)$.

TEE $=$ Tempo efetivo de enleiramento $\left(\right.$ s.repetição $\left.{ }^{-1}\right)$.

VOE $=($ DIST $/ T O E) \cdot 3,6$

Sendo:

VOE $=$ Velocidade operacional de enleiramento $\left(\mathrm{km} \cdot \mathrm{h}^{-1}\right)$.

DIST = Distância percorrida $\left(m \cdot\right.$ repetição $\left.0^{-1}\right)$.

TOE $=$ Tempo operacional de enleiramento $\left(\right.$ s.repetição $\left.{ }^{-1}\right)$.

Para o consumo de combustivel na operação de enleiramento, foram obtidos em cada uma das repetições as distâncias percorridas (em metros) e os tempos gastos (em segundos). O volume de combustível foi obtido ao final de cada tratamento, pois foi impraticável determiná-lo por repetição.

A seqüência de repetições de enleiramento, conforme Figura 6, iniciava-se com o tanque de combustivel do trator totalmente cheio, sendo que este encontrava-se em posição nivelada e plana (Figura $5 F$ ) para que se evitasse a formação de bolhas dentro do tanque, o que poderia mascarar o consumo obtido. Ao final do tratamento, completava-se o tanque com uma bureta graduada obtendo-se assim, o consumo de combustível gasto ao longo das repetições.

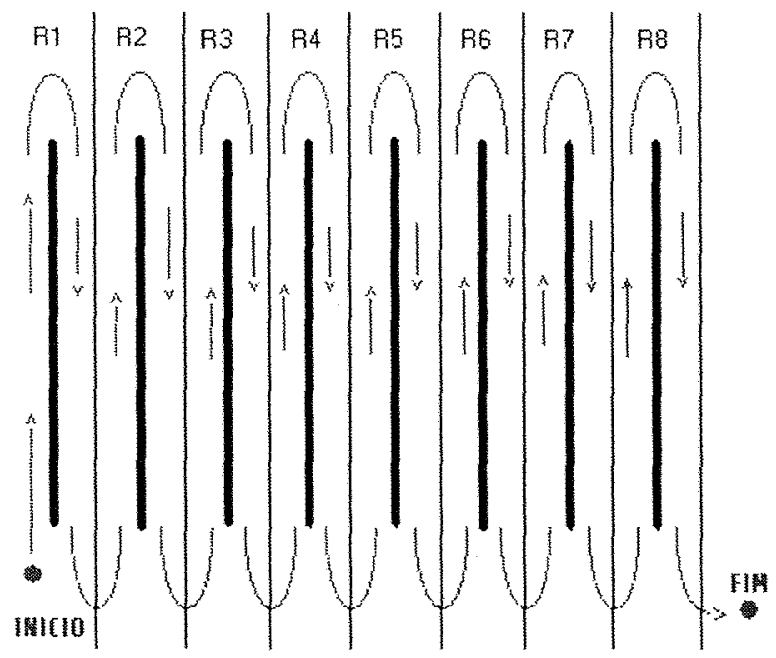

Figura 6- Esquema de enleiramento onde ida e volta formam uma repetição (uma leira)

Posteriormente, calculou-se o consumo médio de combustivel por repetição na operação de enleiramento. 
O consumo médio efetivo e operacional de enleiramento em L.repetição ${ }^{-1}$ foi calculado por meio das equações 11 e 12 respectivamente.

$\mathrm{CMEE}=\mathrm{CA}$. $($ TEE $/ 3600)$

Sendo:

$\mathrm{CMEE}=$ Consumo médio efetivo no enleiramento $\left(\right.$ L.repetição $\left.{ }^{-1}\right)$.

$\mathrm{CA}=$ Consumo aferido $\left(\mathrm{L} \cdot \mathrm{h}^{-1}\right)$.

$\mathrm{TEE}=$ Tempo efetivo de enleiramento (s.repetição ${ }^{-1}$ ).

$\mathrm{CMOE}=\mathrm{CA} .(\mathrm{TOE} / 3600)$

Sendo:

$\mathrm{CMOE}=$ Consumo médio operacional no enleiramento $\left(\right.$ L.repetição $\left.{ }^{-1}\right)$.

$\mathrm{CA}=$ Consumo aferido $\left(\right.$ L. $\left.\mathrm{h}^{-1}\right)$.

TOE $=$ Tempo operacional de enleiramento $\left(\right.$ s.repetição $\left.{ }^{-1}\right)$.

O consumo de combustível efetivo e operacional do enleiramento em L.ha ${ }^{-1}$ foi obtido utilizando-se as equações 11 e 12 de maneira a gerar as equações 13 e 14 a seguir.

$\mathrm{CONEE}_{1}=(\mathrm{CMEE} / \mathrm{AE}) \cdot 10000$

Sendo:

$\operatorname{CONEE}_{1}=$ Consumo efetivo na operação de enleiramento $\left(L \cdot \mathrm{ha}^{-1}\right)$.

$\mathrm{CMEE}=$ Consumo médio efetivo no enleiramento $\left(\right.$ L.repetição $\left.{ }^{-1}\right)$.

$\mathrm{AE}=$ Área enleirada por repetição $\left(\mathrm{m}^{2} \cdot\right.$ repetição $\left.^{-1}\right)$.

$\mathrm{CONOE}_{1}=(\mathrm{CMOE} / \mathrm{AE}) \cdot 10000$

Sendo:

$\mathrm{CONOE}_{1}=$ Consumo operacional na operação de enleiramento $\left(L \cdot \mathrm{ha}^{-1}\right)$.

$\mathrm{CMOE}=$ Consumo médio operacional no enleiramento (L.repetição ${ }^{-1}$ ).

$\mathrm{AE}=$ Área enleirada por repetição $\left(\mathrm{m}^{2}\right.$.repetição $\left.{ }^{-1}\right)$.

Para se determinar o consumo efetivo e operacional de enleiramento em L. $\mathrm{t}^{-1}$, utilizamos as equações 15 e 16 respectivamente.

$\mathrm{CONEE}_{2}=\mathrm{CONEE}_{1} /(\mathrm{MPE}, 10)$

Sendo:

CONEE $_{2}=$ Consumo efetivo na operação de enleiramento $\left(L^{-1} t^{-1}\right)$.

CONEE $_{1}=$ Consumo efetivo na operação de enleiramento (L.ha $\left.{ }^{-1}\right)$. 
MPE = Massa de palhiço enleirada $\left(\mathrm{Kg}_{\mathrm{m}} \mathrm{m}^{-2}\right)$.

$\mathrm{CONOE}_{2}=\mathrm{CONOE}_{1} /(\mathrm{MPE}$. 10)

Sendo:

$\mathrm{CONOE}_{2}=$ Consumo operacional na operação de enleiramento (L. $\left.\mathrm{t}^{-1}\right)$.

$\mathrm{CONOE}_{1}=$ Consumo operacional na operação de enleiramento (L.ha $\left.{ }^{-1}\right)$.

MPE $=$ Massa de palhiço enleirada $\left(\mathrm{Kg}^{-\mathrm{m}^{-2}}\right)$.

\subsubsection{Recolhimento}

Para a operação de recolhimento do palhiço enleirado (Figuras 7C e 7D), em todas as repetições, foram anotadas as distâncias percorridas (em metros) e suas respectivas tomadas de tempo (em segundos), inclusive manobras, de acordo com a metodologia proposta por Ripoli (1991a).

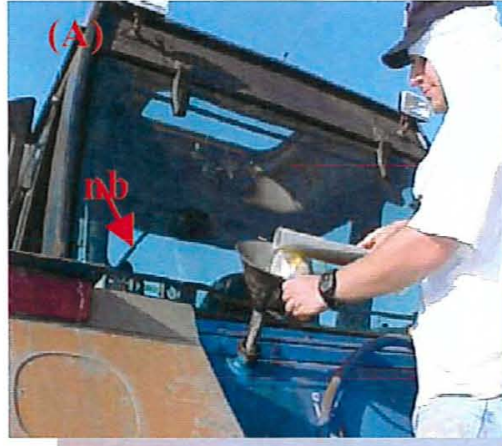

(D)

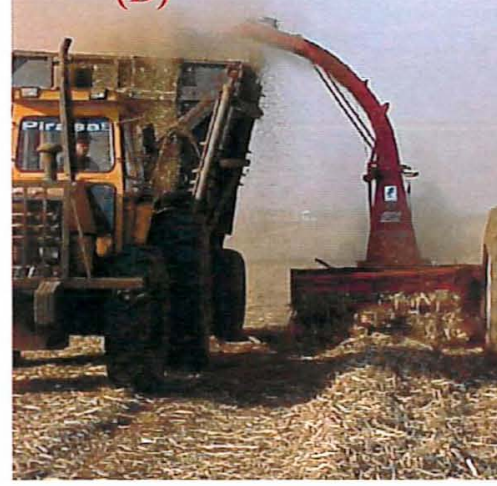

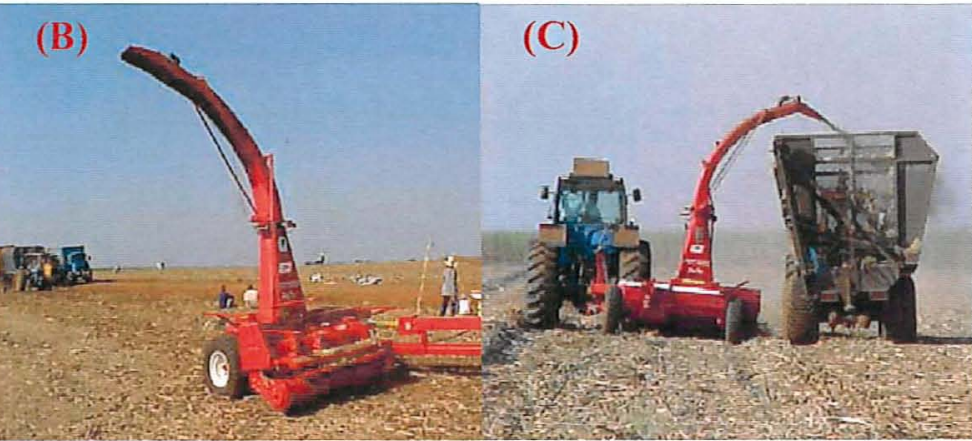

(E)

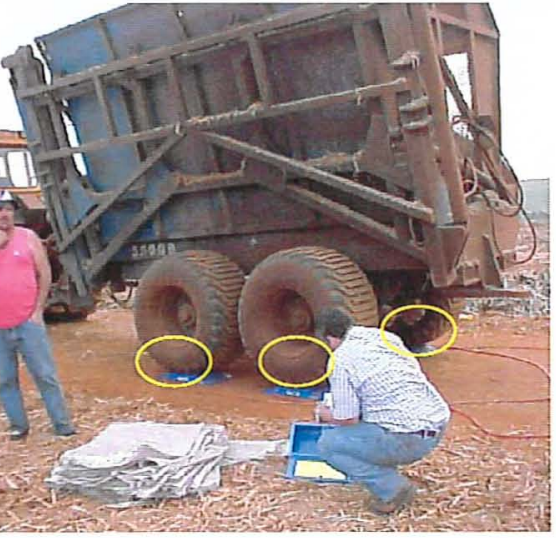

Figura 7- (A) Abastecimento para a operação de recolhimento, $(n b)=$ nível de bolha; (B) recolhedora JF; (C) recolhimento, vista traseira; (D) recolhimento vista frontal; $(E)$ pesagem de uma repetição (2 fileiras de material enleirado) 
Ao término de cada repetição, o transbordo deslocava-se para um carreador nivelado, sendo posicionado (Figura $7 E$ ) sobre as quatro balanças (uma para cada pneu) para tomada de sua massa bruta sem, até o momento, levar-se em consideração a transferência de massa ocorrida por ele (o transbordo) estar acoplado à barra de tração da fonte de potência.

\subsection{Determinação da transferência de massa da carreta para o trator}

Ao final de cada repetição de recolhimento, o transbordo acoplado a um trator era levado até um local plano onde, encontravam-se as balanças para pesar o transbordo. Para obter-se a carga líquida do material recolhido e carregado no transbordo, inicialmente obteve-se a massa bruta real do mesmo sendo necessário determinar, em porcentagem, qual foi a transferência de massa ocorrida entre o transbordo e o trator acoplado por ocasião das pesagens de cada repetição. Para obterse a massa bruta real do transbordo, ou seja, eliminando-se a transferência de massa ocorrida enquanto este se encontrava acoplado ao trator, utilizou-se de um guincho hidráulico para suspender e separar o acoplamento (Figura 8A) e depois, por meio de calços de madeira (Figura $8 \mathrm{C}$ ) travou-se os balancins das rodas (eixo tandem) a fim de tornar a unidade de transporte desacoplada e estável (Figura 8B). O mesmo procedimento ocorreu para a tara da unidade.

Determinou-se assim, a massa líquida colhida conforme a equação 17.

$$
M L=((M B-T T) \cdot 1,0972)-7120
$$

Sendo:

$\mathrm{ML}=$ massa líquida de matéria-prima colhida por repetição $(\mathrm{Kg})$.

$\mathrm{MB}=$ massa bruta do transbordo com matéria-prima e sem descontar a transferência de massa $(\mathrm{Kg})$.

$\mathrm{TT}=$ tara dos dois tambores metálicos de amostragem, contidos dentro do transbordo, junto com a matéria -prima colhida $(\mathrm{Kg})$.

1,0972 = corresponde a 9,72 \% médio de transferência de massa acoplado. $7120=$ tara do transbordo $(\mathrm{Kg})$. 


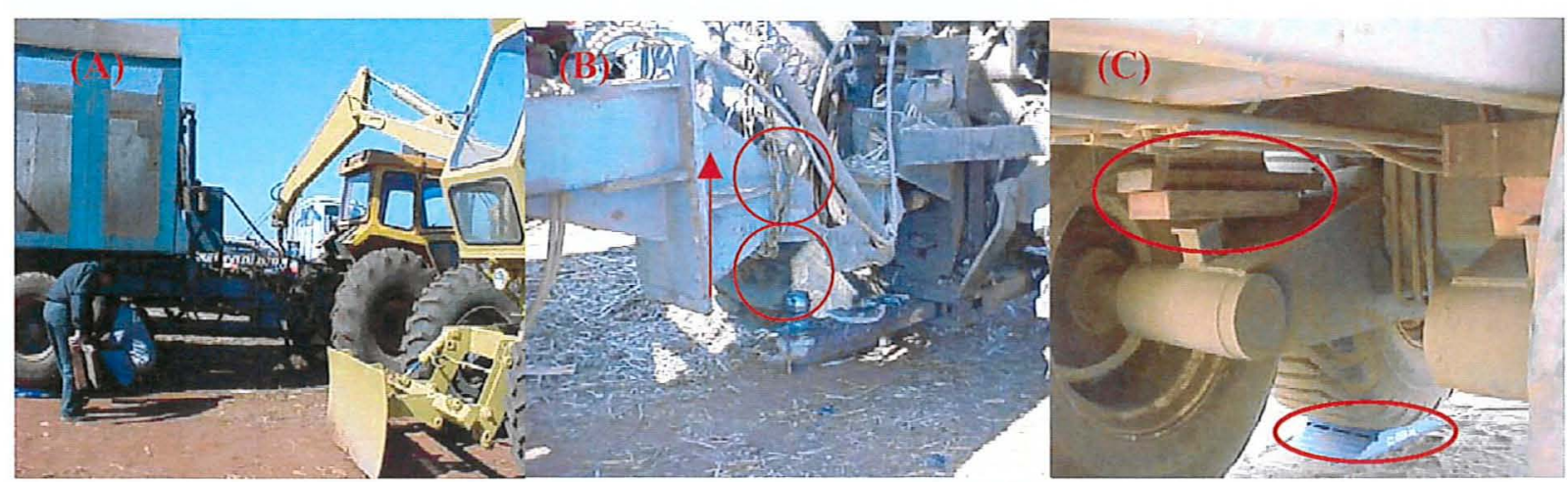

Figura 8- (A) Utilização de guincho para separar o transbordo do trator; (B) barra de tração separada do transbordo; (C) pedaços de madeira entre os balancins e a base da caçamba

\subsection{Capacidades Efetiva e Operacional e o consumo de combustível da Operação de recolhimento}

Para a capacidade efetiva de recolhimento em t. $\mathrm{h}^{-1}$ utilizou-se apenas o tempo efetivo da operação (tempo recolhendo) de acordo com a equação 18:

$\mathrm{CER}_{1}=(\mathrm{ML} / \mathrm{TER}) \cdot 3,6$

Sendo:

$\mathrm{CER}_{1}=$ Capacidade efetiva de recolhimento $\left(\mathrm{t} \cdot \mathrm{h}^{-1}\right)$.

$\mathrm{ML}=$ Massa líquida de matéria-prima colhida $\left(\mathrm{Kg}\right.$ repetição $\left.{ }^{-1}\right)$.

TER $=$ Tempo efetivo de recolhimento $\left(\right.$ s.repetição $\left.{ }^{-1}\right)$.

Para a capacidade operacional de recolhimento em t.h $\mathrm{h}^{-1}$ utilizou-se o tempo total, isto é, o tempo recolhendo mais o tempo de manobras e tempos de paradas, (embuchamentos), de acordo com a equação 19:

$\mathrm{COR}_{1}=(\mathrm{ML} / \mathrm{TOR}) \cdot 3,6$

Sendo:

$\mathrm{COR}_{1}=$ Capacidade operacional de recolhimento $\left(\mathrm{t} \cdot \mathrm{h}^{-1}\right)$.

$\mathrm{ML}=$ Massa líquida de matéria-prima colhida $\left(\mathrm{Kg}\right.$ repetição $\left.{ }^{-1}\right)$.

TOR= Tempo operacional de recolhimento $\left(\right.$ s.repetição ${ }^{-1}$ ).

Para as capacidades efetiva e operacional de recolhimento em ha. $\mathrm{h}^{-1}$ utilizaramse as equações 20 e 21.

$\mathrm{CER}_{2}=(\mathrm{AT} / \mathrm{TER}) \cdot 0,36$

Sendo:

$\mathrm{CER}_{2}=$ Capacidade efetiva de recolhimento $\left(\right.$ ha. $\left.\mathrm{h}^{-1}\right)$. 
AT = Área do tratamento $\left(\mathrm{m}^{2} \cdot\right.$ repetição $\left.{ }^{-1}\right)$.

$\mathrm{TER}=$ Tempo efetivo de recolhimento $\left(\right.$ s.repetição $\left.{ }^{-1}\right)$.

$\mathrm{COR}_{2}=(\mathrm{AT} / \mathrm{TOR}) \cdot 0,36$

Sendo:

$\mathrm{COR}_{2}=$ Capacidade operacional de recolhimento $\left(\right.$ ha. $\left.\mathrm{h}^{-1}\right)$.

AT = Área do tratamento $\left(\mathrm{m}^{2}\right.$.repetição $\left.{ }^{-1}\right)$.

TOR $=$ Tempo operacional de recolhimento $\left(\right.$ s.repetição $o^{-1}$ ).

Sendo que, o cálculo para a área recolhida, utilizada nas equações 20 e 21 acima, está demonstrado na equação 22.

$A R=(D I S T . L M L)$

Sendo:

$\mathrm{AR}=$ Área de recolhimento $\left(\mathrm{m}^{2}\right.$.repetição $\left.{ }^{-1}\right)$.

DIST = Distância percorrida $\left(\right.$ m.repetição $\left.{ }^{-1}\right)$.

$\mathrm{LML}=$ Largura média da leira $(\mathrm{m})$.

Para o cálculo das velocidades de recolhimento efetiva e operacional utilizou-se a relação entre as distâncias percorridas por repetição durante a operação de recolhimento com seus respectivos tempos efetivo e operacional necessários para conclusão do percurso, conforme as equações 23 e 24.

$\mathrm{VER}=(\mathrm{DIST} / \mathrm{TER}), 3,6$

Sendo:

VER $=$ Velocidade efetiva de recolhimento $\left(\mathrm{km} \cdot \mathrm{h}^{-1}\right)$.

DIST = Distância percorrida $\left(\right.$ m.repetição $\left.{ }^{-1}\right)$.

$\mathrm{TER}=$ Tempo efetivo de recolhimento $\left(\right.$ s.repetição $\left.{ }^{-1}\right)$.

VOR $=($ DIST $/$ TOR $) \cdot 3,6$

Sendo:

VOR $=$ Velocidade operacional de recolhimento $\left(\mathrm{km} \cdot \mathrm{h}^{-1}\right)$.

DIST = Distância percorrida $\left(\right.$ m.repetição $\left.0^{-1}\right)$.

TOR $=$ Tempo operacional de recolhimento $\left(\right.$ s.repetição $\left.{ }^{-1}\right)$.

Para o cálculo do consumo de combustível (L.repetição ${ }^{-1}$ ) na operação de recolhimento mensurou-se o consumo operacional (CONOR) mediante a leitura direta em cada repetição (Figura 7A). Com estes dados em mãos foi possível calcular o 
consumo efetivo do combustivel no recolhimento, sendo que a distância percorrida foi pré-mensurada em $340 \mathrm{~m}$ para o tratamento 1 (JF) e $320 \mathrm{~m}$ para o tratamento 2 (DMB).

$\mathrm{CONER}_{1}=(\mathrm{TER} \cdot \mathrm{CONOR}) / \mathrm{TOR}$

Sendo:

$\mathrm{CONER}_{1}=$ Consumo efetivo de recolhimento $\left(\right.$ L.repetição $\left.{ }^{-1}\right)$.

TER $=$ Tempo efetivo de recolhimento $\left(s\right.$. repetição ${ }^{-1}$ ).

CONOR $=$ Consumo operacional de recolhimento (L.repetição $\left.{ }^{-1}\right)$.

TOR $=$ Tempo operacional de recolhimento $\left(\right.$ s.repetição $\left.{ }^{-1}\right)$.

Dessa forma, cada repetição de recolhimento abrangeu duas fileiras de palhiço enleirado, conforme Figura 9.

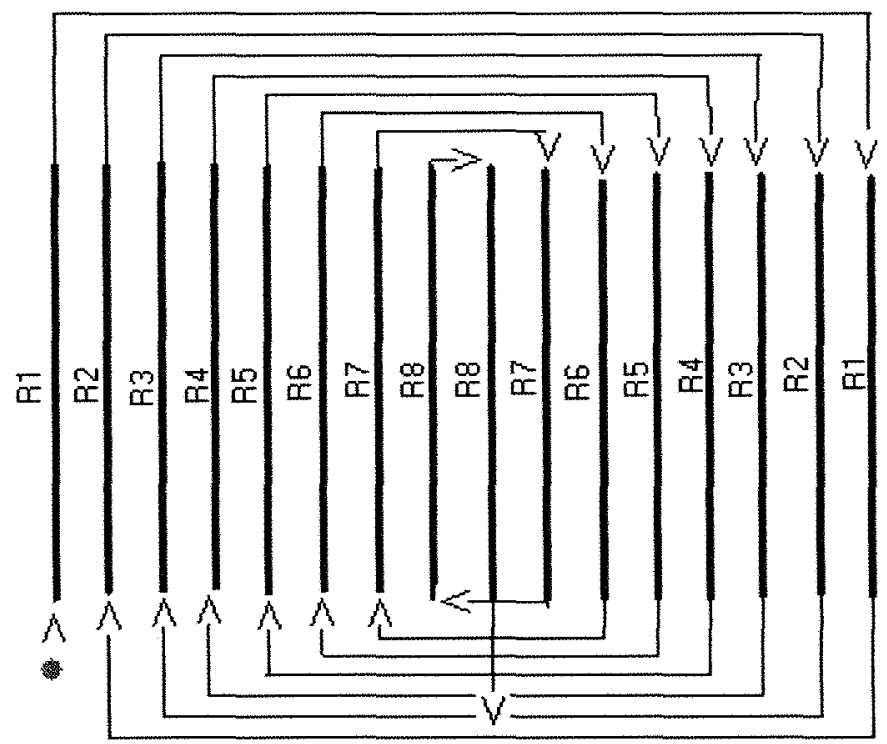

Figura 9- Esquema de recolhimento onde, cada repetição corresponde a duas leiras

Para o cálculo do consumo de combustível na operação de recolhimento em L.t ${ }^{-1}$ utilizou-se a razão entre o consumo de combustivel na operação de recolhimento em litros por repetição e a massa líquida de matéria-prima colhida, conforme equação 26.

$\mathrm{CONER}_{2}=\left(\mathrm{CONER}_{1} / \mathrm{ML}\right) \cdot 1000$

Sendo:

CONER $_{2}=$ Consumo de combustível no recolhimento $\left(\right.$ L. $\left.t^{-1}\right)$.

CONER $_{1}=$ Consumo de combustível no recolhimento (L.repetição ${ }^{-1}$ ).

$\mathrm{ML}=$ Massa líquida de matéria-prima colhida $\left(\mathrm{Kg}\right.$.repetição $\left.{ }^{-1}\right)$. 
Para o consumo de combustivel no recolhimento em L.ha ${ }^{-1}$, utilizou-se a equação 27.

$\mathrm{CONER}_{3}=\left(\mathrm{CONER}_{2} \cdot((\mathrm{ML} / \mathrm{AR}) \cdot 10)\right)$

Onde:

CONER $_{3}=$ Consumo de combustivel no recolhimento $\left(\right.$ L.ha $\left.{ }^{-1}\right)$.

CONER $_{2}=$ Consumo de combustivel no recolhimento $\left(L . t^{-1}\right)$.

$\mathrm{ML}=$ Massa líquida de matéria-prima colhida $\left(\mathrm{Kg}\right.$.repetição $\left.{ }^{-1}\right)$.

$\mathrm{AR}=$ Área recolhida $\left(\mathrm{m}^{2}\right.$.repetição $\left.{ }^{-1}\right)$.

\subsubsection{Determinação de massas de palhiço não manipuladas (perdas) pelas operações avaliadas.}

Para cada repetição de recolhimento (duas leiras), foram coletadas 8 amostras de palhiço remanescente, inicialmente para se quantificar o palhiço remanescente após o enleiramento que corresponde a área coberta pelo ancinho porém, fora da leira produzida (Figura 10A e 10B) e antes do recolhimento na chamada "entre leiras". Após a operação de recolhimento, coletou-se mais 8 amostras do palhiço remanescente sendo que, desta vez, sobre onde estava a leira (Figura 10D). Destacando-se sempre que todas as amostras foram casualizadas e delimitadas por um quadrado de ferro de $1 \mathrm{~m}^{2}$. (Figura 10C).

Para a transformação de cada amostra de perda, de área de $1 \mathrm{~m}^{2}$, na unidade t. ha ${ }^{-1}$, tanto para o material não enleirado como para o material não recolhido, ou seja, o palhiço que permaneceu no campo, sobre o terreno, nas entreleiras e nas leiras após as operações de enleiramento e recolhimento respectivamente, adotou-se o seguinte critério (Figura 11): Sendo DL a distancia média (de 6 leituras) obtidas entre leiras e sendo LL a largura média (de 6 leituras) de leira, determinou-se a percentagem da área na qual o ancinho operou, para formar a leira. 


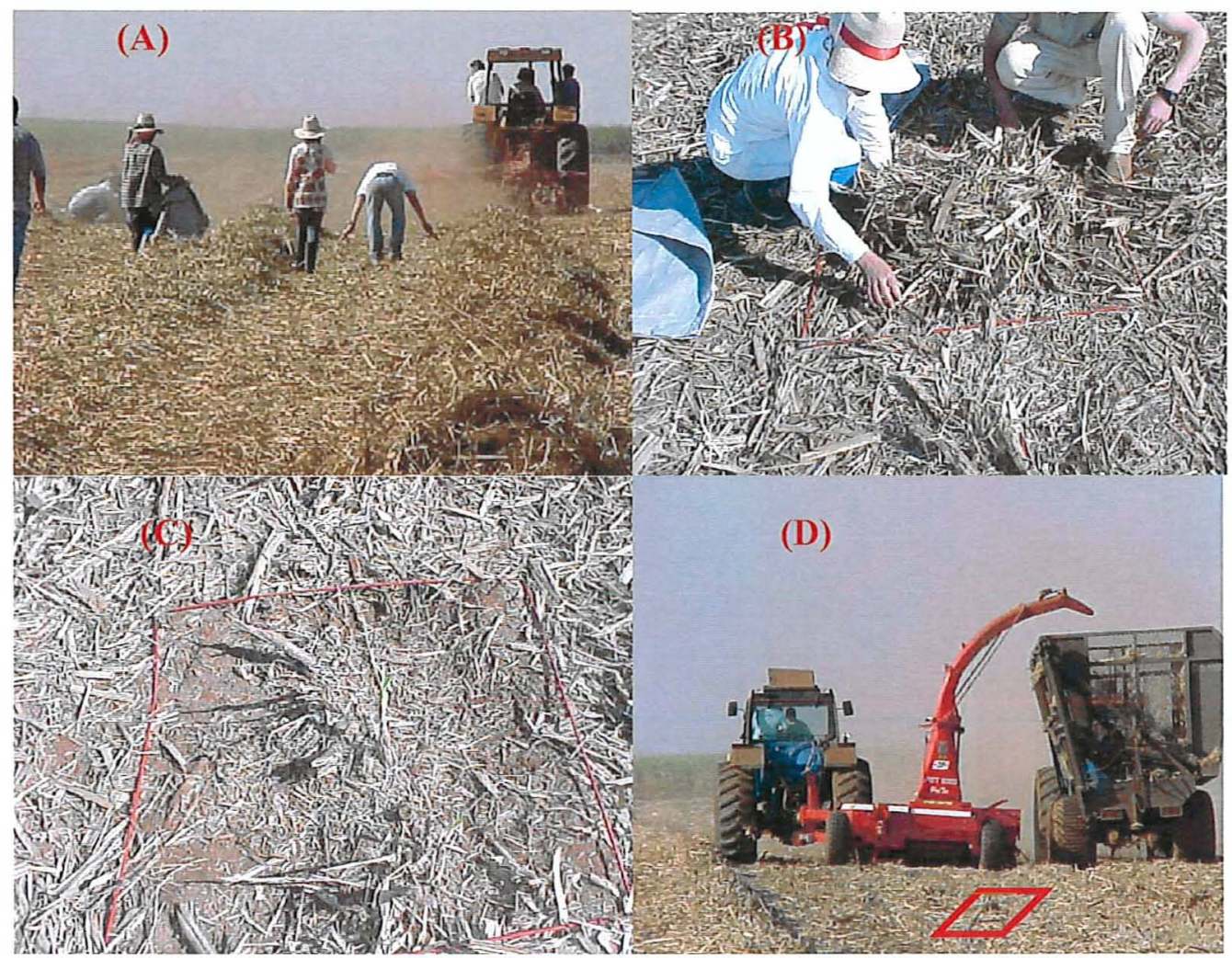

Figura 10- (A) Amostragem de palhiço remanescente sobre a área e após ação do ancinho; (B) Área de $1 \mathrm{~m}^{2}$, dentro do qual recolheu-se o material remanescente; (C) Área da amostra após recolhimento; (D) amostragens de palhiço remanescente sobre a área correspondente e após a ação da recolhedora

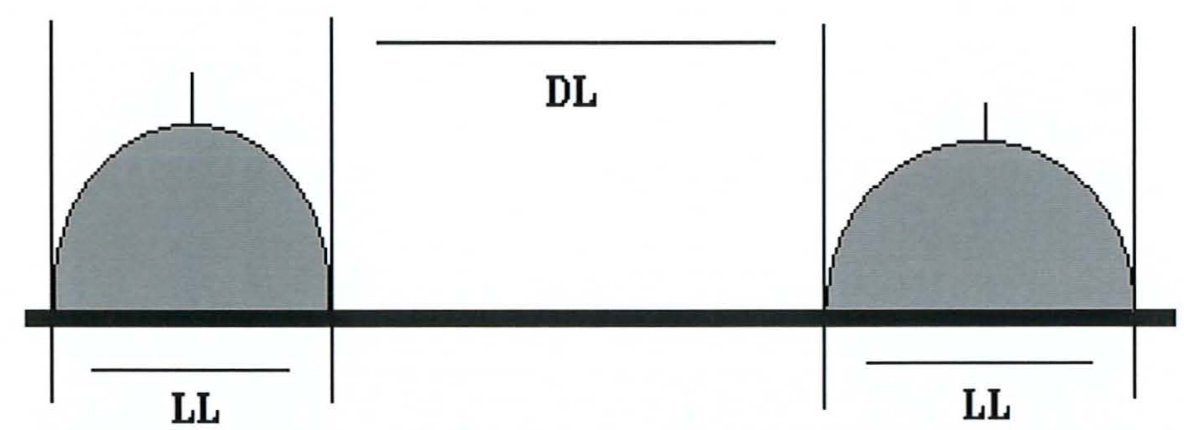

Figura 11- Critério para a determinação pelas operações, para obtenção, em ha, das perdas sendo, $\mathrm{DL}=$ distância entre leiras $(\mathrm{m})$ e $\mathrm{LL}=$ largura da leira $(\mathrm{m})$

Determinaram-se assim, as porcentagens de área coberta pelo ancinho e pela recolhedora, conforme as equações 28 e 29, respectivamente.

$$
\begin{aligned}
& (L L /(L L+D L)) \cdot 100 \\
& (D L /(L L+D L)) \cdot 100
\end{aligned}
$$




\subsubsection{Umidade do palhiço recolhido e a de terra arrastada no material manipulado e carregado na unidade de transporte.}

Em cada repetição da operação de recolhimento, que correspondeu a duas cargas do transbordo, foram obtidas duas amostras (Figura 12A), por carga, em dois caminhões de transporte específicos para carga à granel, com aberturas laterais nas carrocerias, num total de 32 amostras para as 8 repetições. O material amostrado foi analisado, pelo laboratório de PCTS na COSAN-Costa Pinto, para a obtenção da umidade e da porcentagem de terra existente no material.

O transporte do palhiço do local de estudo até o depósito de bagaço da usina foi realizado por caminhão de carroceria fechada (Figuras 12B e 12C) e, sua carga líquida correspondeu a cada duas repetições da operação de recolhimento.

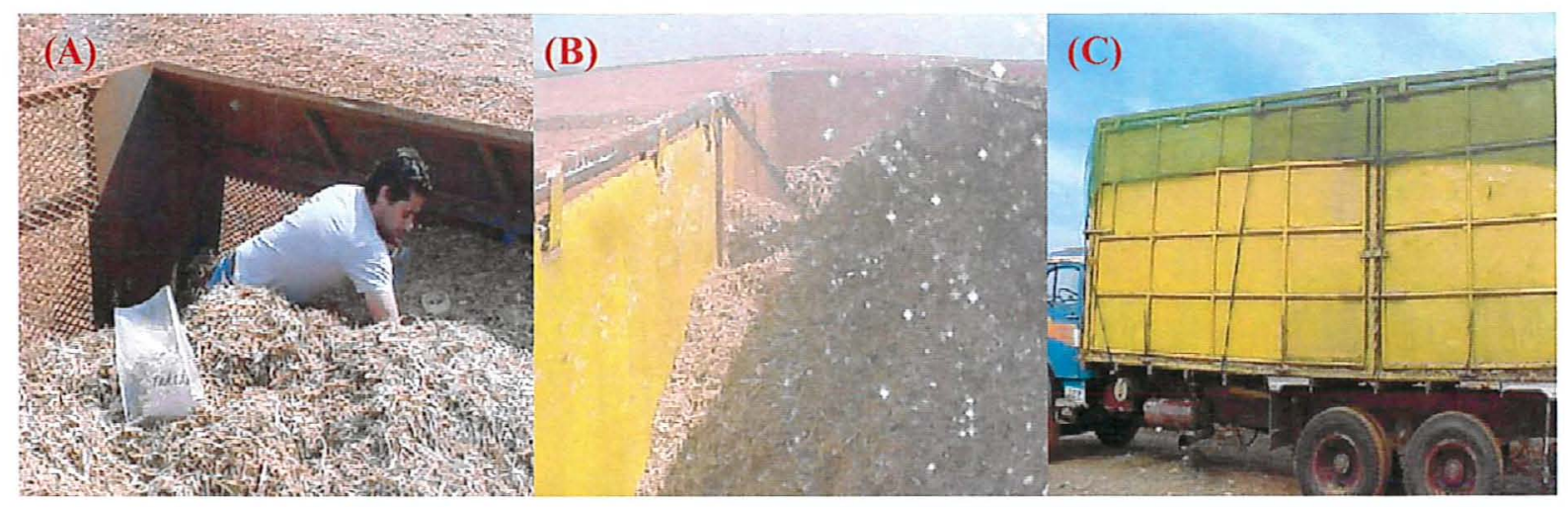

Figura 12- (A) Uma amostragem do palhiço colhido e carregado no transbordo; (B) palhiço transferido para o transporte; (C) transporte coberto com tela de nylon, para deslocamento

No depósito de bagaço da usina, foram cronometrados os tempos envolvidos para o descarregamento do material (Figuras 13A, 13B e 13C).

Mediram-se as dimensões das carrocerias, para a determinação do volume teórico de carga. Associando-se com a massa líquida de palhiço, obtida na balança de plataforma da usina, determinou-se a densidade de carga para cada tratamento. 


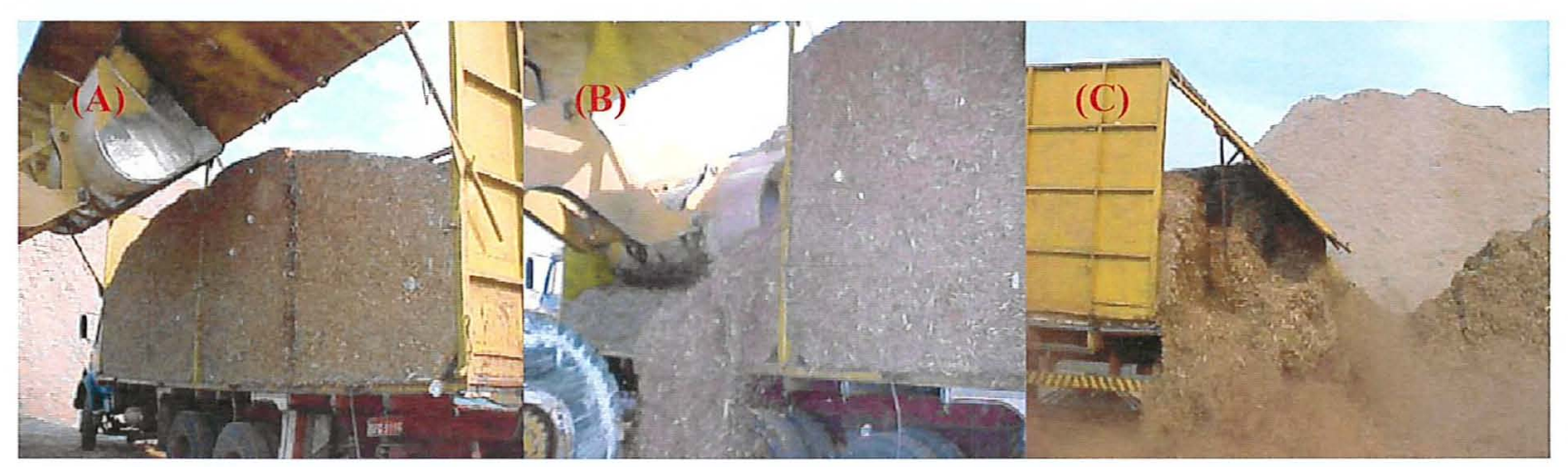

Figura 13- (A) Abertura das laterais, por meio de pá carregadora; (B) descarregamento do palhiço; (C) deposição do palhiço sobre o local

\subsubsection{Balanço enegético do sistema.}

Em cada tratamento estudado, determinou-se o seu balanço (eficiência) energético, ou seja, qual foi a relação entre a energia consumida, na forma de combustivel, nas diversas operações mecanizadas e de transporte. Determinou-se também a energia disponibilizada, na forma de palhiço, colocado na usina, utilizando-se a equação 30 .

$$
E L D=\left[1-\left(E C C / E C P_{1}\right)\right] \cdot 100
$$

Sendo:

ELD $(\%)=$ Energia líquida disponível, em percentagem .

ECC $\left(\mathrm{kcal}_{\mathrm{Kg}} \mathrm{K}^{-1}\right)=$ Energia consumida, na forma de óleo diesel.

$\mathrm{ECP}_{1}\left(\mathrm{kcal} . \mathrm{Kg}^{-1}\right)=$ Energia existente no palhiço.

Para cada uma das operações realizadas a determinação do balanço energético ocorrido, obedeceu ao seguinte método:

Adotando-se os valores obtidos por Ripoli (1991a), em relação aos poderes caloríficos superiores (PCS), encontrados nos constituintes do palhiço de cana-deaçúcar, conforme a Tabela 12.

Esta unidade de poder calorífico é determinada, para biomassa, com base em seu peso seco, através de procedimento laboratorial. Por sua vez, os poderes caloríficos Inferior (PCI) e Útil (PCU), são obtidos, partindo-se do valor PCS, aplicado às equações (1) e (2), desenvolvidas por Doat (1977), que levam em conta o grau de umidade desta biomassa e o seu teor de hidrogênio respectivamente. Em termos práticos, o que interessa, para a utilização de determinada biomassa, para fins 


\subsubsection{Análise Estatística}

O modelo estatístico aplicado para a obtenção dos dados de campo foi o inteiramente casualizado, utilizando-se do programa SAS.

As principais variáveis obtidas a partir dos dados originais de campo que passaram por análise estatística foram:

$\operatorname{BETS}(\%)$ = balanço (eficiência) energético do sistema.

$\operatorname{CDP}\left(\mathrm{R} \$ \mathrm{t}^{-1}\right)=$ custo do descarregamento do palhiço, a granel, na usina.

$\operatorname{CEP}\left(R \$ \mathrm{t}^{-1}\right)=$ custo do enleiramento do palhiço.

$\operatorname{CEPU}\left(\mathrm{R} \$ . \mathrm{EBP}^{-1}\right)=$ custo da energia contida no palhiço, posto na usina.

$\mathrm{CPPU}\left(\mathrm{R} \$ \mathrm{t}^{-1}\right)=$ custo total do palhiço, a granel, posto na usina.

$\operatorname{CRP}\left(R \$ \mathrm{t}^{-1}\right)=$ custo da operação de recolhimento do palhiço.

$\operatorname{CTP}\left(R \$ . t^{-1}\right)=$ custo do transporte do palhiço, a granel.

CTUT $\left(\right.$ EBP. $\left.t^{-1}\right)=$ consumo total de energia, na forma de combustivel, nas operações envolvidas no sistema (enleiramento + recolhimento + transporte + descarga).

$E \mathrm{CP}_{2}\left(\mathrm{EBP} . \mathrm{t}^{-1}\right)=$ quantidade de energia, em equivalente barril de petróleo, existente no palhiço descarregado na usina.

UPNT $(\%)=$ umidade do palhiço, no transporte.

$\operatorname{TPNT}(\%)=$ indice de terra contida no palhiço, posto na usina. 


\subsection{Resultados}

\subsubsection{O palhiço "in natura"}

Das amostras coletadas de palhiço "in natura" obteve-se para o tratamento T1 (com o enleirador JF) um percentual médio de $16,64 \%$ de umidade e $2,95 \%$ de terra. Para o tratamento T2 (com o enleirador DMB) obteve-se um percentual médio de 20,45 $\%$ de umidade e $2,27 \%$ de terra (Tabela 13).

A Tabela 13 apresenta a caracterização do palhiço "in natura", antes das operações de enleiramento e recolhimento para os resultados de umidade (UPin) e de terra (TPin).

Tabela 13- Caracterização do palhiço "in natura"

\begin{tabular}{ccc}
\hline & UPin & TPin \\
\hline TRATAMENTO & UMIDADE & TERRA \\
& $(\%)$ & $(\%)$ \\
\hline T1A1 & 11,54 & 2,87 \\
A2 & 12,88 & 3,68 \\
A3 & 11,80 & 4,03 \\
A4 & 8,78 & 4,63 \\
A5 & 15,52 & 2,12 \\
A6 & 39,30 & 0,34 \\
MÉDIAS & 16,64 & 2,95 \\
DP & 11,31 & 1,55 \\
CV & 68,01 & 52,67 \\
\hline & & \\
T2A1 & 20,66 & 4,00 \\
A2 & 37,04 & 2,02 \\
A3 & 32,04 & 2,77 \\
A4 & 13,12 & 1,36 \\
A5 & 8,68 & 0,81 \\
A6 & 11,16 & 2,67 \\
MÉDIAS & 20,45 & 2,27 \\
DP & 11,73 & 1,13 \\
CV & 57,37 & 49,90 \\
\hline
\end{tabular}


Quanto a quantidade de palhiço "in natura" existente na área estudada, pelas amostragens realizadas, constatou-se que, em média, a área continha uma massa total de palhiço de 14,1 t.ha ${ }^{-1}$ conforme mostra a Tabela 6 dos apêndices.

Utilizando-se dos dados obtidos em campo (conforme mostra a Tabela 6 dos apêndices) obteve-se a quantidade de palhiço "in natura" média na área de estudo dos tratamentos (T1 e T2), a qual totalizou 14,1 tha ${ }^{-1}$. A comparação entre o valor da produtividade média do palhiço com informações obtidas por outros autores confirma elevada variabilidade com relação a esta variável, devido a desigualdade de condições encontradas em cada um dos estudos, seja em função da umidade do palhiço, variedade e idade do canavial, entre outros, como ilustra a Figura 14.

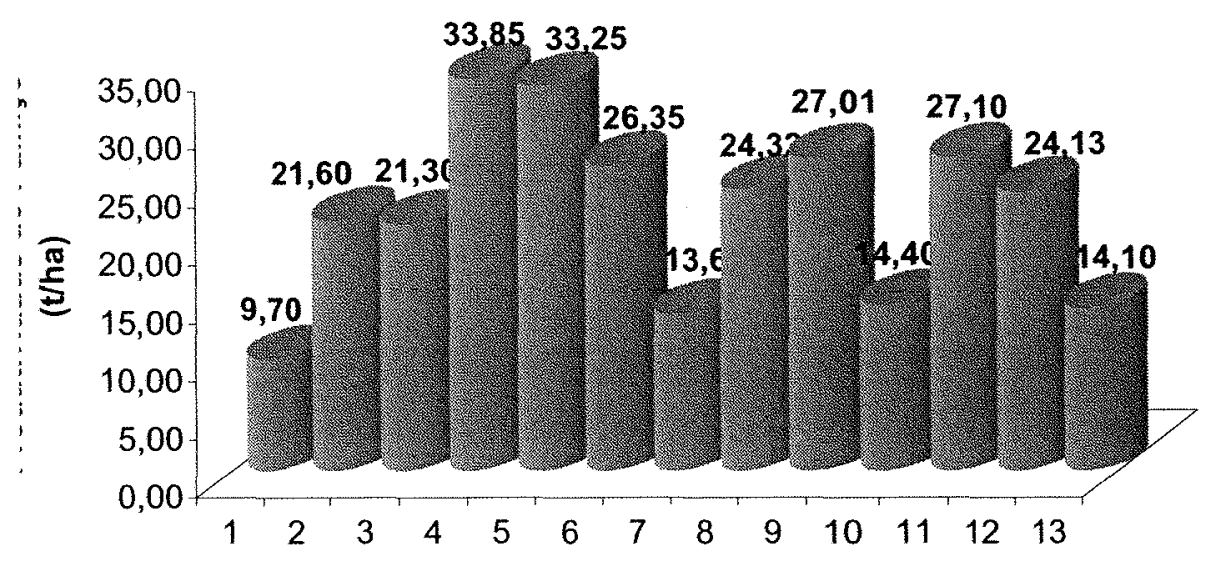

(1) Ripoli et al. (1990)

(2) Ripoli et al. (1991)

(3) Abramo Filho et al. (1993)

(4) Molina Jr et al. (1995)

(5) Ripoli et al. (1995a)

(6) Ripoli et al. (1995b)

(7) Furlani Neto et al. (1996)

(8) Furlani Neto et al. (1997)

(9) Bizuti (2003)

(10) Sartori (2001)

(11) Torresan (2003)

(12) Franco (2003)

(13) Neste estuito

Figura 14- Produtividade do palhiço "in natura", comparação obtida entre diversos autores

\subsubsection{Enleiramento}

Para a operação de enleiramento, comparando-se as médias das repetições nos tratamentos $(T 1=\mathrm{JF}$ e $\mathrm{T} 2=\mathrm{DMB})$ para a massa de palhiço enleirada (MPE) observou-se que T1 enleirou em média 9,70 t.ha $^{-1}$ e T2 enleirou em média 12,90 t.ha ${ }^{-1}$, sendo que T1 obteve uma velocidade efetiva média de $6,69 \mathrm{Km} \cdot \mathrm{h}^{-1}$ enquanto T2 apresentou 6,52 $\mathrm{Km} \cdot \mathrm{h}^{-1}$ e, a capacidade efetiva média de enleiramento de $\mathrm{T} 1$ foi de $6,87 \mathrm{t}$.ha ${ }^{-1}$ enquanto T2 ficou em 10,06 t.ha ${ }^{-1}$ conforme Tabela 14. 
Tabela 14- Operação de enleiramento, resultados de: velocidade de deslocamento, capacidades efetiva e operacional, consumo de combustível e massa de palhiço enleirado

\begin{tabular}{ccccccc}
\hline DESEMPENHO OPERACIONAL ENLEIRAMENTO & & & \multicolumn{2}{c}{ T1=JF } & \multicolumn{2}{c}{ T2=DMB } \\
\hline TRAT. & $\begin{array}{c}\text { VEE } \\
\left(\mathrm{km} \cdot \mathrm{h}^{-1}\right)\end{array}$ & $\begin{array}{c}\text { VOE } \\
\left(\mathrm{km} \cdot \mathrm{h}^{-1}\right)\end{array}$ & $\begin{array}{c}\text { CEE } \\
\left(\mathrm{t} \cdot \mathrm{h}^{-1}\right)\end{array}$ & $\begin{array}{c}\text { CEE } \\
\left(\mathrm{t} . \mathrm{ha}^{-1}\right)\end{array}$ & $\begin{array}{c}\text { COE } \\
\left(\mathrm{t} . \mathrm{h}^{-1}\right)\end{array}$ & $\begin{array}{c}\text { MPE } \\
\left(\mathrm{t} \cdot \mathrm{ha}^{-1}\right)\end{array}$ \\
\hline T1R1 & 6,51 & 5,54 & 5,18 & 6,34 & 4,69 & 8,12 \\
R2 & 6,53 & 5,88 & 7,38 & 6,57 & 6,24 & 10,06 \\
R3 & 6,47 & 5,82 & 8,69 & 7,59 & 7,37 & 10,67 \\
R4 & 6,39 & 5,83 & 8,09 & 7,65 & 6,93 & 11,05 \\
R5 & 6,44 & 5,87 & 8,19 & 7,39 & 6,96 & 9,66 \\
R6 & 6,46 & 5,84 & 6,97 & 6,15 & 5,78 & 8,87 \\
R7 & 7,36 & 6,64 & 6,97 & 6,23 & 5,34 & 8,86 \\
R8 & 7,36 & 6,62 & 8,02 & 7,05 & 6,30 & 10,31 \\
Médias & 6,69 & $\mathbf{6 , 0 0}$ & $\mathbf{7 , 4 4}$ & $\mathbf{6 , 8 7}$ & $\mathbf{6 , 2 0}$ & $\mathbf{9 , 7 0}$ \\
DP & 0,42 & 0,40 & 1,10 & 0,63 & 0,90 & 1,01 \\
CV & 6,23 & 6,66 & 14,76 & 9,10 & 14,51 & 10,43 \\
\hline T2R1 & 6,30 & 5,82 & 11,04 & 12,63 & 9,77 & 14,67 \\
R2 & 7,12 & 5,83 & 7,92 & 9,25 & 6,65 & 15,41 \\
R3 & 7,08 & 5,84 & 8,21 & 11,16 & 7,12 & 12,89 \\
R4 & 6,34 & 5,82 & 7,16 & 8,18 & 6,20 & 11,55 \\
R5 & 6,35 & 5,87 & 9,65 & 11,00 & 8,27 & 13,19 \\
R6 & 6,31 & 5,87 & 8,08 & 9,83 & 6,82 & 12,38 \\
R7 & 6,30 & 5,87 & 7,19 & 8,32 & 6,15 & 10,61 \\
R8 & 6,33 & 5,88 & 7,66 & 10,16 & 6,59 & 12,49 \\
Médias & $\mathbf{6 , 5 2}$ & $\mathbf{5 , 8 5}$ & $\mathbf{8 , 3 6}$ & $\mathbf{1 0 , 0 6}$ & $\mathbf{7 , 2 0}$ & $\mathbf{1 2 , 9 0}$ \\
DP & 0,36 & 0,03 & 1,33 & 1,51 & 1,23 & 1,56 \\
CV & 5,53 & 0,43 & 15,93 & 15,01 & 17,16 & 12,10 \\
\hline
\end{tabular}

Sendo: TRAT. $=$ Tratamentos; $V E E=$ velocidade média efetiva de enleiramento, $V O E=$ velocidade média operacional de enleiramento, $\mathrm{CEE}=$ capacidade efetiva média de enleiramento, $\mathrm{COE}=$ capacidade operacional média de enleiramento, MPE= massa de palhiço enleirado.

Dentre os principais fatores estudados a capacidade de campo efetiva constitui importante critério de comparação entre máquinas. Para comparação desta variável aqui obtida com outros autores (Tabela 15) foi necessária a utilização dos resultados médios obtidos nas capacidades de campo efetiva nos tratamentos T1 e T2 em ha. $h^{-1}$ mediante as Tabelas 3 e 4 dos apêndices.

Tabela 15- Análise entre máquinas enleiradoras, comparativo médio entre autores

\begin{tabular}{|c|c|c|c|}
\hline Neste estudo T1 e T2 ${ }^{(a)}$ & Torrezan $2003^{(b)}$ & Ripoli 1991a ${ }^{(c)}$ & Franco $2003^{(\mathrm{d})}$ \\
\hline $1,86^{(a)}$ & $2,45^{(b)}$ & $1,67^{(\mathrm{c})}$ & $5,34^{(d)}$ \\
\hline
\end{tabular}


Franco (2003), utilizou enleiradores John Deere 64 (T2) e DMB (T1) similar ao testado em T2 (DMB) neste estudo. Neste, obteve-se resultados superiores em função, principalmente, de maior velocidade $\left(\mathrm{Km}^{\mathrm{h}}{ }^{-1}\right)$ de operação, conforme Figura 15.

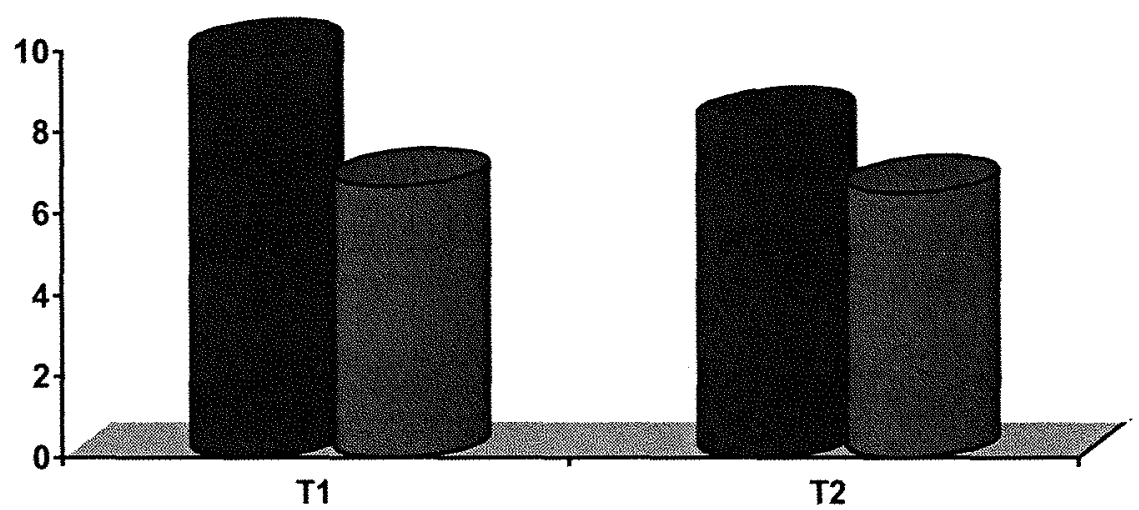

Franco, 2003

Neste estudo

Figura 15- Comparativo entre as velocidades médias $\left(\mathrm{Km} \cdot \mathrm{h}^{-1}\right)$ de enleiramento entre tratamentos para diferentes autores

\subsubsection{Recolhimento}

$\mathrm{Na}$ operação de recolhimento, comparando-se as médias das repetições nos dois tratamentos ( $T 1=\mathrm{JF}$ e $T 2=\mathrm{DMB}$ ) para a massa úmida com terra de palhiço recolhida, T1 obteve 7,1 t.ha ${ }^{-1}$ enquanto $T 2$ atingiu 10,7 t.ha $^{-1}$ conforme mostra a Tabela 6 dos apêndices.

Para a obtenção destes dados de recolhimento, em média, T1 operou à 2,99 $\mathrm{Km} . \mathrm{h}^{-1}$ de velocidade efetiva e obteve uma capacidade efetiva de $7,44 \mathrm{t} . \mathrm{h}^{-1} \mathrm{com}$ um palhiço de $16,64 \%$ de umidade e 3,14 \% de teor de terra agregado. Em T2 anotou-se um recolhimento à $2,85 \mathrm{Km} \cdot \mathrm{h}^{-1}$ de velocidade efetiva sendo que a capacidade efetiva ficou em 8,36 t.h h $^{-1}$ com um palhiço de $19,07 \%$ de umidade e 5,85 \% de teor de terra agregado conforme Tabela 16. 
Tabela 16- Operação de recolhimento, resultados de velocidade de deslocamento, capacidades efetiva e operacional, teor de umidade e terra contida no palhiço sobre o transporte

\begin{tabular}{ccccccc}
\hline TRAT. & $\begin{array}{c}\text { VER } \\
\left(\mathrm{km} . \mathrm{h}^{-1}\right)\end{array}$ & $\begin{array}{c}\text { VOR } \\
\left(\mathrm{km} \cdot \mathrm{h}^{-1}\right)\end{array}$ & $\begin{array}{c}\text { CER } \\
\left(\mathrm{t} . \mathrm{h}^{-1}\right)\end{array}$ & $\begin{array}{c}\text { COR } \\
\left(\mathrm{t} . \mathrm{h}^{-1}\right)\end{array}$ & $\begin{array}{c}\text { TPNT } \\
(\%)\end{array}$ & $\begin{array}{c}\text { UPNT } \\
(\%)\end{array}$ \\
\hline T1R1 & 2,29 & 2,07 & 5,18 & 4,69 & 2,04 & 19,63 \\
R2 & 3,11 & 2,63 & 7,38 & 6,24 & 3,20 & 19,63 \\
R3 & 3,20 & 2,72 & 8,69 & 7,37 & 2,04 & 20,71 \\
R4 & 2,87 & 2,46 & 8,09 & 6,93 & 4,96 & 16,53 \\
R5 & 3,08 & 2,62 & 8,19 & 6,96 & 2,92 & 16,95 \\
R6 & 3,11 & 2,58 & 6,97 & 5,78 & 3,96 & 10,90 \\
R7 & 3,08 & 2,37 & 6,97 & 5,34 & 3,52 & 14,48 \\
R8 & 3,17 & 2,49 & 8,02 & 6,30 & 2,45 & 14,33 \\
Médias & $\mathbf{2 , 9 9}$ & $\mathbf{2 , 4 9}$ & $\mathbf{7 , 4 4}$ & $\mathbf{6 , 2 0}$ & $\mathbf{3 , 1 4}$ & $\mathbf{1 6 , 6 4}$ \\
DP & $\mathbf{0 , 3 0}$ & $\mathbf{0 , 2 0}$ & $\mathbf{1 , 1 0}$ & $\mathbf{0 , 9 0}$ & 1,00 & $\mathbf{3 , 3 3}$ \\
CV & $\mathbf{1 0 , 0 4}$ & $\mathbf{8 , 1 2}$ & $\mathbf{1 4 , 7 6}$ & $\mathbf{1 4 , 5 1}$ & $\mathbf{3 2 , 0 2}$ & $\mathbf{1 9 , 9 9}$ \\
\hline T2R1 & 3,03 & 2,85 & 11,04 & 9,77 & 4,64 & 20,25 \\
R2 & 2,94 & 2,62 & 7,92 & 6,65 & 5,60 & 15,59 \\
R3 & 2,49 & 2,30 & 8,21 & 7,12 & 6,90 & 15,43 \\
R4 & 3,04 & 2,80 & 7,16 & 6,20 & 4,49 & 18,19 \\
R5 & 2,95 & 2,69 & 9,65 & 8,27 & 7,43 & 25,32 \\
\hline R6 & 2,86 & 2,56 & 8,08 & 6,82 & 4,28 & 21,40 \\
R7 & 2,90 & 2,64 & 7,19 & 6,15 & 7,67 & 17,48 \\
R8 & 2,58 & 2,36 & 7,66 & 6,59 & 5,79 & 18,89 \\
Médias & $\mathbf{2 , 8 5}$ & $\mathbf{2 , 6 0}$ & $\mathbf{8 , 3 6}$ & $\mathbf{7 , 2 0}$ & $\mathbf{5 , 8 5}$ & $\mathbf{1 9 , 0 7}$ \\
DP & $\mathbf{0 , 2 0}$ & $\mathbf{0 , 1 9}$ & $\mathbf{1 , 3 3}$ & $\mathbf{1 , 2 3}$ & $\mathbf{1 , 3 5}$ & $\mathbf{3 , 2 6}$ \\
CV & $\mathbf{7 , 1 7}$ & $\mathbf{7 , 4 6}$ & $\mathbf{1 5 , 9 3}$ & $\mathbf{1 7 , 1 6}$ & $\mathbf{2 3 , 0 8}$ & $\mathbf{1 7 , 1 1}$
\end{tabular}

Sendo: TRAT $=$ Tratamentos; $V E R=$ velocidade efetiva média de recolhimento; VOR= velocidade operacional média de recolhimento; $C E R=$ capacidade efetiva de recolhimento; $C O R=$ capacidade operacional de recolhimento; TPNT= percentagem de terra do palhiço, no transporte; UPNT= percentagem de umidade do palhiço, no transporte.

Um dos fatores determinantes neste estudo comparativo de máquinas, é a quantidade de palhiço recolhido e a sua capacidade de campo efetiva correspondente, conforme comparativo entre autores na Tabela 17.

Tabela 17- Comparativo entre autores na operação de recolhimento

Fontes Neste estudo

Franco 2003

Tratamentos T1

T2

T1

T2

$\begin{array}{ccccc}\text { PR }\left(\text { t.ha }{ }^{-1}\right) & 7,1 & 10,7 & 13,96 & 15,24 \\ \text { CCER }\left(\text { t. }{ }^{-1}\right) & 6,20 & 7,20 & 11,41 & 11,13\end{array}$

Sendo: $P R=$ Palhiço recolhido $\left(t . h a^{-1}\right) ;$ CCER $=$ Capacidade de campo efetiva de recolhimento $\left(t^{-1} h^{-1}\right)$. 
As massas de palhiço não recolhidas constituirão a camada protetora que ficará no solo de acordo com os métodos de plantio direto utilizados na área em estudo.

Outro fator de grande importância a ser analisado comparativamente é o teor de terra (\%) presente no palhiço recolhido, conforme Figura 16, por tratar-se de uma variável que acarreta problemas operacionais nas caldeiras.

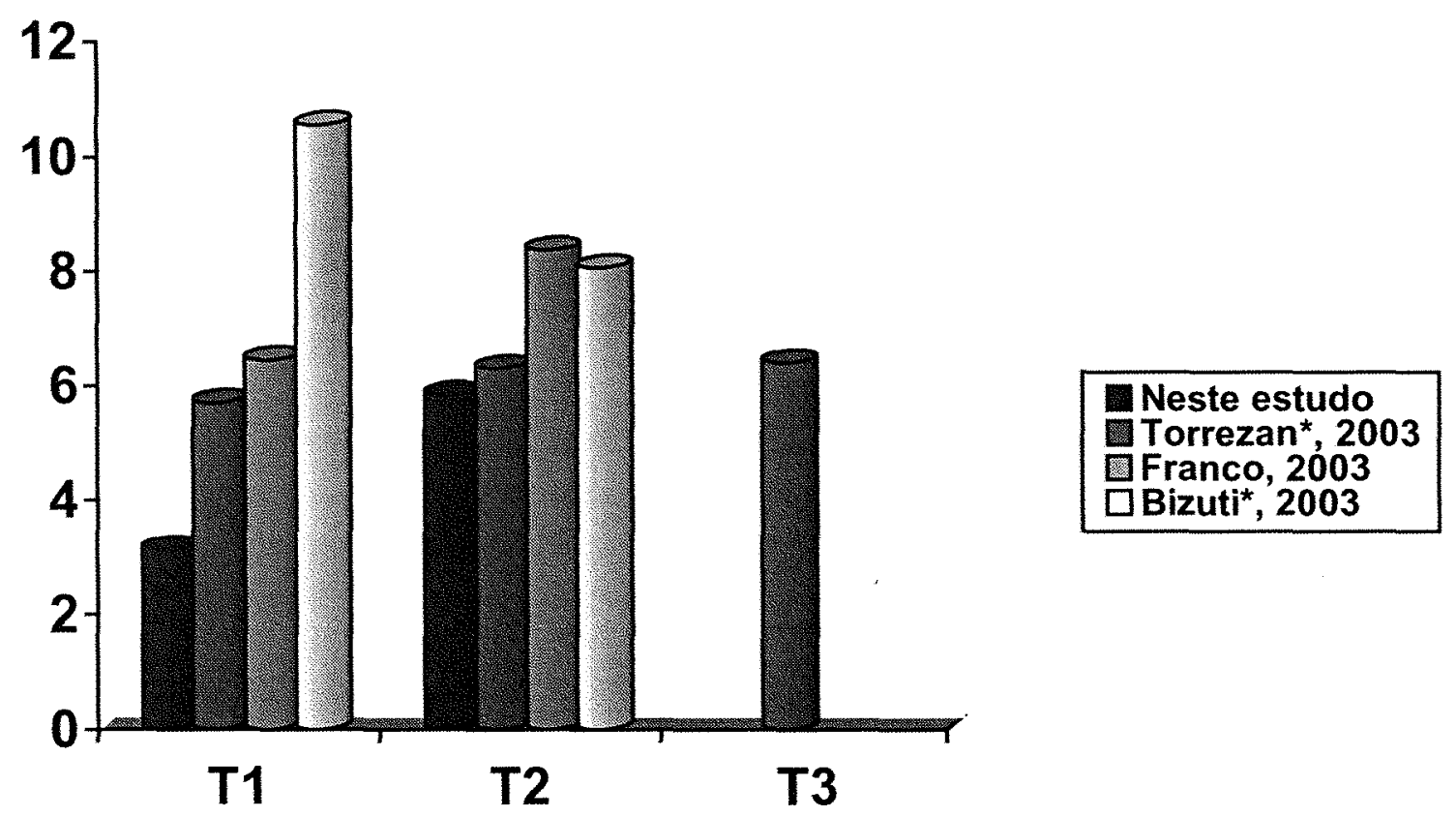

Figura 16- Comparativo entre o teor médio de terra (\%) presente no palhiço recolhido, entre tratamentos para diferentes autores ( ${ }^{*}$ autores que utilizaram o sistema de recolhimento por enfardamento)

Cabe ressaltar a dificuldade entre comparativos no quesito recolhimento por falta de estudos com o sistema a granel, a maioria dos dados apresentados dizem respeito a estudos de enfardamento de palhiço, o que dificulta uma comparação.

\subsubsection{Consumo de combustível}

Quanto ao consumo médio de combustível, comparando-se as médias das repetições (Tabela 18) nos dois tratamentos (T1=JF e T2=DMB) obteve-se em T1 um consumo na operação de enleiramento de $0,14 L^{-t^{-1}}$ e na operação de recolhimento 1,85 L.t $\mathrm{t}^{-1}$ enquanto que em T2 obteve-se na operação de enleiramento o consumo de 0,13 L.t $t^{-1}$ e na operação de recolhimento 1,79 L.t. $t^{-1}$. 
O consumo total médio das operações de enleiramento e recolhimento para T1 foi de 1,99 L. $\mathrm{t}^{-1}$ enquanto que T2 obteve 1,92 L.t $^{-1}$.

Tabela 18- Consumos de combustivel nas operações de enleiramento, recolhimento, transporte e descarga do palhiço na usina

\begin{tabular}{|c|c|c|c|c|c|c|c|c|c|}
\hline & TRAT. & $\begin{array}{l}\text { CONE } \\
\left(L . t^{-1}\right)\end{array}$ & $\begin{array}{c}\text { CONR } \\
\left(\text { L. }^{-1}\right)\end{array}$ & $\begin{array}{l}\text { CTRa } \\
\left({\left.\text { L. } . t^{-1}\right)}^{-1}\right.\end{array}$ & $\begin{array}{l}\text { CDES } \\
\left(\text { L. }^{-1}\right)\end{array}$ & $\begin{array}{l}\text { CTU } \\
\left(L . t^{-1}\right)\end{array}$ & $\begin{array}{c}\text { ECP } \\
\left(E B P, t^{-1}\right)\end{array}$ & $\begin{array}{c}\text { CTUT } \\
\left(\text { EBP. } t^{-1}\right)\end{array}$ & $\begin{array}{c}\text { BETS } \\
(\%)\end{array}$ \\
\hline \multirow[t]{11}{*}{$J F+J F$} & T1E1R1 & 0,200 & 3,100 & 1,110 & 0,960 & 5,360 & 1,650 & 0,043 & 97,390 \\
\hline & R2 & 0,150 & 1,440 & 1,170 & 0,960 & 3,720 & 1,530 & 0,029 & 98,050 \\
\hline & R3 & 0,100 & 1,230 & 0,940 & 0,960 & 3,230 & 1,510 & 0,025 & 98,290 \\
\hline & R4 & 0,110 & 1,760 & 0,980 & 0,960 & 3,810 & 1,590 & 0,030 & 98,080 \\
\hline & R5 & 0,150 & 1,720 & 1,170 & 0,960 & 4,000 & 1,590 & 0,032 & 97,970 \\
\hline & $\mathrm{R} 6$ & 0,160 & 1,910 & 0,990 & 0,960 & 4,020 & 1,700 & 0,032 & 98,110 \\
\hline & $\mathrm{R} 7$ & 0,120 & 1,760 & 1,040 & 0,960 & 3,880 & 1,630 & 0,031 & 98,090 \\
\hline & R8 & 0,100 & 1,850 & 1,170 & 0,960 & 4,080 & 1,640 & 0,032 & 98,000 \\
\hline & médias & 0,140 & 1,850 & 1,070 & 0,960 & 4,010 & 1,610 & 0,032 & 98,000 \\
\hline & DP & 0,030 & 0,550 & 0,100 & 0,000 & 0,610 & 0,060 & 0,005 & 0,260 \\
\hline & $\mathrm{CV}$ & 24,89 & 29,97 & 9,03 & 0,00 & 15,18 & 3,99 & 15,177 & 0,27 \\
\hline \multirow[t]{11}{*}{$\mathrm{DMB}+\mathrm{JF}$} & T1E2R1 & 0,09 & 1,67 & 1,02 & 0,96 & 3,74 & 1,52 & 0,0300 & 98,03 \\
\hline & $\mathrm{R} 2$ & 0,12 & 1,85 & 0,76 & 0,96 & 3,68 & 1,61 & 0,0295 & 98,17 \\
\hline & R3 & 0,14 & 1,81 & 1,16 & 0,96 & 4,07 & 1,56 & 0,0327 & 97,91 \\
\hline & $\mathrm{R} 4$ & 0,12 & 1,95 & 0,83 & 0,96 & 3,86 & 1,56 & 0,0310 & 98,02 \\
\hline & R5 & 0,10 & 1,64 & 0,99 & 0,96 & 3,70 & 1,42 & 0,0296 & 97,92 \\
\hline & $\mathrm{R} 6$ & 0,15 & 1,86 & 0,86 & 0,96 & 3,83 & 1,50 & 0,0307 & 97,95 \\
\hline & $\mathrm{R} 7$ & 0,18 & 1,78 & 0,94 & 0,96 & 3,85 & 1,57 & 0,0309 & 98,04 \\
\hline & R8 & 0,11 & 1,84 & 1,13 & 0,96 & 4,03 & 1,55 & 0,0324 & 97,91 \\
\hline & médias & 0,13 & 1,79 & 0,96 & 0,96 & 3,85 & 1,54 & 0,031 & 97,99 \\
\hline & DP & 0,03 & 1,36 & 0,14 & 0,00 & 0,15 & 0,06 & 0,001 & 0,09 \\
\hline & $\mathrm{CV}$ & 22,00 & 0,76 & 14,89 & 0,00 & 3,79 & 3,75 & 3,795 & 0,09 \\
\hline
\end{tabular}

Sendo: TRAT $=$ Tratamentos; $\quad$ CONE $=$ quantidade de combustivel consumida na operação de enleiramento; CONR= quantidade de combustivel consumida na operação de recolhimento; $\mathrm{CTRa}=$ quantidade de combustivel consumida no transporte; $\mathrm{CDEs}=$ quantidade de combustivel consumida no descarregamento; $\mathrm{CTU}=$ quantidade total de combustível consumida pelo sistema (enleiramento, recolhimento, transporte e descarga na usina); $\mathrm{ECP}=$ quantidade de energia, em equivalente barril de petróleo, existente no palhiço, posto na usina; CTUT= consumo total de energia, na forma de combustivel, nas operações envolvidas no sistema (enleiramento, recolhimento, transporte e descarregamento); $\mathrm{BETS}=$ balanço energético do sistema.

A validação comparativa entre resultados de bibliografia referente ao consumo de combustivel por operação e total em L.t ${ }^{-1}$ pode ser observado na Tabela 19, sendo que Torrezan (2003) e Bizuti (2003) avaliaram o sistema de recolhimento por enfardamento enquanto Franco (2003), apesar de avaliar o sistema de recolhimento a granel, utilizou uma recolhedora autopropelida. 
Tabela 19- Comparativo de consumo de combustivel entre autores

\begin{tabular}{cccccccccc}
\hline Autores & \multicolumn{2}{c}{$\begin{array}{c}\text { Neste } \\
\text { estudo }\end{array}$} & \multicolumn{2}{c}{ Torrezan } & \multicolumn{2}{c}{ Bizuti } & \multicolumn{2}{c}{ Franco } \\
Tratamentos & T1 & T2 & T1 $^{*}$ & T2 & T3* & T1 & T2 & T1 & T2 \\
\hline CCE & 0,14 & 0,13 & 0,18 & 0,21 & 0,24 & 0,18 & 0,20 & 0,03 & 0,05 \\
CCR & 1,85 & 1,79 & 1,37 & 1,49 & 1,40 & 0,64 & 0,43 & 3,34 & 3,29 \\
TOTAL & 1,99 & 1,92 & 1,55 & 1,70 & 1,64 & 0,82 & 0,63 & 3,37 & 3,34
\end{tabular}

Sendo: CCE = Consumo de combustível na operação de enleiramento em L.t ${ }^{-1}$; CCR = Consumo de combustivel na operação de recolhimento em L. $t^{-1}$; Total = Consumo total das operações (enleiramento + recolhimento) em L.t ${ }^{-1} ;{ }^{*}=$ Sistema de recolhimento por enfardamento.

\subsubsection{Custos}

Partindo-se dos valores fornecidos pela administração do GRUPO COSAN Unidade Costa Pinto, tabulados com os dados de campo obtidos, chegou-se aos resultados da Tabela 21 onde comparando-se as médias das repetições nos dois tratamentos $(T 1=J F$ e $T 2=D M B)$ para o total gasto para todas as operações (enleiramento + recolhimento + transporte + descarregamento) foi de 22,25 R\$. $\mathrm{t}^{-1} \mathrm{em}$ $\mathrm{T} 1$ e $20,74 \mathrm{R} \$ . \mathrm{t}^{-1} \mathrm{em} \mathrm{T} 2$.

Tabela 20- Desempenhos econômico das operações envolvidas no estudo

\begin{tabular}{|c|c|c|c|c|c|c|}
\hline & & CEP & CRP & CTP & CDP & CPPU \\
\hline$M A ́ Q$. & TRAT. & $\begin{array}{c}\mathrm{R} \$ \mathrm{t}^{-1} \\
\text { enleiramento }\end{array}$ & $\begin{array}{c}\mathrm{R} \$ \mathrm{t}^{-1} \\
\text { recolhimento }\end{array}$ & $\begin{array}{c}\mathrm{R} \$ \mathrm{t}^{-1} \\
\text { transporte }\end{array}$ & $\begin{array}{c}\mathrm{R} \$ \mathrm{t}^{-1} \\
\text { descarregamento }\end{array}$ & $\begin{array}{l}\mathrm{R} \$ \mathrm{t}^{-1} \\
\text { total }\end{array}$ \\
\hline \multirow[t]{11}{*}{$J F+J F$} & T1E1R1 & 1,53 & 10,32 & 8,90 & 2,51 & 23,26 \\
\hline & R2 & 1,47 & 9,95 & 8,90 & & \\
\hline & R3 & 1,28 & 8,62 & 8,90 & 2,11 & 20,90 \\
\hline & R4 & 1,26 & 8,55 & 8,90 & & \\
\hline & R5 & 1,31 & 8,86 & 8,90 & 2,37 & 21,44 \\
\hline & R6 & 1,57 & 10,64 & 8,90 & & \\
\hline & R7 & 1,55 & 10,50 & 8,90 & 2,43 & 23,39 \\
\hline & R8 & 1,37 & 9,28 & 8,90 & & \\
\hline & médias & 1,42 & 9,59 & 8,90 & 2,35 & 22,25 \\
\hline & DP & 0,13 & 0,87 & 0,00 & 0,18 & 1,26 \\
\hline & CV & 9,05 & 9,05 & 0,00 & 7,44 & 5,67 \\
\hline $\mathrm{DMB}+\mathrm{JF}$ & T1E2R1 & 0,94 & 7,17 & 8,90 & 1,95 & 18,96 \\
\hline & R2 & 1,28 & 9,79 & 8,90 & & \\
\hline & R3 & 1,06 & 8,12 & 8,90 & 2,19 & 20,27 \\
\hline & R4 & 1,45 & 11,07 & 8,90 & & \\
\hline & R5 & 1,08 & 8,23 & 8,90 & 2,03 & 20,24 \\
\hline
\end{tabular}


(conclusão)

\begin{tabular}{ccccccc}
\hline & & $\mathrm{CEP}$ & $\mathrm{CRP}$ & $\mathrm{CTP}$ & $\mathrm{CDP}$ & $\mathrm{CPPU}$ \\
\hline MÁQ. & TRAT. & $\begin{array}{c}\mathrm{R} \$ \mathrm{t}^{-1} \\
\text { enleiramento }\end{array}$ & $\begin{array}{c}\mathrm{R} \$ \mathrm{t}^{-1} \\
\text { recolhimento }\end{array}$ & $\begin{array}{c}\mathrm{R} \$ \mathrm{t}^{-1} \\
\text { transporte }\end{array}$ & $\begin{array}{c}\mathrm{R} \$ \mathrm{t}^{-1} \\
\text { descarregamento }\end{array}$ & $\begin{array}{c}\mathrm{R} \$ \mathrm{t}^{-1} \\
\text { total }\end{array}$ \\
\hline $\mathrm{R} 6$ & 1,21 & 9,21 & 8,90 & & \\
$\mathrm{R} 7$ & 1,43 & 10,89 & 8,90 & 2,27 & 23,49 \\
$\mathrm{R} 8$ & 1,17 & 8,91 & 8,90 & & \\
médias & $\mathbf{1 , 2 0}$ & $\mathbf{9 , 1 7}$ & $\mathbf{8 , 9 0}$ & $\mathbf{2 , 1 1}$ & $\mathbf{2 0 , 7 4}$ \\
$\mathrm{DP}$ & 0,18 & 1,36 & 0,00 & 0,15 & 1,93 \\
$\mathrm{CV}$ & 14,87 & 14,87 & 0,00 & 6,91 & 9,31 \\
\hline
\end{tabular}

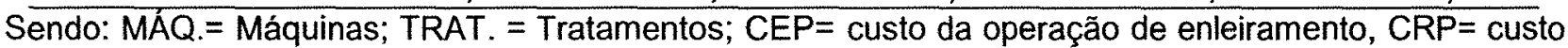
da operação de recolhimento, $\mathrm{CTP}=$ custo da operação de transporte, $\mathrm{CDP}=$ custo da operação de descarregamento, $\mathrm{CPPU}=$ custo total do palhiço posto na usina.

Pela Tabela 20, obtém-se a média entre os tratamentos para o custo total do palhiço posto na usina que, neste estudo, ficou em $\mathrm{R} \$ \mathrm{t}^{-1} 21,50$. Confrontado-se esse custo com os valores obtidos na bibliografia, para sistemas de recolhimento a granel do palhiço obtém-se a Figura 17.

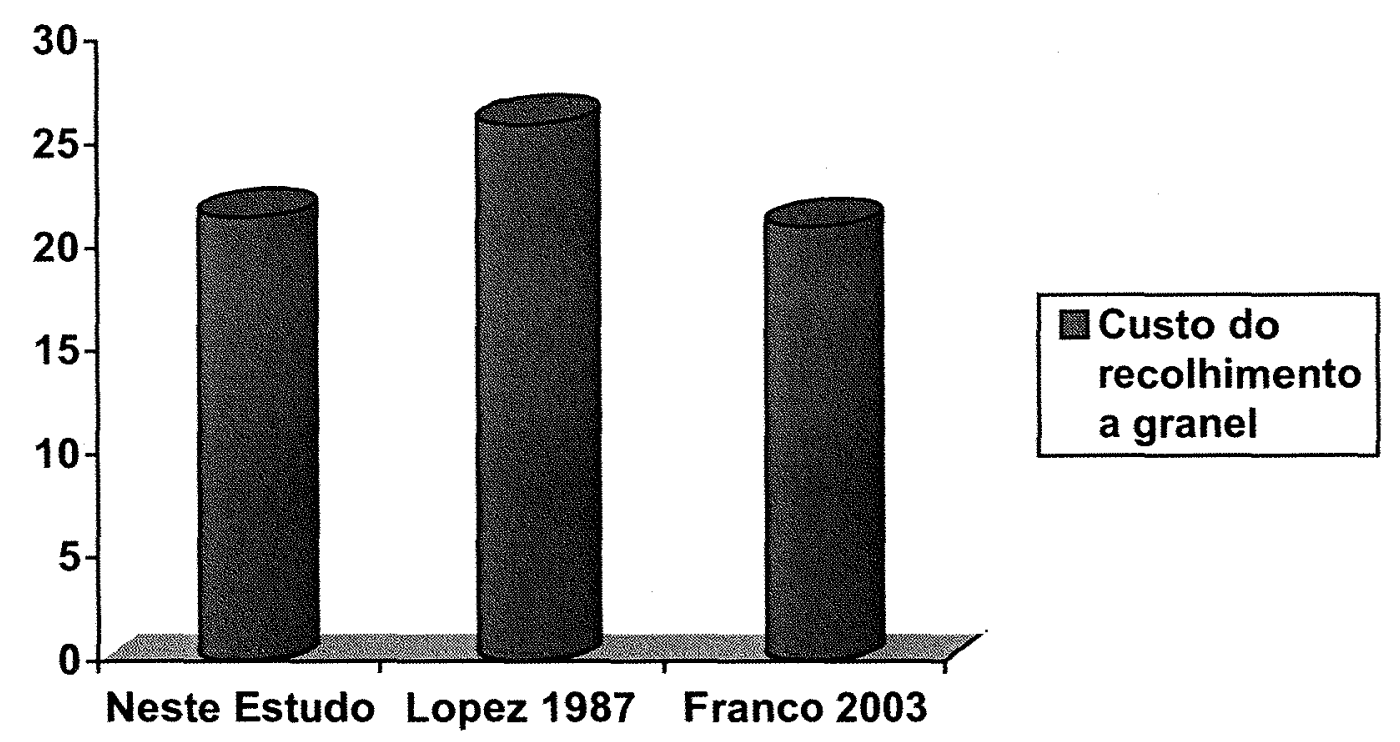

Figura 17- Validação comparativa entre autores para o custo do recolhimento a granel em $R \$ . t^{-1}$

Após todas as tabulações pertinentes foi possivel calcular o custo da energia, contida no palhiço, posto na usina onde, comparando-se as médias das repetições nos dois tratamentos ( $T 1=\mathrm{JF}$ e T2=DMB) observou-se que para $T 1$ foi de $R \$ . E B P^{-1} 13,94 \mathrm{e}$ T2 custa R\$.EBP ${ }^{-1} 13,65$, conforme Tabela 21. 
Tabela 21- Custo da energia, na forma de palhiço, colocada na usina

\begin{tabular}{|c|c|c|c|c|c|c|}
\hline$M A ́ Q$. & TRAT. & $\begin{array}{c}\text { BETS } \\
(\%)\end{array}$ & $\begin{array}{c}\text { CTUT } \\
\left(\text { EBP. } t^{-1}\right)\end{array}$ & $\begin{array}{c}E C P \\
\left(E B P \cdot t^{-1}\right)\end{array}$ & $\begin{array}{l}\text { CPPU } \\
\left(\mathrm{R} \$ \mathrm{t}^{-1}\right)\end{array}$ & $\begin{array}{c}\text { CEPU } \\
\left(\mathrm{R} \$ . \mathrm{EBP}^{-1}\right)\end{array}$ \\
\hline \multirow[t]{11}{*}{$\mathrm{JF}+\mathrm{JF}$} & T1E1R1 & 97,39 & 0,0430 & 1,65 & 23,26 & 14,09 \\
\hline & R2 & 98,05 & 0,0298 & 1,53 & & \\
\hline & R3 & 98,29 & 0,0259 & 1,51 & 20,90 & 13,82 \\
\hline & R4 & 98,08 & 0,0305 & 1,59 & & \\
\hline & R5 & 97,97 & 0,0321 & 1,59 & 21,44 & 13,53 \\
\hline & R6 & 98,11 & 0,0323 & 1,70 & & \\
\hline & R7 & 98,09 & 0,0312 & 1,63 & 23,39 & 14,32 \\
\hline & R8 & 98,00 & 0,0327 & 1,64 & & \\
\hline & médias & 98,00 & 0,03 & 1,61 & 22,25 & 13,94 \\
\hline & DP & 0,26 & 0,00 & 0,06 & 1,26 & 0,34 \\
\hline & CV & 0,27 & 15,18 & 3,99 & 5,67 & 2,45 \\
\hline \multirow[t]{11}{*}{$\mathrm{DMB}+\mathrm{JF}$} & T1E2R1 & 98,03 & 0,0300 & 1,52 & 18,96 & 12,47 \\
\hline & R2 & 98,17 & 0,0295 & 1,61 & & \\
\hline & R3 & 97,91 & 0,0327 & 1,56 & 20,27 & 12,98 \\
\hline & R4 & 98,02 & 0,0310 & 1,56 & & \\
\hline & R5 & 97,92 & 0,0296 & 1,42 & 20,24 & 14,23 \\
\hline & R6 & 97,95 & 0,0307 & 1,50 & & \\
\hline & R7 & 98,04 & 0,0309 & 1,57 & 23,49 & 14,91 \\
\hline & R8 & 97,91 & 0,0324 & 1,55 & & \\
\hline & médias & 97,99 & 0,03 & 1,54 & 20,74 & 13,65 \\
\hline & DP & 0,09 & 0,00 & 0,06 & 1,93 & 1,12 \\
\hline & CV & 0,09 & 3,79 & 3,75 & 9,31 & 8,22 \\
\hline
\end{tabular}

Sendo: $M A ́ Q .=$ Máquinas; $T R A T .=$ Tratamentos; $B E T S=$ balanço (eficiência) energética do sistema; CTUT= consumo total de energia, na forma de combustivel, nas operações envolvidas no sistema (enleiramento+recolhimento +descarga); $\mathrm{ECP}=$ quantidade de energia em equivalente barril de petróleo, existente no palhiço descarregado na usina; $\mathrm{CPPU}=$ custo total do palhiço descarregado na usina; $\mathrm{CEPU}=$ custo da energia, contida no palhiço, posto na usina.

Com base nos dados obtidos em campo em função da metodologia adotada, os custos básicos obtidos encontram-se na Tabela 22.

Tabela 22- Custos básicos obtidos

\begin{tabular}{cccc}
\hline Operações & Equipamentos & $\mathrm{R} \$ \mathrm{~h}^{-1}$ & $\mathrm{R} \$ \cdot \mathrm{ha}^{-1}$ \\
\hline Enleiramento & Ancinho DMB & 21,14 & 11,88 \\
& Ancinho JF & 22,66 & 9,68 \\
Recolhimento a granel & Recolhedora JF c/ DMB & 70,62 & 90,54 \\
& Recolhedora JF c/ JF & 68,68 & 65,41 \\
Transporte & Todos & $\sim$ & $\sim$ \\
Descarga & Todos & 60,00 & $\sim$ \\
\hline
\end{tabular}




\subsubsection{Resultados da análise estatística.}

Com base no relatório estatístico, apresenta-se na Tabela 23, o resumo dos resultados obtidos, nas variáveis analisadas. Médias com mesmas letras não diferiram significativamente.

Tabela 23- Resumo dos resultados obtidos na analise estatística das principais variáveis analisadas ao nível $5 \%$ de significância

$\operatorname{BETS}(\%)=$ balanço (eficiência) energético do sistema.

A

A

CTUT(EBP. . $\left.^{-1}\right)=$ consumo total de energia (combustivel) em todas as operações do sistema

A

A

ECP $\left(E B P . t^{-1}\right)=$ energia contida no palhiço posto na usina.

A

A

$\operatorname{CEP}\left(R \$ \mathrm{t}^{-1}\right)=$ custo da operação de enleiramento

A

B

$\mathrm{CRP}\left(\mathrm{R} \$ . \mathrm{t}^{-1}\right)=$ custo da operação de recolhimento A

A

$\mathrm{CTP}\left(R \$ . \mathrm{t}^{-1}\right)=$ custo da operação de transporte A

A

CPPU $\left(R \$ . t^{-1}\right)=$ custo total do palhiço posto na usina

A

A

CEPU $\left(R \$ . E B P^{-1}\right)=$ custo da energia, contida no palhiço, posto na usina

A

A

$\operatorname{CDP}\left(R \$ . t^{-1}\right)=$ custo da operação de descarregamento A

A
MÉDIAS

97,97

97,94

MÉDIAS

0,033

0,031

MÉDIAS

1,60

1,52

MÉDIAS

1,42

1,13

MÉDIAS

9,58

9,17

MÉDIAS

8,90

8,90

MÉDIAS

22,25

20,74

MÉDIAS

13,94

13,65

MÉDIAS

2,35

2,11 


\section{CONCLUSÕES}

Pode-se concluir que a utilização dos diferentes enleiradores não influenciou, de maneira significativa, as características do palhiço recolhido, nem o desempenho operacional da recolhedora, o que valida a hipótese de trabalho.

O objetivo deste estudo foi atingido pois, a presente avaliação comparativa mostrou-se válida em ensaios de campo, onde se obteve sua comprovação operacional e metodológica. Logo, tanto a metodologia adotada como o sistema de recolhimento a granel podem ser considerados como uma opção viável no gerenciamento do palhiço de cana-de-açúcar, deixado no campo no pós-colheita mecanizada, visando seu recolhimento e utilização na cogeração de energia elétrica.

Pelos resultados da análise estatística efetuadas com o teste de Tukey, pode-se concluir que, apenas a variável custo da operação de enleiramento (CEP), foi a que apresentou diferença mínima significativa (ao nível de $5 \%$ ), com vantagem para o ancinho fabricado pela DMB, porém não representou diferença significativa no custo da energia, na forma de palhiço, posta na usina (CEPU), quando comparado com o equipamento JF.

$O$ ancinho enleirador DMB apresentou melhores resultados referentes as capacidades de campo, em relação ao ancinho enleirador JF, no entanto, deve-se salientar sobre o maior teor de terra no palhiço recolhido nas leiras formadas pelo ancinho da DMB, que pode reduzir a vida útil das caldeiras.

$\mathrm{O}$ alto balanço energético do sistema, indica que todo o processo é econômica e tecnicamente viável. 


\section{REFERÊNCIAS}

ABRAMO FILHO, J.; MATSUOKA, S.; SPERANDIO,M.L.; RODRIGUES,R.C.D.; MARCHETTI, L.L. Resíduo da colheita mecanizada de cana crua. Álcool \& Açúcar, v.67, n.2, p.23-25, 1993.

AGÊNCIA NACIONAL DE ENERGIA ELÉTRICA (ANEEL), 2001.

http://www.aneel.gov.br, 2001.

BARTHOLOMEU, D.B.; SALVI, J.V.; ATALA JUNIOR., A.; ROCHA, M.T. In: Cogeração de energia a partir de bagaço de cana. Artigo aprovado para o XXXIX Congresso Brasileiro de Economia e Sociologia Rural (SOBER), fev. 2001.

BASSINELLO, A.I.; FURLANI NETO, V.L.; MACEDO, N.; PARRAZI, C; CASAGRANDE, J.C. Implicações agricolas e industriais da colheita da cana crua. Araras: IAA, PLANALSUCAR, s.d. 55p.

BIZUTI S.F.G. Enleiramento e enfardamento cilíndrico de palhiço de cana-deaçúcar: alguns parâmetros de desempenho operacional e eficiência energética. 2003 75p. Dissertação (Mestrado na área de máquinas agrícolas) - Escola Superior de Agricultura "Luiz de Queiroz", Universidade de São Paulo, Piracicaba, 2003.

BRITO, J.O; BARRICHELLO, L.E.G. Aspectos técnicos na utilização da madeira e carvão vegetal como combustíveis. In: SEMINÁRIO DE ABASTECIMENTO ENERGÉTICO INDUSTRIAL COM RECURSOS FLORESTAIS, 2, 1982, São Paulo. Anais. São Paulo: Secretaria de Ciência e Tecnologia, 1982. p.101-108.

CARIOCA, J.O.B.; AURORA, H.L. Biomassa: Fundamentos e aplicações tecnológicas, $1984,644 p$.

CASTRO, M. Usinas de açúcar e álcool vendendo energia elétrica. O Estado de São Paulo, 11 set. 1996. Suplemento agrícola, p.612-613

COELHO, S.T., A cogeração de eletricidade a partir de biomassa no setor industrial. www.ambiental.com.br/cenbio/biomassa/cogera.html, 24p., (20 maio 2001). 
COELHO, S.T.; ZYLBERSZTAJN, D. Barreiras e mecanismos de implementação a cogeração de eletricidade a partir da biomassa. DNA DA CANA-DE-AÇÚCAR, v.2, n.7, p.6-13, 1998.

COHEN, M. Uso de uma fonte renovável na matriz energética nacional. DNA DA CANA-DE-AÇÚCAR, v.5, n.1, p.8-12, 1998.

COMPANHIA PAULISTA DE FORÇA E LUZ, CPFL inova o setor energético com os contratos de cogeração. Usineiro, n.11, p.39-39, 1988.

CENTRO DE PREVISÃO DO TEMPO E ESTUDOS CLIMÁTICOS - INSTITUTO NACIONAL DE PESQUISAS ESPACIAIS (CPTEC - INPE), Energia Solar. www.cptec.inpe.br, 10 ago. 2003.

DELGADO, A.A. Os efeitos da queima dos canaviais. STAB, v.3, n.6, p.42-45, (jul/ago., 1985).

DNA DA CANA-DE-AÇÚCAR, Ribeirão Preto, v.5, n.7, p.15-19, 1998.

DOAT, A. Lê pouvoir calorifique dês bois tropical. Bois et Forets des Tropiques, Paris, v.172, p.33-42, mars/avr, 1977.

EID, F.; CHAN, K.; PINTO, S.S. Mudanças tecnológicas e cogeração de energia na industria sucroalcooleira. Revista de ciência e tecnologia política e gestão para a periferia, v.2, n.1, p.1-9, 1998.

ELETROBRÁS, Potência instalada (Mw) de cogeração do setor sucroalcooleiro. http://www.eletrobras.gov.br, 1999.

ETSU; HARWELL, Ficha 06: Energia da Biomassa. Rural - Europe. www.ruraleurope.aeidl.be/rural-pt/bibio/energy/fiche06.html, 4p., Reino Unido, (20 maio 2001).

FACCENDA, O. Cogeração de geração independente na industria sucroalcooleira, 1996, 140p. Tese (Doutorado em Agronomia / Energia na Agricultura) - Faculdade de Ciências Agronômicas, Universidade Estadual Paulista, "Julio de Mesquita Filho" Botucatu, 1996. 
FACCENDA, O.; SOUZA, L.G. A cogeração como alternativa no equacionamento da demanda de energia elétrica. Energia na agricultura. São Paulo, v.12, n.3, p.33-45, 1997.

FRANCO, F. N. Alguns parâmetros de desempenho operacional de um sistema de recolhimento de palhiço de cana-de-açúcar (Saccharum spp.) a granel, 2003. Dissertação (Mestrado na área de máquinas agrícolas) - Escola Superior de Agricultura "Luiz de Queiroz", Universidade de São Paulo. Piracicaba, 2003.

FURLANI NETO, V.L.; RIPOLI, T.C.C.; VILLA NOVA, N.A. Avaliação de desempenho operacional em canaviais com e sem queima prévia. STAB, Açúcar, Álcool e Subprodutos, v.15, n.2, p.18-23, nov./dez, 1996.

FURLANI NETO, V.L.; RIPOLI, T.C.C.; VILLA NOVA, N.A. Biomassa de cana-deaçúcar: Energia contida no palhiço remanescente de colheita mecânica. STAB, v.15, n.4, p.24-27, março/abril, 1997.

GUILHON, C.V. Bagaço de cana: substituto potencial do óleo combustivel. Brasil Açucareiro, v.99, n.1, p.17-21, 1982.

JORNAL CANA, Consumo de energia elétrica. Procana on line, 2000. http://www.jornalcana.com.br, 2000.

JORNAL de Piracicaba. A exploração em canaviais dos trabalhadores migrantes. Jornal de Piracicaba em (7/8/2003).

LOPES, O. O Palhiço. Brasil Açucareiro, Rio de Janeiro. v.75, n.1, p.64-67, jan. 1970.

LOPEZ, P.A. Recolección de barbojo como fuente energética em el Central romana. GRUPO DE PAÍSES LATINOAMERICANOS Y DEL CARIBE EXPORTADORES DE AZÚCAR. In: Uso alternativo de la caña de azúcar para energia y alimento. Ciudad del México, 1987. p. 57-62. (Coleccion GEPLACEA).

MIALHE, L. G. Máquinas motoras na agricultura. São Paulo: EPU; EDUSP, 1980. 2v. $364 p$. 
MOLINA JUNIOR, W.F.; RIPOLI, T.C.C.; GERALDI, R.N.; AMARAL, J.R. Aspectos econômicos e operacionais do enfardamento de resíduos de colheita de cana-deaçúcar para aproveitamento energético. STAB, Açúcar, Álcool e Subprodutos, v.13, n.5, p.28-31, mai./jun, 1995.

MME - Ministério de Minas e Energia. Produção de Eletricidade por Fonte de Energia, 1999. http://www.mme.gov.br

NEIVA, J. Fontes alternativas de energia, 2 ed. Rio de Janeiro: Maity, 1987, 155p.

PAYNE, J. H. Sugar and energy losses in burned cane. International Sugar Journal, Port Talbot, v. 88, n.1054, p. 191-192, oct. 1986.

POOLE, A.D. Bioenergy in Brazil - Biomass users network. Network News, v.7, n.2, p.1-4, 1993.

RIPOLI, T.C.C. Fogo na palha? Notícias da ESALQ, v.1., n.5, p.2-3, Piracicaba, nov., 1988.

RIPOLI, T.C.C. Utilização do material remanescente de colheita de cana-de-açúcar (Saccharum spp)- Equacionamento dos balanços energético e econômico. Piracicaba, 1991a. 150p (Livre Docência). Escola Superior de Agricultura "Luiz de Queiroz", Universidade de São Paulo.

RIPOLI, T.C.C. Ensaio \& certificação de máquinas para a colheita de cana-de-açúcar. In: MIALHE, L.G. Máquinas agrícolas: ensaios e certificação, Piracicaba: FEALQ, 1996. p.635-674.

RIPOLI, T. C.C. Algumas considerações sobre palhiço como fonte de energia (compact disc). In: SEMINÁRIO INTERNACIONAL CANA \& ENERGIA. 2001, Ribeirão Preto: Instituto Nacional de Eficiência Energética; Instituto de Desenvolvimento Agroindustrial, 2001.

RIPOLI, T.C.C.; PARANHOS, S.B. Cana-de-açúcar: Colheita Cana-de-açúcar: Cultivo e Utilização, 1, Campinas, Fundação Cargil v.2. cap. 5, p. 517-97, 1987. 
RIPOLI, T.C.C.; MOLINA JR., W. F. Cultura canavieira: um desperdício energético. Maquinaria Agrícola, v.6, n.1, p.2-3, jan. 1991b.

RIPOLI, T.C.C., VILLA NOVA, N.A. Colheita mecanizada da cana-de-açúcar. Novos Desafios. STAB, v.11, n.1, p.28-31, set / out. 1992.

RIPOLI, M.L.C.; RIPOLI, T.C.C. Caracterização dos principais constituintes da biomassa de cana-de-açúcar (Saccharum spp). In: SIMPÓSIO DE INICIAÇÃO CIENTÍFICA DA UNIVERSIDADE DE SÃO PAULO, 4., 1995b, São Paulo. Resumos. Piracicaba: Ed.EDUSP, 1995b. v.1, p.463.

RIPOLI, T.C.C.; RIPOLI, M.L.C. Energetic potencial of sugar cane biomass in Brazil. Rivista di Ingegneria Agraria, Bologna, v.31, n.1, feb., 2000.. p.2-7.

RIPOLI, T.C.C.; RIPOLI, M.L.C. Biomassa de cana-de-açúcar: colheita, energia e ambiente. Barros \& Marques Editioração Eletrônica. 302p. 1 ${ }^{\mathrm{a} E d}$. Piracicaba, 2004.

RIPOLI, T.C.C., MIALHE, L.G.; BRITO, J.O. Queima de canavial - o desperdício não mais admissivel! Álcool \& Açúcar, n. 54, p. 18-23. 1990b.

RIPOLI, T.C.C; TILLMAN, C.A. de C.; MILAN, M.O. O corte manual da cana verde. Álcool e Açúcar, v.77, p.28-30, 1995a.

RIPOLI, T.C.C.; MOLINA J.R., W.F.; NOGUEIRA. M.C.S.; MATOS DE, J.R. Potencial energético do palhiço da cana-de-açúcar. In: CONGRESSO BRASILEIRO DE ENGENHARIA AGRÍCOLA. Resumos. Piracicaba, FEALQ: SBEA, 1990a. p.26.

RIPOLI, T.C.C.; BALASTREIRE, L.A.; MOLIN, J.P.; MOLINA JUNIOR, W.F. Sugar cana biomass energy in Brazil. In: INTERNATIONAL CONGRESS ON AGRICULTURAL ENGINEERING, Morocco, 13, 1998. Anais. Morocco: ICAE, 1998. v.4, p.51-57.

RIPOLI, M.L.C.; RIPOLI, T.C.C.; GAMERO, C.A. Colheita integral: retrocesso ou barateamento do sistema? IDEA NEWS, v. 4, n. 28, p.66-67, jan./2003. 
ROSSI, I.H. Suplementação de bagaço de cana para cultivo axênico do cogumelo shiitake (Lentinula edodes (Berk.) Pegler). 1999. 129p. Dissertação (Mestrado em Microbiologia) - Faculdade de Ciências Agrárias e Veterinárias, Universidade Estadual Paulista. "Julio de Mesquita Filho". Jaboticabal, 1999.

SARTORI, M.M.P. Otimização da produção de energia e biomassa do resíduo de colheita em variedades de cana-de-açúcar. 2001. Tese (Doutorado) Faculdade de Ciências Agronômicas, Universidade Estadual Paulista "Julio de Mesquita Filho".

Botucatu, 2001.

SLEIMAN, E.M. Avaliação estatístico econômica do potencial para a produção de energia elétrica excedente a partir do bagaço em uma industria de processamento de cana-de-açúcar. 1998. 82p. Dissertação (Mestrado, Agronomia / Energia na Agricultura) - Faculdade de Ciências Agronômicas, Universidade Estadual Paulista. "Julio de Mesquita Filho". Botucatu, 1998.

SECRETARIA DE ESTADO DO MEIO AMBIENTE - SMA, São Paulo, 2003. http://www.ambiente.sp.gov.br

SECRETARIA DE ENERGIA DO ESTADO DE SÃO PAULO. Cogeração de energia. http://www.energia.sp.gov.br, 1997.

SOUZA, Z.J. Uma avaliação das formas de comercialização da energia cogerada pelo setor sucroalcooleiro. 1999. 116p. Dissertação (Mestrado em Economia Aplicada) - Escola Superior de Agricultura "Luiz de Queiroz", Universidade de São Paulo. Piracicaba, 1999.

STEEL, J.G.; BRADFIELD, R. The significance of size distribution in the clay fraction. In: AMERICAN SOIL SURVEY ASS. p.88-93. (Report Bulletin, 1934).

TORRESAN, H.F. Enleiramento e enfardamento prismático de palhiço de cana-deaçúcar: alguns parâmetros de desempenho operacional e eficiência energética. 2003. 88p. Dissertação (Mestrado na área de máquinas agrícolas), Escola Superior de Agricultura Luiz de Queiroz, Universidade de São Paulo. Piracicaba, 2003.

UNICA - União da agroindústria canavieira de São Paulo: Cana-de-açúcar; açúcar; álcool; pesquisa e desenvolvimento, legislação; estatísticas; artigos e publicações. http://www.unica.com.br; (jul. 2003). 
URQUIAGA, S.; RESENDE DA SILVA, A.; ALVES, B.J.R.; OLIVEIRA, O.C.; BODDEY, R.M. Queima da cana, EMBRAPA - Agrobiologia. http://www.cnpab.embrapa.br, 4p. 20 maio 2001.

WALTER, A.C.S. Potencial energético da cana-de-açúcar. STAB. Açúcar, Álcool e Subprodutos, v.11, n.4, p.29-34, mar. / abril, 1993.

ZULAUF, W.E.; CAPORALI, S.A.; VIDEIRA, R.M. Cálculo preliminar da energia liberada anualmente na queima dos canaviais brasileiros. In: SIMPÓSIO SOBRE QUEIMA DE PALHA DE CANAVIAIS, 2., p. 1-7. Araraquara, 1985. 
APÊNDICES 
Tabela 1 Análise granulométrica e teor de umidade do solo na área do estudo

\begin{tabular}{ccccc}
\hline amostra & $\begin{array}{c}\text { argila } \\
(\%)\end{array}$ & $\begin{array}{c}\text { silte } \\
(\%)\end{array}$ & $\begin{array}{c}\text { areia } \\
(\%)\end{array}$ & $\begin{array}{c}\text { umidade } \\
(\%)\end{array}$ \\
\hline a1 & 38,82 & 21,84 & 39,34 & 15,54 \\
a2 & 34,59 & 16,06 & 49,35 & 10,51 \\
a3 & 30,08 & 27,56 & 42,36 & 17,70 \\
a4 & 34,17 & 25,03 & 40,80 & 16,15 \\
a5 & 23,46 & 24,57 & 51,97 & 16,33 \\
a6 & 11,89 & 24,93 & 63,18 & 12,21 \\
medias & 28,84 & 23,33 & 47,83 & 14,74 \\
$D P$ & 9,79 & 4,00 & 9,02 & 2,76 \\
CV & 33,94 & 17,14 & 18,85 & 18,75 \\
\hline
\end{tabular}

Tabela 2. Determinação do teor de umidade e quantidade de terra nas amostras, contida no transbordo

TRATAMENTO: T1(JF+JF) e T2(DMB+JF)

(continua)

\begin{tabular}{lcc}
\hline TRAT & $\begin{array}{c}\text { Umidade } \% \\
\text { UPNT }\end{array}$ & Terra\% \\
REP & 13,32 & 2,26 \\
\hline T1R1A1 & 11,98 & 3,20 \\
A2 & 12,29 & 0,80 \\
A3 & 16,78 & 1,91 \\
A4 & 13,59 & 2,04 \\
media & 19,56 & 2,38 \\
R2A1 & 17,92 & 4,80 \\
A2 & 21,09 & 3,37 \\
A3 & 19,93 & 2,25 \\
A4 & 19,63 & 3,20 \\
MEDIA & 21,58 & 2,46 \\
R3A1 & 20,94 & 1,99 \\
A2 & 19,25 & 1,56 \\
A3 & 21,05 & 2,16 \\
A4 & 20,71 & 2,04 \\
MEDIA & 16,63 & 2,84 \\
R4A1 & 20,12 & 1,27 \\
A2 & 18,60 & 7,45 \\
A3 & 10,77 & 8,27 \\
A4 & 16,53 & 4,96
\end{tabular}


(continuação)

\begin{tabular}{lcc}
\hline TRAT & $\begin{array}{c}\text { Umidade } \% \\
\text { UPNT }\end{array}$ & Terra\% \\
REP & 22,87 & TPNT \\
\hline R5A1 & 14,53 & 0,00 \\
A2 & 13,65 & 3,30 \\
A3 & 16,75 & 3,25 \\
A4 & 16,95 & 5,11 \\
MEDIA & 7,80 & 2,92 \\
\hline R6A1 & 11,70 & 5,01 \\
A2 & 12,93 & 6,00 \\
A3 & 11,15 & 1,34 \\
A4 & 10,90 & 3,48 \\
MEDIA & 13,39 & 3,96 \\
\hline R7A1 & 13,52 & 4,18 \\
A2 & 11,75 & 2,97 \\
A3 & 19,24 & 1,88 \\
A4 & 14,48 & 5,05 \\
MEDIA & 13,49 & 3,52 \\
\hline R8A1 & 14,69 & 2,09 \\
A2 & 13,48 & 1,73 \\
A3 & 15,67 & 3,06 \\
A4 & 14,33 & 2,92 \\
MEDIA & 18,75 & 2,45 \\
\hline T2R1A1 & 19,1 & 5,34 \\
A2 & 20,51 & 4,47 \\
A3 & 22,62 & 3,44 \\
A4 & 20,25 & 5,3 \\
MEDIA & 16,60 & 4,64 \\
\hline R2A1 & 14,17 & 5,30 \\
A2 & 15,47 & 3,37 \\
A3 & 16,13 & 5,18 \\
A4 & 15,59 & 8,57 \\
MEDIA & 5,60 \\
\hline R3A1 & 15,85 & 5,80 \\
A2 & 14,60 & 10,35 \\
A3 & 15,98 & 5,36 \\
A4 & 15,29 & 6,08 \\
MEDIA & 15,43 & 6,90 \\
& & \\
\hline
\end{tabular}


(conclusão)

\begin{tabular}{|c|c|c|}
\hline TRAT & Umidade $\%$ & Terra\% \\
\hline REP & UPNT & TPNT \\
\hline $\mathrm{R} 4 \mathrm{~A} 1$ & 15,68 & 7,85 \\
\hline $\mathrm{A} 2$ & 18,65 & 2,83 \\
\hline A3 & 17,50 & 2,39 \\
\hline $\mathrm{A} 4$ & 20,91 & 4,88 \\
\hline MEDIA & 18,19 & 4,49 \\
\hline R5A1 & 21,56 & 11,56 \\
\hline $\mathrm{A} 2$ & 21,60 & 7,56 \\
\hline $\mathrm{A} 3$ & 29,61 & 5,15 \\
\hline A4 & 28,49 & 5,46 \\
\hline MEDIA & 25,32 & 7,43 \\
\hline $\mathrm{R} 6 \mathrm{~A} 1$ & 18,52 & 5,54 \\
\hline $\mathrm{A} 2$ & 23,77 & 1,27 \\
\hline A3 & 20,30 & 4,77 \\
\hline A4 & 22,99 & 5,53 \\
\hline MEDIA & 21,40 & 4,28 \\
\hline R7A1 & 16,84 & 5,15 \\
\hline $\mathrm{A} 2$ & 19,03 & 6,77 \\
\hline $\mathrm{A} 3$ & 16,40 & 7,13 \\
\hline A4 & 17,65 & 11,61 \\
\hline MEDIA & 17,48 & 7,67 \\
\hline R8A1 & 20,92 & 8,67 \\
\hline $\mathrm{A} 2$ & 20,40 & 5,88 \\
\hline A3 & 17,58 & 3,89 \\
\hline A4 & 16,67 & 4,73 \\
\hline MEDIA & 18,89 & 5,79 \\
\hline
\end{tabular}




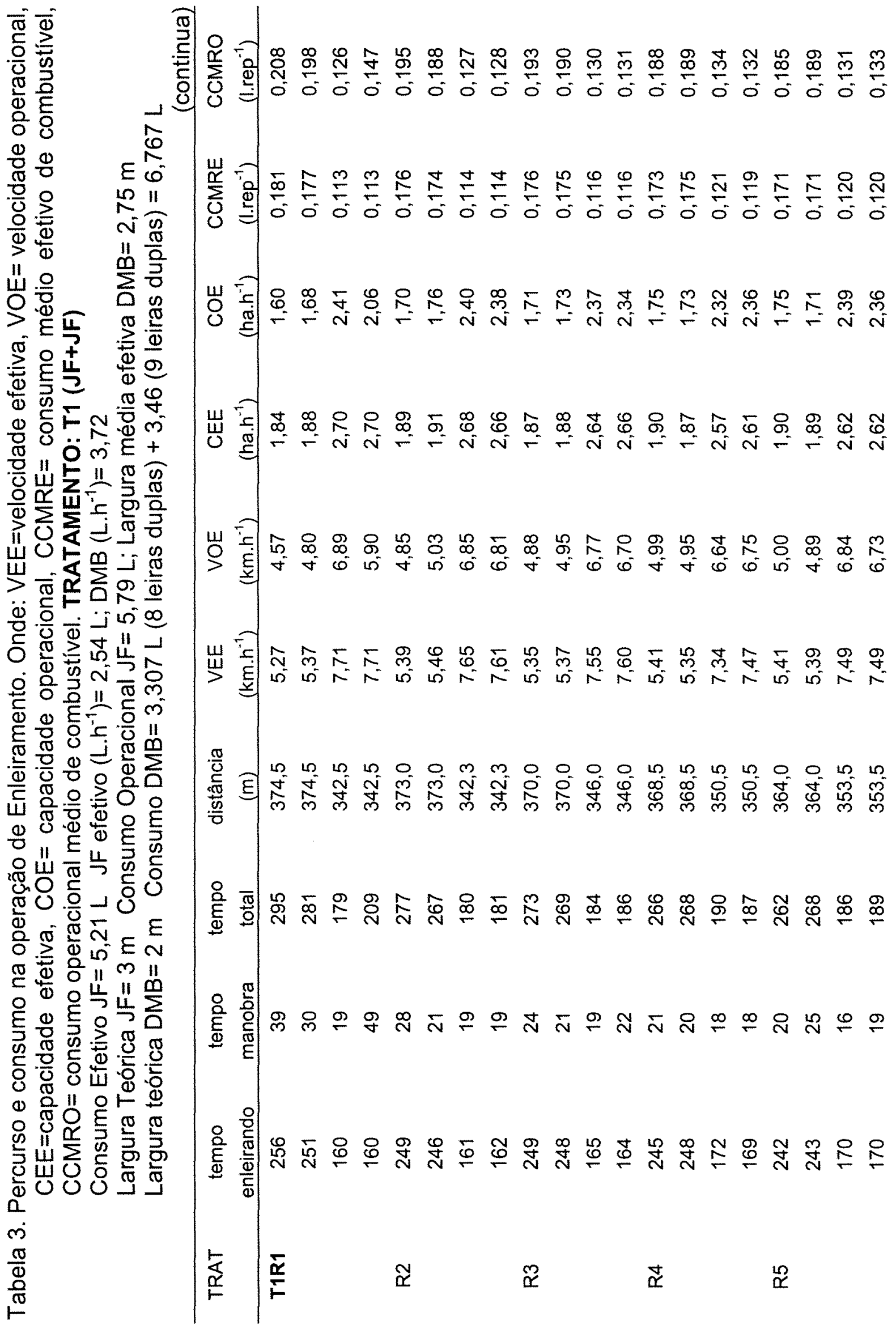




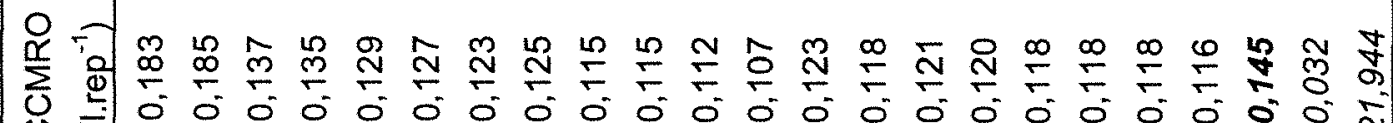
8

苻

山

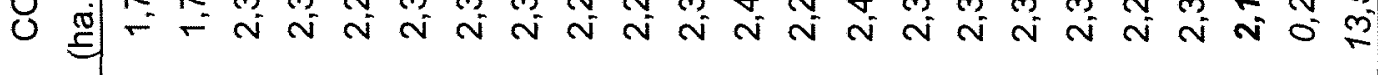

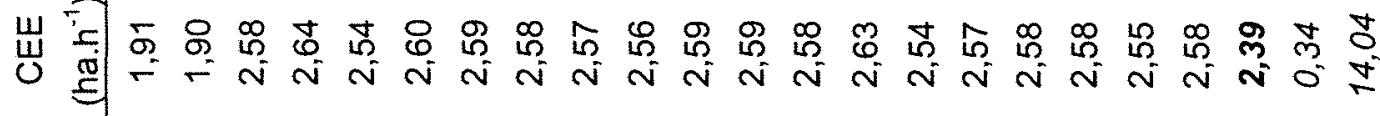

岁

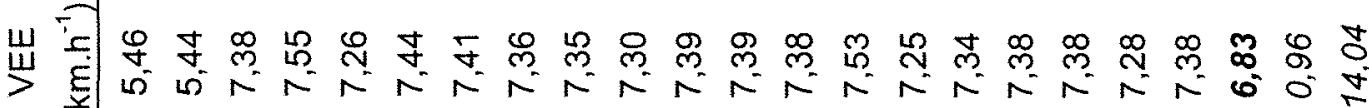
这 क

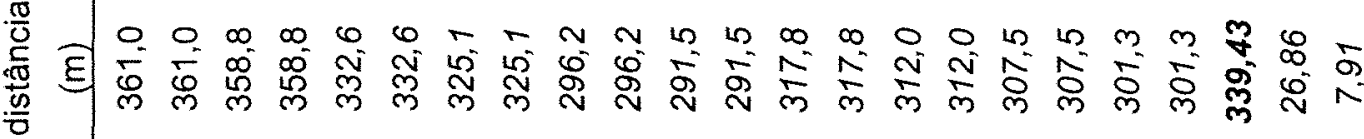

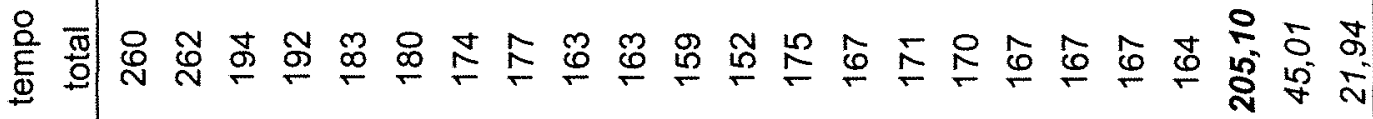

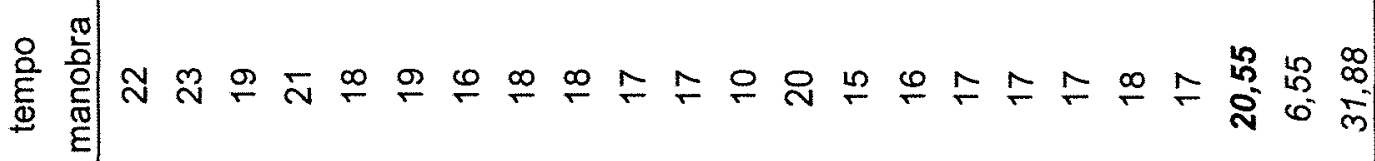

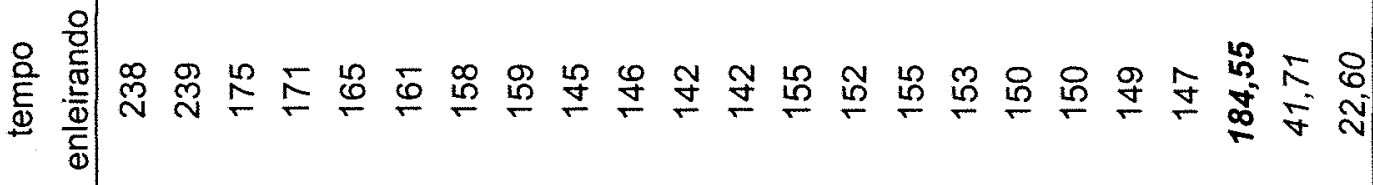

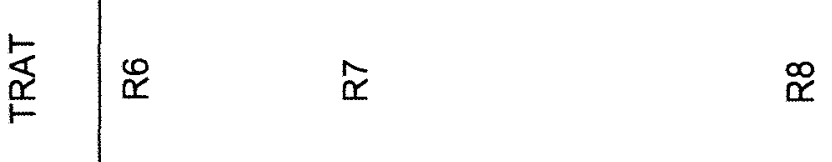

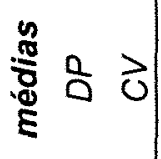




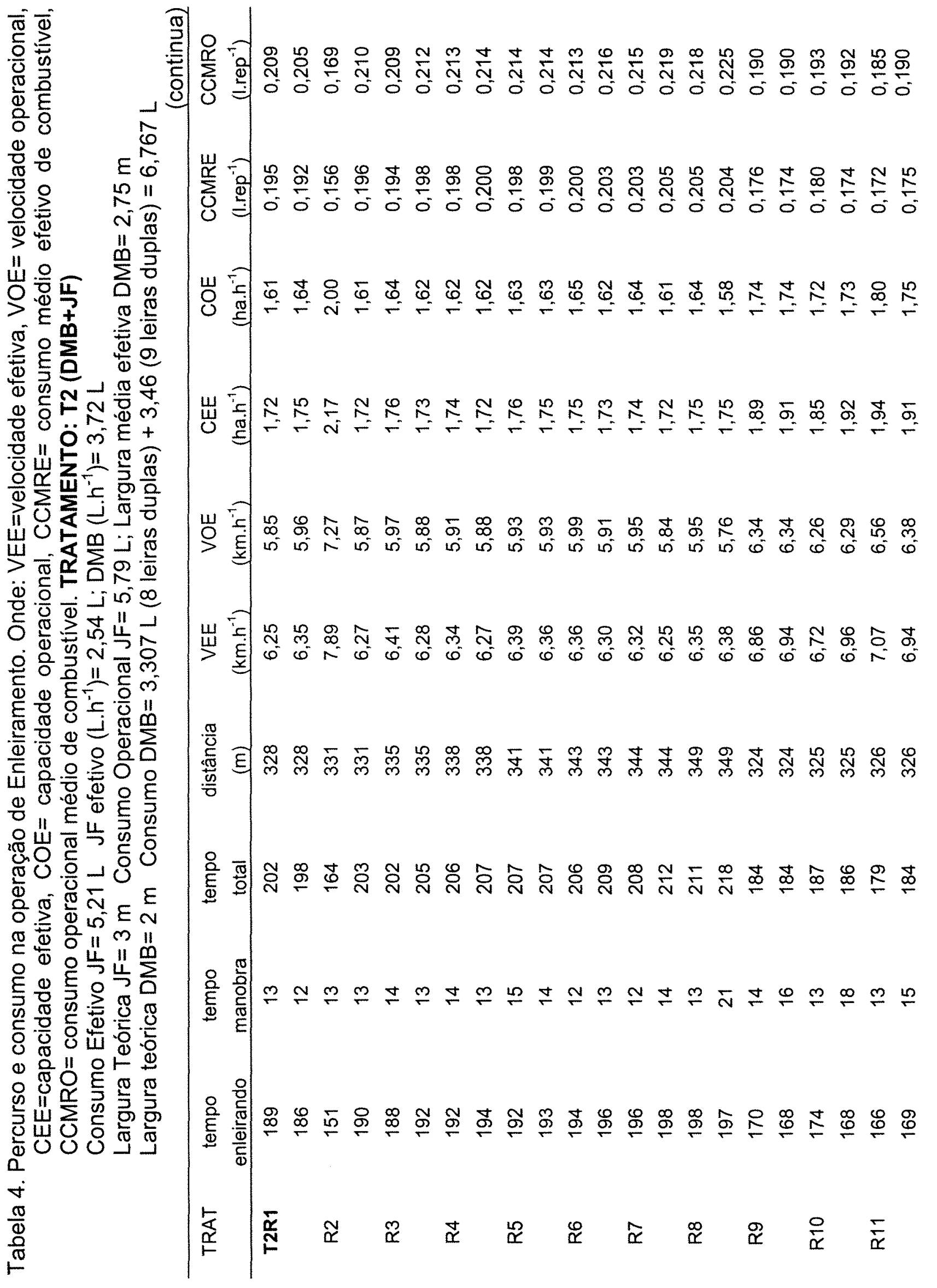




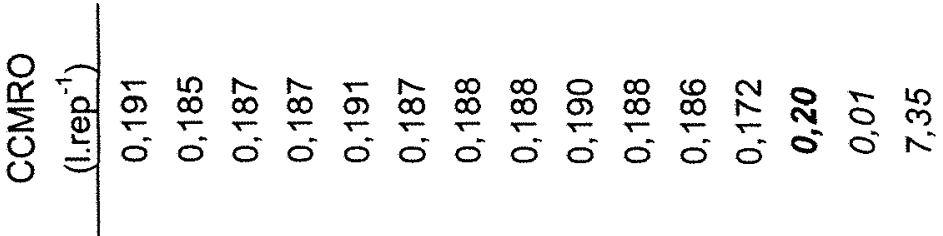

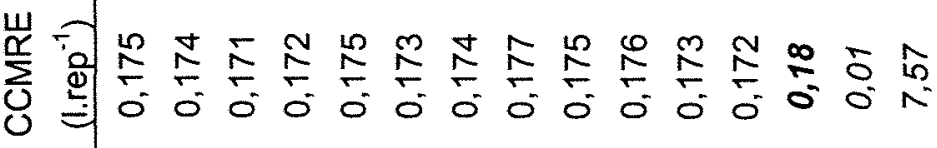

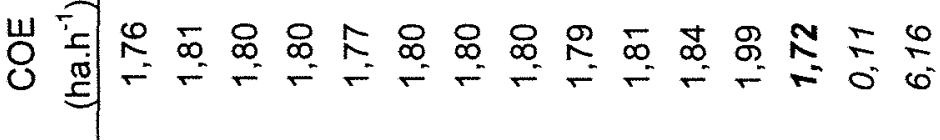

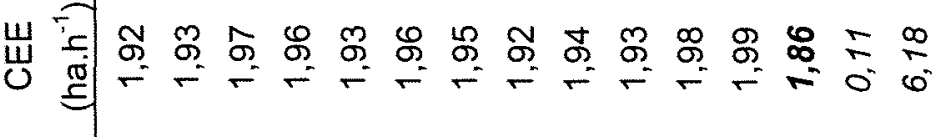

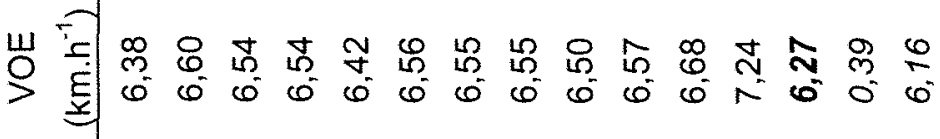

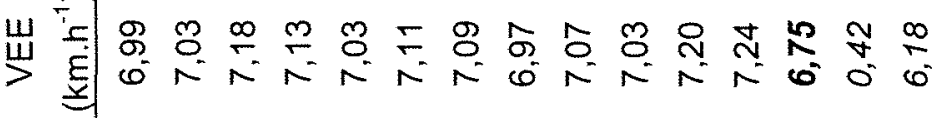

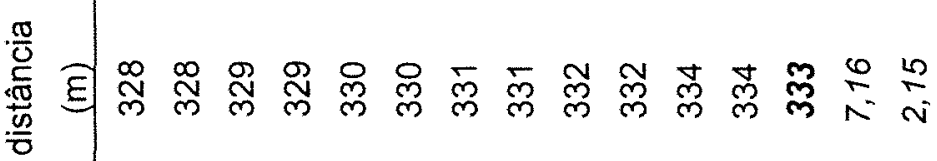

产

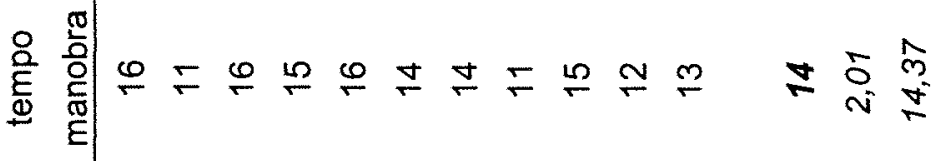

递离

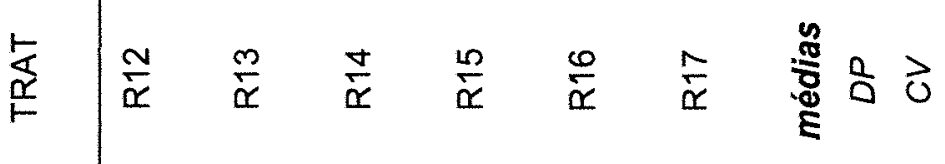




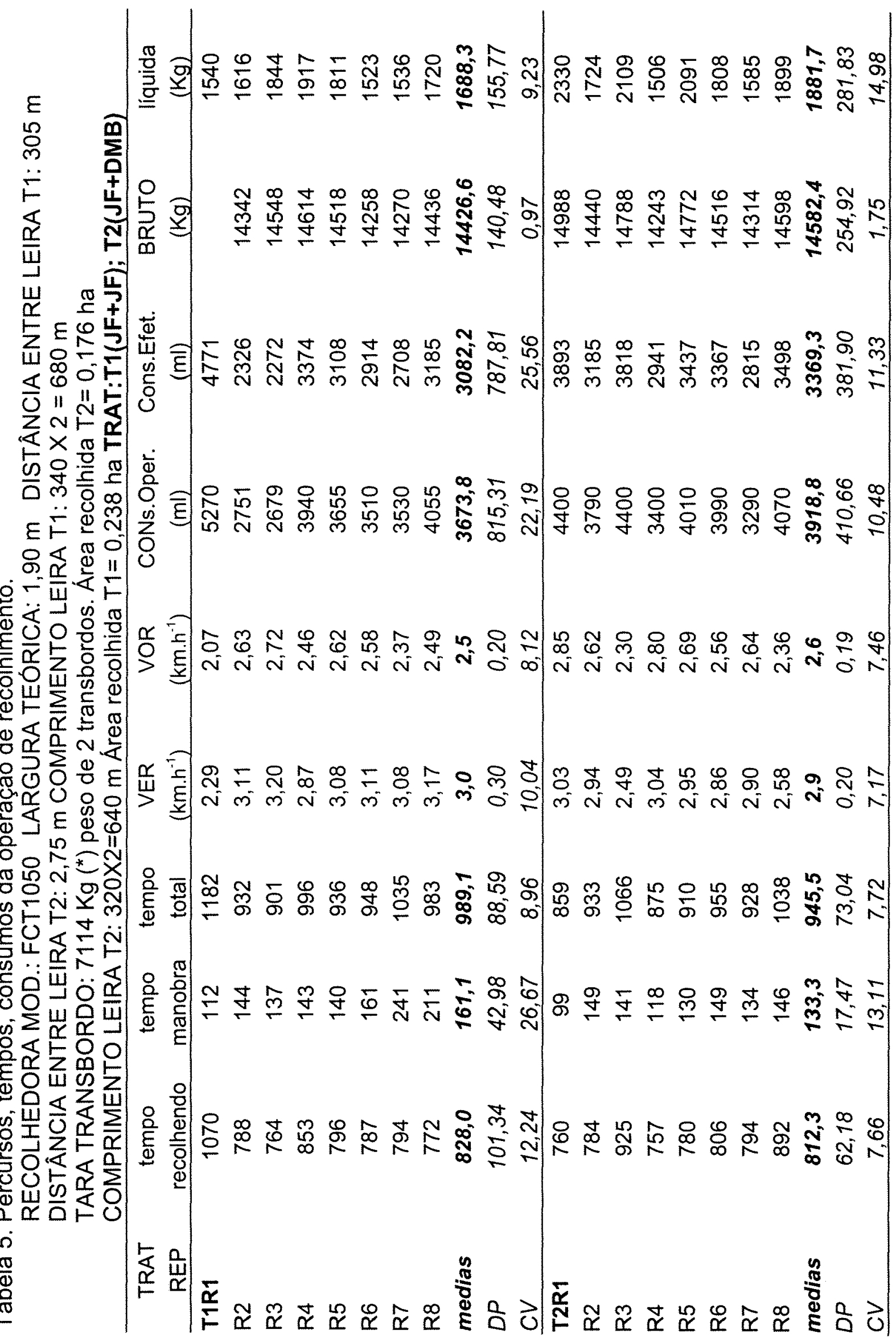




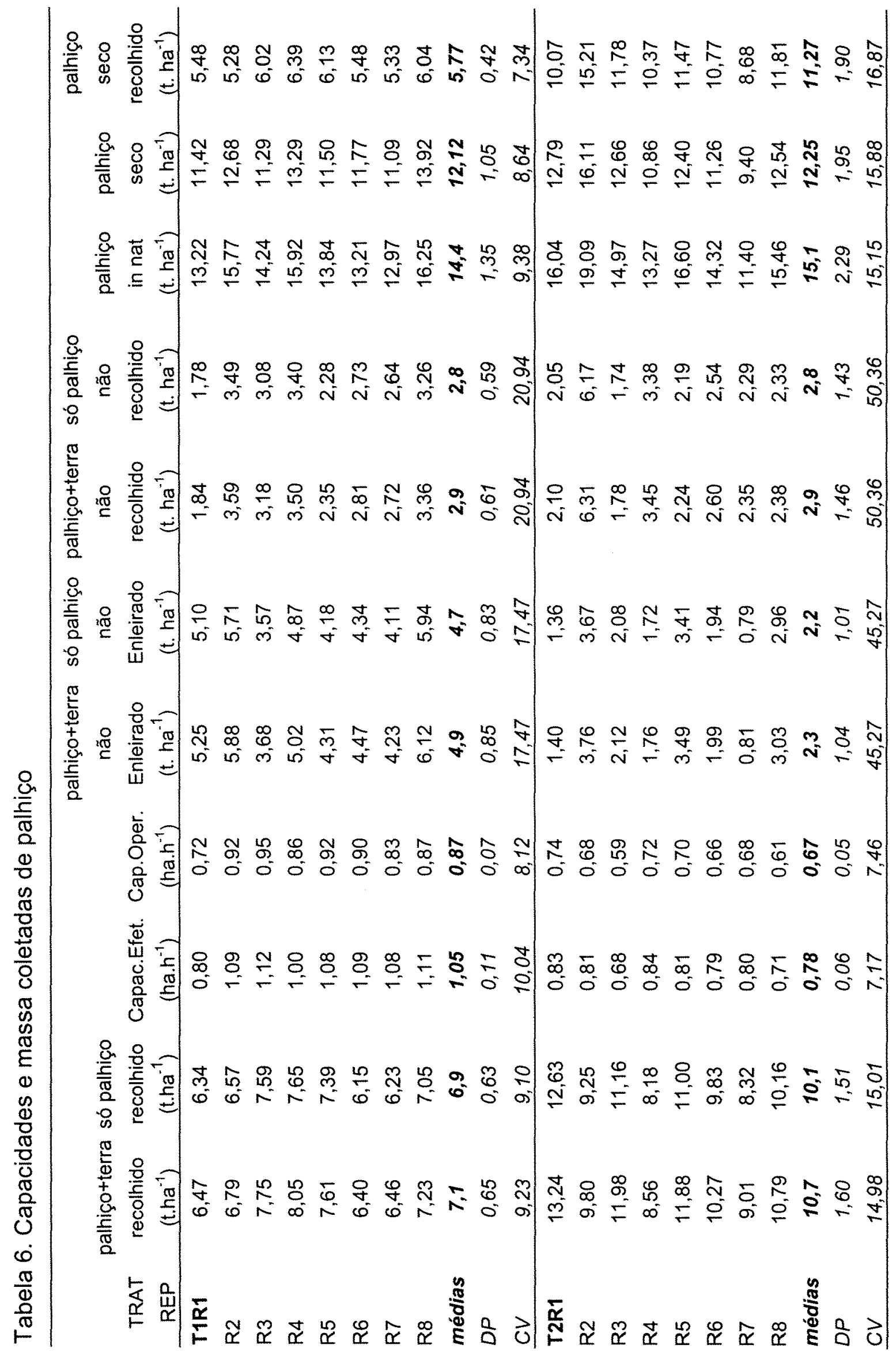

